Portland State University

PDXScholar

$1-1-1981$

\title{
Citizen advocacy groups, an intervention strategy: a case study of the Community Coalition for School Integration in Portland, Oregon
}

Patricia J. Rumer

Portland State University

Follow this and additional works at: https://pdxscholar.library.pdx.edu/open_access_etds Let us know how access to this document benefits you.

\section{Recommended Citation}

Rumer, Patricia J., "Citizen advocacy groups, an intervention strategy: a case study of the Community Coalition for School Integration in Portland, Oregon" (1981). Dissertations and Theses. Paper 475. https://doi.org/10.15760/etd.475

This Dissertation is brought to you for free and open access. It has been accepted for inclusion in Dissertations and Theses by an authorized administrator of PDXScholar. Please contact us if we can make this document more accessible: pdxscholar@pdx.edu. 


\title{
CITIZEN ADVOCACY GROUPS - IST INTERVENTION STRATEGY:
}

A CASE STUDY OF TLE COMPUNITY COALITION FOR SCHOOL INTEGRATION IN PORTLAND, OREGON

\author{
by \\ PATRICIA J. FUMER
}

A thesis submitted in partial fulfillment of the requirements for the degree of

\author{
DOCTOR OF PHILOSOPHY \\ in \\ URBAN STUDIES
}

\author{
Portland State University \\ Patricia Rumer (C) 1981
}


TO THE OFFICE OF GRADUATE STUDIES AND RESEARCH:

The members of the Committee approve the dissertation of Patricia J. Rumer presented
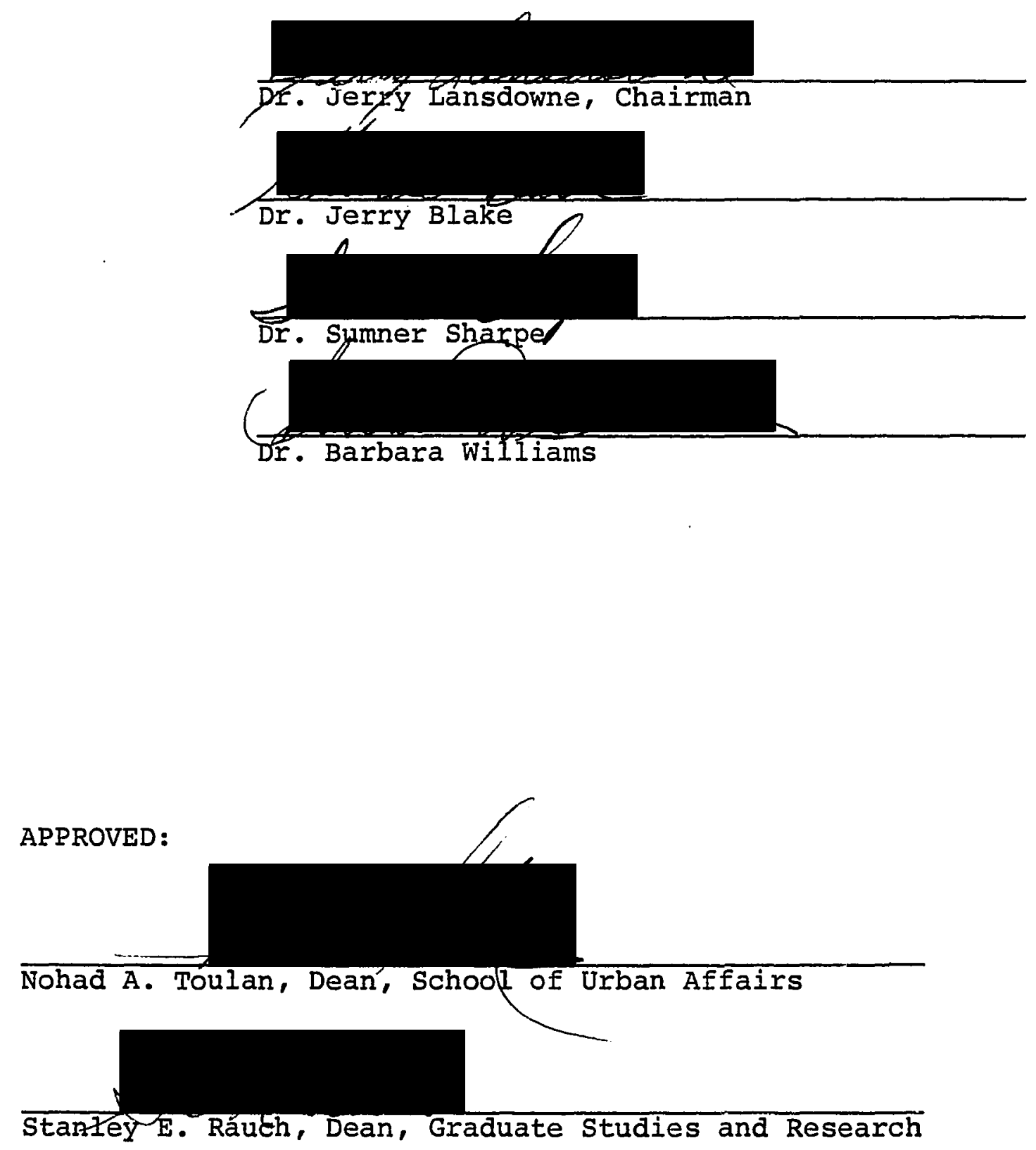
AN ABSTRACT OF THE DISSERTATION OF Patricia $J$. Rumer for the Doctor of Philosophy in Urban Studies presented April 23, 1981 .

Title: Citizen Advocacy Groups - An Intervention Strategy: A Case Study of the Community Coalition for School Integration in Portland, Oregon.

APPROVED BY MEMBERS OF THE DISSERTATION COMMITTEE:
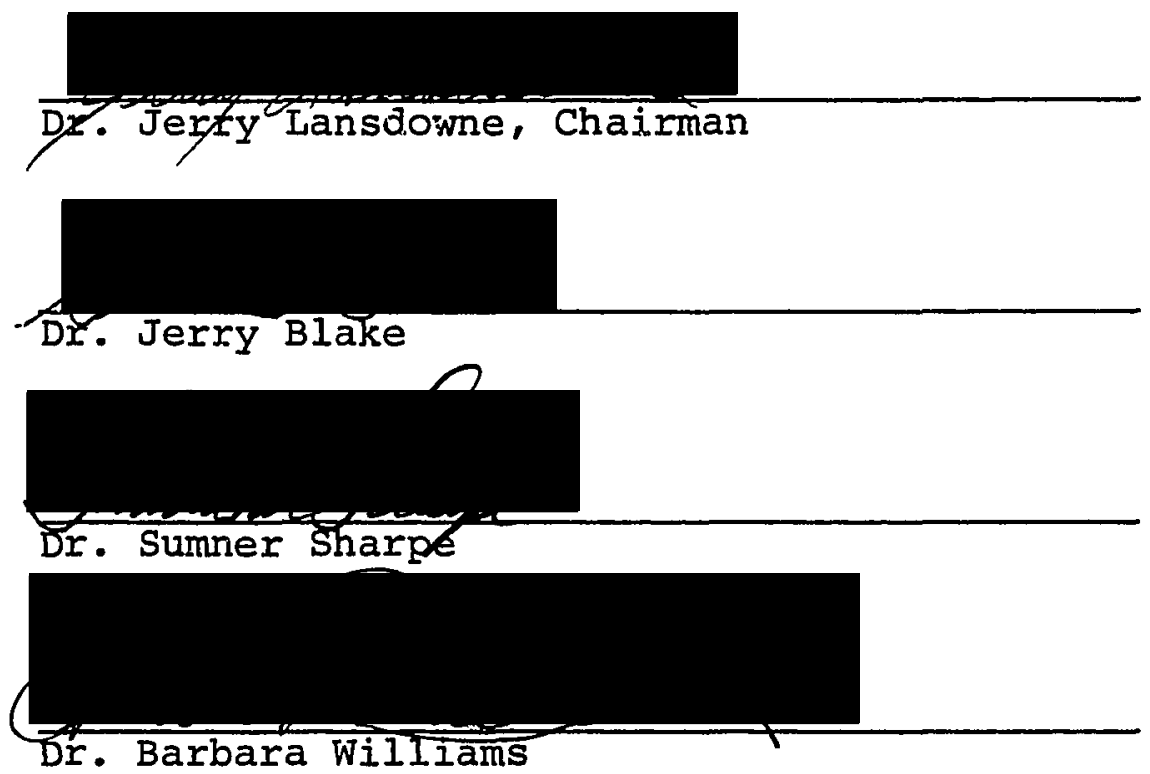

This dissertation focused on citizen advocacy groups as an intervention strategy for affecting change in the policy process. The analysis is of a specific intervention in school desegregation policy by a citizen advocacy group. The purpose of this research was to identify the conditions 
under which a citizen advocacy group can intervene; the constraints to a successful intervention; and the attributes of a successful intervention.

The case study was of the Community Coalition for School Integration, a citizen advocacy group which existed in Portland, Oregon betwsen 1977 and 1980. A multi-method approach was used. It involved fifty interviews with members of the Coalition, school administration, school board and the media. In addition, historical and document analysis of secondary data and extensive literature review was done. The theoretical framework guiding this research was Iannaccone's dissatisfaction theory of governance, DIS/ID/STO/OS. DIS is evidence of community changed dissatisfaction reflected in voting behavior leading next to incumbent school board member defeat (ID) followed within two years by involuntary superintendent turnover (STO) and outside succession (OS). Rothman's (1968) models of community organization practice were used to analyze the intervention of the coalition.

The findings do confirm the DIS/ID/STO/OS theory of governance, but also suggest that community intervention is an intervening variable between the stage of dissatisfaction and incumbent defeat. The analysis of the intervention identifies six conditions necessary for community intervention: timeliness of the issue, financial resources, leadership, organizational support, staff, and media coverage. 
The major constrainis were the lack of trust between the policy-making body and the citizen advocacy groups, and the political environment of the community. Attributes of successful intervention were: focused advocacy, multiple intervention strategies, and permanency of the organization. The impact of the citizen advocacy group's intervention is discussed, as are recommendations for future research. 


\section{ACKNOWTIEDGMENTS}

This dissertation describes the process of policy intervention by a citizen advocacy group. The cooperation of the Community Coalitior for School Integration made this study possible. I wish to thank the members of the coalition who shared their experiences with me. Also, my appreciation to school board members, school district staff, and members of the media who were interviewed.

I appreciate the support of my dissertation committee over this past year and Dan Davis for the fellowship assistance during the proposal and data collection stage of the dissertation.

Finally, this dissertation was made possible through the strong support of my friends and family, especially my father who encouraged me to pursue doctoral studies. 
TABLE OF CONTENTS

PAGE

ACKNOWLEDGMENTS $\ldots \ldots \ldots \ldots \ldots \ldots \ldots \ldots \ldots \ldots \ldots \ldots \ldots \ldots \ldots \ldots$

IIST OF FIGURES $\ldots \ldots \ldots \ldots \ldots \ldots \ldots \ldots \ldots \ldots \ldots \ldots \ldots \ldots$

INTRODUCTION $\ldots \ldots \ldots \ldots \ldots \ldots \ldots \ldots \ldots \ldots \ldots \ldots \ldots \ldots \ldots \ldots$

CHAPTER

I REVIEW OF THE IITERATURE .............. 3

Citizen Participation in Education ...... 3

Education Professionals, School

Boards and School Policy ............ 8

Federal Government, the Courts and School Desegregation ............. 11

The Policy Process ................ 17

II RESERRCH DESIGN AND METHODOLOGY .......... 27

Methodology ..................... 28

Method of Gathering Data ............ 31

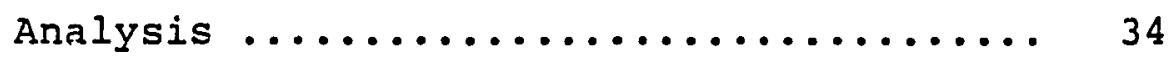

III HISTORICAL ANALYSIS OF SCHOOL DESEGREGATION POLICY, PORTLAND, OREGON ................ 38

"De Facto Segregation": 1954-1965 ....... 38

Community Response to Desegregation Plan: $1965-1970 \ldots \ldots \ldots \ldots \ldots \ldots \ldots . \ldots . \ldots 42$

Desegregation Plan \#2: "Schools for the Seventies" ............... 48 
Implementation of Schools for the Seventies Plan: 1970-1977 ...........

Analysis of Desegregation Policy--

Portland Style: 1962-1977 ........... 60

IV COMMUNITY DISSATISFACTION WITH THE

DESEGREGATION POLICY .................. 64

Community Reaction ............... 65

Factors Contributing to Coimunity

Dissatisfaction ................ 73

V FNALYSIS OF THE POLICY INTERVENTION ....... 80

Chronology of Coalition Activities ..... 88

Description of Coalition Membership ..... 94

Factors Shaping Community Organization

Intervention (Rothman, 1968) ........ 100

VI IMPACT OF THE POIICY INTERVENTION ........ 137

Initial Impact of Coalition Report ...... 139

Long-Term Impact ................. 151

VII FINDINGS AND CONCLUSIONS .............. 165

Dissatisfaction Theory of Governance .... 165

Theoretical Implications for Policy Intervention By Citizen Advocacy

Groups ...................... 177

Areas for Future Research ........... 182

SOURCES CONSULTED ........................ 186

APPENDICES .............................. 197

A. Interview Guide .................... 197

B. Informed Consent Release .............. 200

c. Key Interview Questions ............... 201 
D. Chronology of Coalition Activities: 1977-1979 ....................... 202

E. "What is the Coalition?" June, $1978 \ldots . . .203$ 


\section{LIST OF FIGURES}

FIGURE

PAGE

1. Changes in existing policy ...............

2. Models of community organization practice:

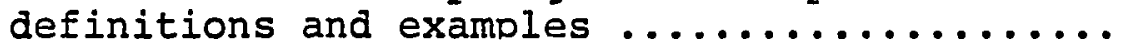

3. Theory of dissatisfaction with social action/ social reform models of community

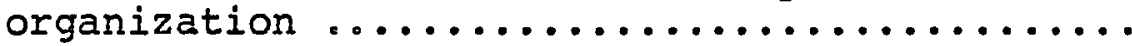

4. Portland public schools boundaries map elementary and high schools ..............

5. Comparison of the community coalition with two models of community organization practice (Rothman, 1968)

6. Policy impact of Coalition ............... 152 


\section{INTRODUCTION}

The purpose of this study is to analyze a specific intervention in school desegregation policy by a citizen advocacy group. Social science research has investigated citizen participation, the public policy process and school desegregation as separate phenomena in a democratic political system. Citizen participation has been a focus of research in the fields of community organization (Alinsky, 1971; Rothman, 1968), political science (Donovan, 1973; Moynihan, 1969), planning (Arnstein, 1969; Hallman, 1968), education (Davies, 1974; Iannaccone and Lutz, 1978; Gittell, 1979), and the politics of school desegregation in political science (Crain, 1968; Levy, 1971; Kirby et al., 1973).

While these elements have been identified as significant to an understanding of the democratic policy process, they have not been dealt with in an integrated fashion. The study of the public policy process requires an interdisciplinary approach to understand how policies are initiated, enacted, implemented, and evaluated (Dror, 1971; Dye, 1978; MacRae, 1976; Wildavsky, 1979). A synthesis of these critical elements as applied to an actual contemporary issue should provide a more complete understanding of the policy process, intervention, and change. Specifically, 
it will identify the conditions under which a citizen advocacy group can intervene to affect a change in policy; the constraints to a successful intervention; and the attributes of a successful intervention.

This study begins with a review of these various

fields of study: citizen participation, school desegregation, and the policy process. Chapter II describes the research design and methodology. Chapter III provides the historical analysis of school desegregation policy in Portland, Oregon from 1962 to 1977. Chapter IV analyzes the development of community dissatisfaction with the school desegregation folicy. Chapter $V$ contains an analysis of the citizen advocacy group and its intervention strategies, developed through the application of Rothman's (1968) models of community organization practice. Chapter VI assesses the impact of the intervention on the policy. Chapter VII concludes with a discussion of the findings and their implications for developing a theory of educational policy intervention by advocacy groups. 


\section{CHAPTER I}

\section{REVIEW OF THE IITERATURE}

\section{Citizen Participation in Education}

Citizen participation in federal programs became a major factor with the passage of the Economic Opportunity Act of 1964 which mandates the "maximum feasible participation" of the poor in planning and administering the various programs which comprised the community action component of the federal anti-poverty effort. One of the foundations of America's democratic society is that citizens have a right to participate in the political, economic, and social life of that society. Part of the historical struggles in political participation in the United States has been that of women and blacks to gain the right to vote. The significance of the Economic Opportunity Act was that it targeted a specific population for inclusion in the policy process (Donovan, 1973). The Economic Opportunity Act stated that "community action programs should be developed, conducted, and administered with the maximum feasible participation of residents of the areas and group to be served" (U.S., Congress, Economic Opportunity Act; Pub. L. 88-452, 88th Cong., 2d sess. 1964 ). The federal mandate of citizen participation was a 
result of several historical forces at work in the United States during the 1950s and 1960s: the Civil Rights movement with its focus on voting rights for blacks in the South (Carmichael and Hanilton, 1968); the discovery of the economic and social problems of big city ghettos by private foundations (Spiegel, 1969); the federal government's experience with poor communities in its urban renewal programs (Bellush and Hausknecht, 1967); and the implementation of new social work practices directed at organizing and mobilizing the poor (Cloward and Ohlin, 1960; Marris and Rein, 1967; Moynihan, 1969). All of these forces influenced the federal government in its decision to involve the poor in the War on Poverty.

Citizen participation in education began with the federal programs of Head Start, Follow Through and Title I of the Elementary and Secondary Education Act, which mandated citizen involvement through the establishment of citizen advisory committees and the employment of local residents (Fantini, 1970). Since then, institutionalized citizen participation in federally supported education programs has grown to one million citizens who are members of local school councils and advisory committees in the United States (Davies, 1978).

In the years since the passage of the Economic Opportunity Act, citizen participation has expanded in a series of federal government programs, such as Model Cities and 
Community Block Development Grants. Participation has grown beyond the poor and minority communities to include all citizens.

One of the persistent difficulties since the call for "maximum feasible participation" was a clear definition of citizen participa:ion (Donovan, 1973; Moynihan, 1369). In order to clarify some of the issues involved in citizen participation, Sherry Arnstein (1969) developed a typology of citizen participation in the "form of a ladder, each rung corresponding to a degree of citizen's power in determining plans or programs" (Davies, 1974, p. 12). Participation ranges on a continuum from the lowest rungs which represent token or superficial participation to the highest rungs where there is substantial citizen control through a transfer of decision-making power (Arnstein, 1969). The question of how citizens should participate or to what degree should they decide policy, has been sharply debated among advocates of citizen participation. Most citizens participate in federal programs at the lowest rungs of the ladder in an "informing" and "consultation" capacity--meaning that they may be heard and their advice considered, but they lack the power to ensure that their views will be heeded (Arnstein, 1969). Although support for substantial citizen control exists, there is no evidence that a significant transfer of decision-making power has occurred. Arnstein (1969) notes that "community action 
programs are characterized by empty ritual of participation with no redistributicn of power occurring to the poor" (p. 216).

Researchers evaluating citizen participation in education found little or no impact on redistribution of decision-making power. One report concluded:

A genuine commitment to community participation requires extensive attention to structures at the individual school and district level which encourage and support direct community roles in the selection and review of personnel, the determination of priorities in the allocation of resources, and the development of educational options.

(Gittell, 1979, p. 49)

Don Davies, the director of a three-year study of community organizations for the National Institute of Education, said that "despite new organizations and impressive statistics, little power has been transferred to parents and citizens" (1978, p. 12)

Supporters of the "insormation and consultation" role for citizens in education point to the number of citizens active on committees and as school volunteers. Parents work in Parent-Teacher Associations (PTA) and volunteer in their children's classes. Citizens vote in school board elections and on school tax levies. Some citizens serve on the school board, which can be an elected or appointive position. At present, there are 100,000 school board members in the United States (Salisbury, 1980).

The issue of the nature of the impact of citizen participation on federal programs and local school policies 
is unresolved. Advocates of substantial citizen control although recognizing that redistribution of power has not occurred, still push for more meaningful citizen participation in the policy process. Others argue that citizens are already active on citizen advisory committees, but they lack evidence as to the significance of that involvement (Gittell, 1979). While the debate over the nature and purpose of citizen participation continues, federally mandated citizen participation remains.

Two new forms of citizen participation that have appeared since 1970 are "child advocacy groups such as New York's Advocates for Children and the Massachusetts Advocacy Center, and grassroots neighborhood associations such as the South Central Planning Council in Los Angeles" (Davies, 1978, p. 12). These new advocacy groups are determined to change or modify school practices and policy in order to improve educational opportunity and school performance by intervention in the decision-making process (Davies, 1978; Gittel1, 1979; Grant, 1979).

Although the numbers of citizens participating in school issues has grown in the past decade, so has the influence of other participants in the educational policy process. The power of education professionals has increased, the role of the school board has changed, and federal government programs and court decisions have impacted school policy. 


\section{Education Professionals, School Boards and School Policy}

The public policy process at the local school district involves a series of participants: the school board, school administration and teachers, and various publics. School boards have the legal authority to establish educational policy for local school districts (zeigler and Jennings, 1974). Education professionals operate the schools--administrators, teachers, aides, counselors, and support staff.

At the beginning of the public school movement in the United States, lay committees of citizens established the curriculum, hired the teachers, and raised the money to operate the schools (Katz, 1975). During the period 18501890 schools moved away from local community control to an increasing pattern of centralization. As one educational historian commented:

Thus, the growth of stronger central school boards and appointment of superintendents meant the decline of Jeffersonian "small unit" democracy and the rise of a meritocracy of city-wide policy-makers and of highly paid city school administrators. (Cronin, 1973, p. 591

Since the turn of the century, the role of the education professional has continued to expand. There are several indicators of this shift in power from school boards to the education professionals. First, teachers have organized and through collective bargaining now influence many aspects of educational policy (Davies, 1978; Fantini, 1970; Gittell 
et al., 1979). Second, school superintendents also have a strong influence on educational policy. In theory, the school board establishes policy, but in practice, education professsionals control policy "because institutional and behavioral norms of school governance promote the authority of professionals" (Tucker and Zeigler, 1978, p. 19). The education professionals are the professional managers who implement the policy decisions and the school board is the "citizen legislative body with representative functions" (Tucker and zeigler, 1978, p. 19).

Third, the school board is composed of lay volunteers, who may be elected or appointed. For most, board membership is a part-time job. Most school boards do not have their own staff and thus depend on the administration. Twothirds of the school boards delegate the agenda-setting function to the administration. Tucker and Zeigler's study (1978) of school boards found that administrative recommendations were adopted in ninety-nine percent of the decisions made by formal vote and that nearly eight-five percent of board votes were unanimous (p. 20). However, lccal school boards continue to exercise control over most routine and episodic decisions, such as personnel matters (e.g., teacher contracts) and economic concerns (e.g., bond issues, school budgets and buildings) (Iannaccone and Cistone, 1974). As discussed in the section on citizen participation, federally mandated programs desire to redistribute decision- 
making power to citizens. The next question is: do citizens influence the school board through voting behavior? The answer is that very few citizens vote in school board elections. In a recent study of school boards, it was found that school elections have a low voter turnout with only fifteen to thirty percent of those eligible voting (Tucker and Zeigler, 1978). Those that do vcte are individuals with greater than average wealth, education and social and occupational status. Also, in many states school board elections are held independent of state primary and general elections.

Tucker and Zeigler (1978) conclude that although citizens elect the board and have at least the potential for influence, in reality the citizens enter the process after the issue has been defined.

The public does not exercise influence over school district officials and rarely achieve policy goals as a direct result of their participation. The reform goal of insulating school district governance from mass citizen participation and influence has been well met. (p. 23)

In summary, education professional exercise the most influence over educational policy, followed by the school board which continues to exercise influence over routine and episodic decisions. Citizens, according to Tucker and Zeigler (1978) exercise the least amount of influence. 


\section{Federal Government, the Courts} and School Desegregation

The federal mandate of citizen participation created citizen involvement in a variety of education programs. Although federal education programs "provide on the average less than eight percent of the cost of running local schools" (Davies, 1978, p. 12), they shape policies through federal requirements regarding desegregation, the handicapped and sex equity which have impact on entire school districts. On the issue of school desegregation the federal courts and government also have given new legitimacy to citizen participation.

Citizen groups in desegregating cities have participated in developing desegregation plans, mobilized public support, participated in carrying out the plan, monitored and reported on compliance, performed child advocacy and protection services, and have been involved in educational improvement. (Davies, 1978, p. 12)

\section{Background on School Desegregation}

At the judicial level, the Supreme Court's landmark decision in the 1954 Brown vs. Board of Education ruling declared that separate educational facilities based on race are inherently unequal.

To separate them [black children] from others of similar age and qualification solely because of their race generates a feeling of inferiority as to their status in the community ...

(347 U.S. 483)

Early targets for desegregation were Southern districts 
which ran dual systems for blacks and whites. The South's schools were de jure segregation, segregation which exists as a result of some type of government action. Usually it was a result of school board policies and practices. As the courts looked at northern school districts, cases were brought against school systems characterized by de facto segregation, segregation which existed in fact, but was not traceable to or resulting from direct government action. More recentlȳ, the courts have become concerned about racially isolated schools and school districts. Racial isolation refers to schools or districts where a majority of one racial minority predominates, even if this racial imbalance results from residential patterns combined with neighborhood schools. Many state and federal courts ane ruling against racial imbalance so that no school in a system may depart substantially from the district-wide racial proportions (Pascal, 1977).

However, some large cities face district-wide segregation since greater than eighty percent of their school population are minority students. The supreme court has been unwilling to "mandate a school desegregation plan that crosses the political or legal boundaries of a school district" (Rossell, 1978, p. 134). This decision has set limits on large urban school district's options for desegregation. 
In the absence of a national plan to desegregate all school districts, individuals can choose to comply or evade the local desegregation plan simply by moving outside the boundaries of the school system or enrolling in a private school. (Rossell, 1978, p. 134)

In addition to the courts, Congress passed legislation (Title IV of the Civil Rights Act of 1964) which authorized federal assistance to school boards, school districts, and other governmental units legally responsible for the operation of pubic schools, to aid those bodies in their desegregation efforts. The then Department of Health, Education and Welfare (now the Department of Education) had the primary responsibility for ensuring equal educational opportunity for all students in public school:s.

The federal government's principal tool to enforce desegregation of elementary and secondary schools is Title VI of the Civil Rights Act of 1964.* The office of Civil Rights is responsible for monitoring federally-funded public elementary and secondary school districts, eliminating all vestiges of unlawful discrimination, and ensuring equal educational opportunity. (U.S. Commission on Civil Rights, 1979 , p. 14)

The Office of Civil Rights monitors the progress of desegregation in both court-ordered and board-ordered school desegregation plans.

Various options are available to communities on ways

*Title VI of the Civil Rights Act of 1964 prohibits discrimination on the basis of race, color, or national origin by recipients of Federal funds. If a Federal agency should find illegal discrimination as a result of a hearing, it is authorized to terminate or refuse funding or use other legal means to ensure compliance with the provision of Title VI. (U.S. Commission on Civil Rights, 1979, p. 8) 
to implement desegregation, whether to remedy de jure or de facto segregation. Desegregation may be implemented as a result of a court order or a board decision. The desegregation plan may be either a voluntary or mandatory plan. Christine Rossell (1978) in a recent article on school desegregation defines the various terms.

Terms such as mandatory and voluntary desegregation
are often confused with court-ordered and board-
ordered desegregation. The terms mandatory and
voluntary refer to the degree of parental choice,
whereas the terms court-ordered and board-ordered
refer to the source of the order to desegregate.
Court-ordered plans can be either mandatory (as
in Boston and Pasadena) or voluntary (as in Mil-
waukie, Houston and San Diego). In the latter
plans, the courts have ruled that the school dis-
tricts have fulfilled their constitutional obliga-
tions by implementing a voluntary busing plan,
although such plans rarely result in more than a
ten point reduction in segregation. Board-ordered
plans can also be mandatory (as in Berkeley and
Seattle) or voluntary. The latter are typically
called minority to majority transfer programs.
(Rossell, 1978, p. l60).

Patterns in Northern School Desegregation

In a survey of ninety-one northern cities experiencing school desegregation between 1963 and 1969, Kirby, Harris, Crain, and Rossell (1973) found the first demand for school desegregation was made in $1963-64$ by local chapters of the National Association for the Advancement of Colored People (NAACP) concerning "perceived inequities in the entire school system" (Kirby et al., 1973, p. 23). The group that made the demand wanted more than procedural or symbolic actions 
on the part of the school system. They demanded that "white students and teachers participate in improved education for Negroes" (Kirby et al., 1973, p. 23).

Seventy-five percent of the ninety-one cities surveyed responded that their school systems did nothing or took only symbolic or procedural actions in response to civil rights groups' demands (Kirby et al., 1973, p. 35). An example of a symbolic-procedural action was usually the appointment of a committee to study the problem. Fiftyfive percent of the ninety-one cities surveyed had school boards that decided to appoint a committee to study the problem (Kirby et al., 1973, p. 39).

The responses. . . suggest that school systems felt the problems were not of their own making, nor were the solutions their responsibility. School systems were not initiators or leaders in the school desegregation process. They had to be prodded. (Kirby et al., 1973, p. 37.)

Kirby attributes part of the lack of response to school districts' long tradition of assimilation, meaning that schools help to socialize or integrate immigrants into American society. The belief in assimilation is buttressed in the practice by a "color-blind" policy of treating all students equally. As a result of these beliefs, most northern school districts did not believe that theirs was a segregated school system, They responded to the demands of civil rights groups by saying that "their school was indeed desegregated. By this the school system meant that 
it was not supporting segregation or unequal education" (1973, p. 67).

Although pressure from civil rights groups, other minority organizations and white liberals produced some symbolic-procedural action, Kirby et al. (1973) found that

such pressure was less likely to bring about a busing program or the establishment of racial quotas --actions which are more administrative in nature. Integration actions require an ideological and philosophical commitment on the part of school system officials which, although not impervious to controversy and pressure, are not as vulnerable to it. (p. 50)

They conclude by identifying several factors as critical in those school districts where actual desegregation was implemented by the school system. They were: leadership of the superintendent, an involved mayor playing a "liberal" role, and the support of civic leaders. In contrast, the total amount of civil rights activity and white citizen opposition had very little impact on school desegregation decisions (1973, pp. 14-15). They concluded that very little desegregation actually occurred from the many programs initiated from $1966-68$ and that most desegregation in northern big cities häs happened since 1968 .

This concludes a brief review of the desegregation environment. As indicated earlier, however, there is a larger contexi within which change occurs and can be analyzed. It is to this policy process that we now turn. 
The Policy Process

The policy process concerns how decisions are made in a political system. Jones (1970) states that the policy process "suggests a highly relative and pluralistic decisionmaking system characterized by compromise, incrementalism, and continual adjustment" (p. 9). Lindblom (1968) views the policy process as an "extremely complex analytical and political process to which there is no beginning or end" (p. 4). Anderson (1975) defines policy process as "a purposive course of action followed by an actor or set of actors in dealing with a problem or matter of concern" (p. 3). For Dye (1978) public policy is the "description and explanation of the causes and consequences of government activity" (2. 5). He adds,

This involves a description of the content of public policy; an assessment of the impact of environmentai forces on the content of public policy; an analysis of the effect of various institutional arrangements and political processes on public policy; an inquiry into the consequences of various public policies for the political system; and an evaluation of the impact of public policies on society, in terms of both expected and unexpected consequences. (p. 5)

The key elements in these definitions of the policy process are action and change. One model, Jones' (1970), demonstrates how changes occur in existing policy, as well as how policy develops. The first stage in the policy process is identification of the problem to government. The second stage is the formulation of the policy to address the problem by government. The third stage is the adoption 
or legitimation, of the policy by government. The fourth stage is application, in which the governinent acts to implement a program. Then the fiftn stage is evaluation where someone or some group recommends changes of adjustments in the policy, which sets the stage for the process to modify itself, or to begin again. This process is not static nor linear, but is an evolving, fluid process. The dynamic of this model presented by Jones (Figure 1) indicates that after the evaluation stage, other issues may arise which cause the policy to be reformulated and for the process to repeat itself. Wildavsky (1979) describes the policy process as not so much problem solving, but problem succession. As Dye (1978) pointed out in his definition of the policy process, unexpected consequences of policies produce a demand for a new or revised policies in response to recently identified needs.

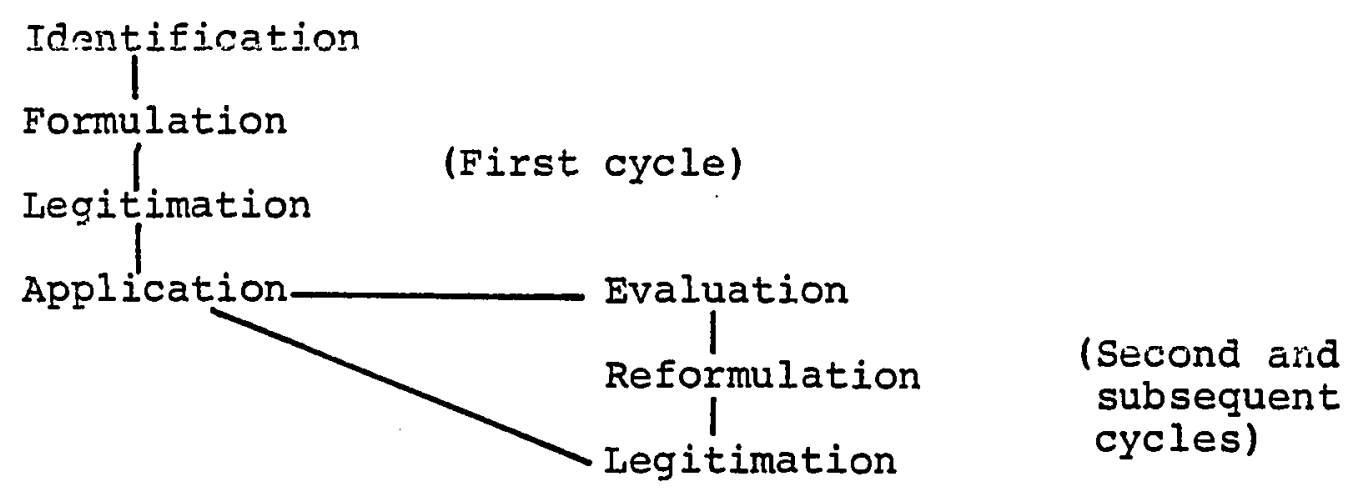

Figure 1. Changes in existing policy (Jones, 1970, p. 123 .

Although models provide a framework for policy analysis, 
policy is initiated, implemented, and evaluated in a political system. Policy impacts people, resources, and values. The policy process blends politics and planning. Planning implies a rational decision-making model. The rational decision-making model assumes that policy-makers have sufficient information.

This rationality assumes that the value preferences of a society as a whole can be known and weighted. It is not enough to know and weigh the values of some groups and not others. There must be a complete understanding of societal values. Rational policymaking also requires information about alternative policies, the predictive capacity to foresee accurately the consequences of alternate policies, and intelligence to calculate correctly the ratio of costs to benefits. Finally, rational policy making requires a decision-making system that facilitates rationality in policy formation. (Dye, 1978, p. 28)

policy making in a political ervironment must consider group interests, and political values, as well as financial resources, environmental factors, and structural constraints. One of the critics of the rational decision-making model, Charles Iindblom (1959), argues that the political system in the United States does not permit the rational model. He developed a different model to explain the policy process, the incremental model.

"Incrementalism views public policy as a continuation of past government activities with only incremental modifications" (Dye, 1978, p. 32). Policy makers accept current programs and agree to continue previous policies, for several reasons: (1) they lack the time and resources to pursue all alternative policies; (2) they accept present policies 
because the impact of new programs is unpredictable;

(3) previous investment in buildings or organizational structure is difficult to abandon; and (4) it is politically expedient. Small changes mean less conflict in the organization and more stability.

No one model explains all aspects of the policy process. The policy process, according to Wildavsky (1979), ideally should be a hybrid of $" 2 / 3$ politics and $1 / 3$ planning" (p. 125). He would combine the raticnai and incremental models for purposes of explaining the process. The Jones (1970) model incorporates the dynamic, changing aspects of the policy process. Critical factors in that process are: key actors, group interests, environmental factors, institutional system, economic resources, and societal values. Each factor plays a part in the policy process. The key actors are those people who are responsible for the policy, as well as those people who may oppose or seek to change the policy. Groups are affected by policy decisions. The previous sections identified the following groups active in education policy at the local level: PTAs, Citizen Advisory Committees, grass-roots neighborhood groups, public interest groups, and advocacy organizations. Additional grouks are business groups, taxpayers, and religious organizations. (Lutz and Iannaccone, 1969) Environmental factors include social, economic, and cultural issues which have the potential to affect the policy process. 
For example, economic fluctuations affect all policy decisions, but frequently policy makers have little control over these fluctuations. The institutional system is the organizational structure in which policy is made. An example from education demonstrates the interrelationships among governmental units. Local school districts have local autonomy and authority. However, they are connected to state and federal levels of government through joint administration of programs and federal guidelines over certain programs.

Economic resource refers to an important constraint on all policy-making. The allocation of resources limits program development and implementation. Policies can be established but programs never implemented, if the financial resources are reduced. Finally, societal values can serve as a constraint or motivating force on the policy process. Values such as freedom and equality differ in meaning to the public. People's attitudes towards these values lead to support of or opposition to a policy. Regarding school desegregation, some citizens have opposed desegregation programs on the basis of freedom of choice, while others have supported them on the basis of equality.

The Intervention Syrthesis

The focus of this study is on intervention in the policy process. Anderson's definition of the policy process 
(1975) as "purposive course of action followed by an actor or set of actors in dealing with a proble? or matter of concern." Intervention is a "purposive attempt to create a situation of change" (wiseman, 1979, p. 4). Much of policy analysis has focused on intervention strategies internal to organizations, i.e., organizational development. (Argyris, 1970; Chin and Benne, 1972). Littie research has focused on understanding the dymamics of policy intervention, from beginning to end. Wiseman (1979) calls for the study of standpoints and activities of those persons who do view society normatively, both the people involved in making social policy and those whose lives are touched in one form or another by policy interventions--with the clear goal of developing a theory of policy intervention. (p. 4)

The type of policy intervention to be examined in this study is intervertion by a citizen advocacy group, seeking to change a desegregation policy of the local school district. There are various strategies available to a citizen's group seeking a change in policy. Iannaccone's theory of dissatisfaction and Rothman's models of community organization practice will provide the theoretical and analytical framework to examine the intervention of the citizen's advocacy group.

The dissatisfaction theory of governance (Iannaccone,

1978) describes how voting behavior can change policy. Citizen dissatisfaction with educational policy has the "capacity to redirect local schcol government through changes in participating groups" (p. 131) 
Dissatisfaction (due to either the exhaustion of citizen satisfaction with a previous policy mandate or changes in citizen expectations and demands for education programs) leads to traumatic political change and the subsequent adaptation of the school organization. (Iannaccone, 1978, p. 130)

Dissatisfaction theory's premise is that a gap grows between the two aimensions of society, the governmental and the societal. The political system, over time, becomes closed to citizen demands. The governmental dimension moves towards "increased stability, perpetuation of the elite, and continuance of the same political ideology and related program values in schools" (Iannaccone, 1978, p. 130). At the same time, the community undergoes changes due to "demographic mobility, generational transitions, and educationally altered expectations" (Iannaccore, 1978, p. 130). Citizen dissatisfaction grows until public opposition forms which leads citizens to vote out the incumbents. In summary, DIS/ID/STO/OS, the dissatisfaction theory, seeks to explain the political change and adaptation of the school organization due to citizen dissatisfaction. DIS is evidence of community changed dissatisfaction reflect d in voting behavior leading next to incumbent school member defeat (ID) followed within two years by involuntary superintendent turnover (STO) and outside succession (OS).

The weakness of this theory rests in the assumption that a change in school board members will result in a policy redirection. School board elections are not partisan; many factors contribute to incumbent defeat. Analysis 
shows that very few voters participate in school board elections. This lack of participation raises questions as to the effectiveness of the vote and the political system in changing policies in local school districts.

\section{Intervention Strategy}

Rothman's models of community organization practice suggest more direct intervention strategies for citizens concerned about policy change. This comparative framework provides a basis for analysis of intervention by comminity organizations. Rothman provides four different models describing the practice of community organization (Figure 2).

A combination of the theory of dissatisfaction with a comparison of the social action and social reform modes of intervention provides the theoretical and analytical framework for this study. Figure 2 illustrates the composite framework to guide the analysis of the intervention strategies used by a citizen's advocacy group to change the desegregation policy of the Portland, Oregon school district. 
ORGANIZATION/

Individual

Examples

Peace Corps,

Vista

1. Locality Development which "presupposes that community change may be pursued optimally through broad participation of a wide spectrum of people at the local community level."

METRO (regional planning body)

2. Social Elanning where "rational, deliberatively planned, and controlled change has a central place in problemsolving."

Alinsky

3. Social Action "presupposes a disadvantaged population that needs to be organized, perhaps in alliance with others, in order to make adequate demands on the larger community for increased resources or treatment more in accordance with social justice or democracy."

League of Women Voters

4. Social Reform involves activity by a "group or coalition of interests which acts vigorously on behalf of some community segment which is at risk or disadvantaged."

Figure 2. Models of community organization practice: definitions and examples (Rothmar, 1968 in Zaltman, 1972, pp. 474-75, 488). 
Initial Decision by Legitimate Authority

TIME

Organized Central Elite and closed system

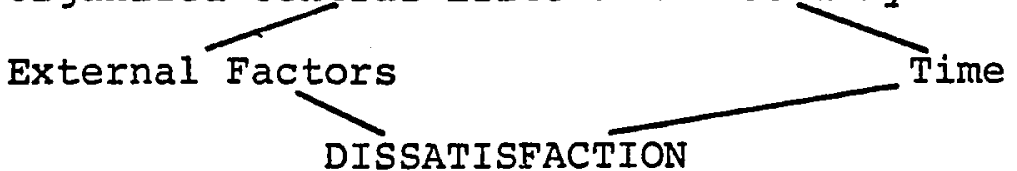

POLITICAL PROCESS

Formation of fübitic opposition

(INTERVENTION MODES)

- Voting

COMMUNITY ORGANIZATION

- Social action/social reform models

Figure 3. Theory of dissatisfaction with social action/social reform models of community organization.*

*Iaurence Iannaccone, "The Dissatisfaction Theory of Governance: Implications for Practice and Research," in Public Participation in Local School Districts: The Dissatisfaction Theory of Governance, eds. Laurence Iannaccone and Frank W. Lutz (Lexington, Mass.: Lexington Books, 1978).

Jack Rothman, "Three Models of Community Organization Practice," in Creating Social Change, eds. Gerald Zaltman, Philip Kotler, and Ira Kaufman (New York: Holt, Rinehart \& Winston, 1972). 
CHAPTER II

\section{RESEARCH DESIGN AND METHODOLOGY}

Innnaccone's dissatisfaction theory of governance and Rothman's models of community organization practice provide the theoretical framework to analyze the developmental process of citizen dissatisfaction and the policy intervention by the Community Coalition for School Integration in Portland, Oregon.

The purpose of this study is to test the adequacy of the Iannaccone and Rothman framework as an explanation of community intervention in the policy process. The findings also may contribute towards a theory of policy intervention. This study searches for an expianation of the citizen advocacy group's intervention in the Portland, Oregon school district's policy-making process regarding desegregation policies. The case study socuses on the developmental process of citizen dissatisfaction with the school desegregation policy. The dissatisfied citizens formed the Community Coalition for School Integration (CCSI), hereafter referred to as the Coalition, which then studied and made recommendations for changes in the district's desegregation policy. 
The problem statement of this study is:

How do citizens intervene in the policy process to address perceived inequities?

The questions that guide this research in addressing the problem statement follow:

1. What are the conditions under which a citizen's advocacy group can intervene to affect a change in the policy?

2. What are the constraints to successfui intervention?

3. What are the attributes of successful intervention?

\section{Methodology}

A naturalistic case study is the research methodology selected for this study of policy intervention by a community organization. Naturalistic research is the "investigation of phenomena within and in relation to their naturally occurring contexts" (Brandt, 1972, p. 7). This method was selected because it involves exploratory research, the searching out of issues in a natural situation. Its greatest power comes from the fact that this kind of research is relatively non-obtrusive, meaning that the researcher intrudes less in the reality of the world under study. Proponents of naturalist research (Brand, 1972; Guba, 1978; Wøbb et al., 1966) believe another strength lies in its heuristic approach to research problems. Researchers begin their study without preconceived 
ideas to collect data on a variety of factors and begin to form conclusions from a series of observations. This kind of research sees multiple-cause reality, not a single cause and effect relationship. Because the world is composed of many realities, this approach is closer in accurately representing the real world in its research.

The strengths of naturalistic research--its realism, its helristic quality, its multiple-reality approach--offset the disadvantages inherent in this research approach. Fiela work does not provide controls on people or the setting. Representativeness is a problem because the emphasis is on in-depth anaiysis of groups or a system. The field researcher does not select a sample ui individuals to interview, but obtains detailed data about particular people.

One answer to the problem of viidity in this kind of research, due to the lack of control or representativeness, is the use of triangulation. "Validity is provided by cross-checking different data sources and by testing perceptions against those of participants" (Guba, 1978, p. 63). Triangulation technique uses a multi-method approach to corroborate one set of data with another. Support for a multi-method approach is found with Webb et al. (1966):

Once a proposition has been confirmed by two or more independent measurement processes, the uncertainty of its interpretacion is greatly reduced. 
The most persuasive evidence comes through a triangulation of measurement procedures. (Webb et al., 1966, p. 3)

Researchers look for confirmability, an agreement among a variety of sources, before reaching a conclusion in their findings.

Other issues related to naturalistic research methods are: (1) Effects of interviews upon interviewees (Simon, 1969, p. 24): all the interviews and observations were conducted by the author. The research relies on the evidence of other data sources--newspapers, board minutes, Coalition documents, and subsequent events to correct any bias. (2) Observer bias: the research was not involved in the events of 1977-79 either through the Coalition or the school district. The researcher sought to include all perspectives on these events from persons supportive of the Coalition to persons critical of the intervention. (3) Variability over time: this is an ex-post-facto study. Individuals were interviewed approximately eighteen months after the intervention. A series of intervening events between September, 1979 (conclusion of study time) and Summer, 1980 (interviews conducted) may have affected people's interpretation of the Coalition's intervention. (See Conclusions, Chapter VII for further aiscussion.) Although some time had passed since the intervention, manv people were still involved in the desegregation issue. The subject was timely and people welcomed the opportunity to talk. Many of the 
interviews lasted more than one and one-half hours because of their interest in the topic.

In addition to triangulation techniques, this case study through its use of the Rothman models of community organization which is based on empirical evidence, will link the findings of this case study to the work of Rothman, as well as other citizen advocacy research.

\section{Method of Gathering Data}

The research bases for this study were historical and document analysis, interviews, and reviory of literature.

1. Historical/document analysis. A review of the Oregonian, Oregon Journal, and Portland Observer news articles on school desegregatjon between 1962 and 1977; documents such as the Schwab Committee report (1964), Model Cities Education report (1969), City Club report (1972), Schools for the City report (1975), and the U.S. Office of Civil Rights, School Desegregation in Portland (1977). In addition, minutes and tapes of critical school board meetings were examined. A review was made of coalition meeting minutes, memos, and working documents of the Research Committee, as well as Coalition correspondence. The Coalition files are located in the office of the Metropolitan Human Relations Commission.

2. Interviews. The interviews were focused and conducted during the summer and fall of 1980. An interview 
guide was used for all the Coalition interviews. (See Appendix A.l In addition to the interviews with Coalition, school board, school administration, and media persons, there were several interviews with people involved in previous community efforts to affect desegregation policy. They provided background information of the time period, $1962-1977$.

3. Review of literature. Extensive reading was completed in the fields of community organization, school desegregation, social change, educational governance, and urban politics in order to test the generalizability of the field work with empirical evidence from other research. The data for this case study were collected between March, 1980 and October, 1980. The interviews were conducted from June-September, 1980. The majority of interviews were taped. There were fifty interviews involving Coalition members, the school board, district administrators, the media, and Black United Front leaders. At the conclusion of each interview a brief description of the interview was written. There was also a review of each interview to look for themes or issues that the interviewee had identified. Some of the information gathered from one interview was used to verify or to obtain a reaction from another interviewee. The interviews with board and district administrators were oriented to their perspective on the coalition, their role in the sequence of events, their 
assessment of the impact of the Coalition and some general comments on the politics of education in Portland.

A similar procedure was followed during all interviews. Each individual was called. The purpose of the study was explained and they were asked for an appointment. There were two people who declined to be interviewed, a Coalition member and a school board member. Both cited reasons of time pressures and that their point of view could be gathered from other interviews. Two board members were unavailable for interviews; one had died and the other had moved out of state. All interviewees were guaranteed confidentiality and completed an informed consent release. (See Appendix B.)

Thirty-one Coalition members were interviewed, including two staff persons. The Coalition members were selected according to several criteria. First, all of the coalition leadership were selected, including the Committee Co-Chairs and the Task Coordinating Committee. Second, a broad perspective of members representing the racial, geographic, and philosophical diversity of the coalition were sought. Four key Coalition members were asked to identify people on the basis of the criteria. The group that was interviewed was selected from that list. The remaining criterion was the degree of involvement during the entire eighteen month period. (The only exceptions were Task Coordinating Committee members, some of whom were not active for the 
entire time period.)

Because individuals are not named in this study, documentation of the interviews has been coded. All interviews are cited by date. If more than one interview was conducted on the same date, then interviews are listed in alphabetical order, based on the order of the interviews. For example, interview $6 / 10 / 80$ a was the first interview of that day.

This is an ex-post-facto study. People were asked to analyze and discuss events with the hindsight they had gained from a year's distance from the issue. Some of the Coalition members were still very involved in desegregation issues, while others har " mpletely withdrawn from any kind of involvement.

\section{Analysis}

The analysis of documents, newspaper reports, Coalition, and school board materials took place between March, 1980 and December, 1980. The school district, through its Public Informatzon office, maintains a newsclipping file, board minutes, and tapes of the meetings. The coalition files contain all minutes of meetings, working papers for the research committee and final report, letters of membership, financial records, correspondence, questionnaires from participants in a series of Community Forums, desegregation research from other cities, and the interviews and 
data analysis on the Administrative Transfer Program, a study conducted by Oregon Attitudes, Inc. In addition, the oregon Historical Society supplied several taped interviews of: long-time activists in the black community, which were part of their Oral History Project. The most difficult information to obtain was history of blacks in Portland. Blacks in Oregon (1978) and The Growth of a City (1979) were consulted, but the most current and reliable resource is the black weekly newspaper, the Portland Observer (1970present).

The material was organized in two ways: (1) by time period and (2) by subject matter. The three time periods were: 1962-1977 (School Desegregation History in Portland); June, 1977-January, 1979 (Formation and Study Phase of Coalition); and January, 1979-September, 1979 (Aftermath and Impact Phase of the Coalition). The first time period was divided into subject areas of national civil rights and desegregation events; desegregation action in Portland; citizen groups active in desegregation policy, Model Cities and Citizens Committee for Better Schools; the two school desegregation plans, the Schwab Committee report and Schools for the 70s; and the state and federal changing role. Most of the data were gathered from newspapers, school documents: and citizen group primary source materials. Several informant interviews provided personal insights to this historical analysis. 
The second time period covered the community opposition to the Boise-King plan and the active period of the Coalition. The framework for analysis of this time period was the models of community organization practice (Rothman, 1968). The interviews provided the main body of data for this analysis. They were divided into Coalition members, school bcird, and school administration interviews. The Coalition members' questions were keyed to specific variables of the Rothman models (e.g., what strategies did the Coalition adopt to change the situation; what other strategies were considered?). These questions were keyed to the variables concerning basic change strategy and characteristic change tactics and techniques. (See Appendix C.)

The third time period, January, 1979-September, 1979 was the assessment of the impact of the policy intervention by the Coalition. Again, interviews were the main source of data with documents and newspaper articles being secondary. The subject $z^{\prime \prime a s}$ of this time period were the series of events: board rejection of the coalition recommendation on pairing, school board elections, Coalition visit to Seattle, Coalition/Board/District working committees, Office of Civil Rights ruling, Black United Front, appointment of Coalition Co-Chair to school board, proposed Black United Front boycott, and the August, 1980 short- and longterm resclutions on desegregation by the school board. 
Some of the issues were known at the beginning of the research while others emerged from the interviews and document analysis. The analysis is divided into two parts: first, an analysis of the intervention based on the practice variables of the Rothman models and second, an analysis of the impact of the intervention on the school system and community, based on two criteria--(1) changes in the formel rules of the educational system and educational practices affecting these children and (2) alteration of the network of activities at the federal, state, school district, and school levels that shape services to children (Moore, 1980). In summary, this study is based on a multi-method data base, using historical and document analysis, interviews and references to relevant empirical studies. The next chapter is a historical analysis of school desegregation policy in Portland, Oregon. 
CHAPTER III

\begin{abstract}
HISTORICAL ANALYSIS OF SCHOOL DESEGREGATION POLICY, PORTLAND, OREGON
\end{abstract}

"De Facto Segregation": 1954-1965

The Supreme Court called for an end to segregated schools in 1954, but not until 1965 did Portland public schools initiate a desegregation plan.

Prior to World War II, Portland had a small population of blacks. A study of Blacks in Oregon (1978) states:

Negroes were virtually banned from the state until the Second World War, at first by law and later by severe employment discrimination. During the war years, Portland experienced a much smaller migration than other west coast cities. (p. 38)

In $1940,2,565$ blacks lived in Oregon, with the majority residing in Portland. By 1950, the number had increased, accompanied by a pattern of residential segregation in Portland. In 1950, one half of Portland's 9,500 blacks were housed in census tracts \#22 and \#23 in the williams Avenue-Albina districts (MacColl, 1979). "A 1957 Report on the Negro in Portland: A Progress Report 1945-1957" said that "90\% of the realtors won't sell a house to a Negro in a white neighborhood" (City Club, 1957, p. 259). The concentration of blacks in some Portland schools was 
due, therefore, to discrimination in housing. The school board had adopted a "color blind" policy in 1954, when it stated that it had a policy of equal education and that it would take no action regarding segregation in Portland public schools (City Club, 1980).

\section{National Association for the Advancement} of Colored People (NAACP)

By 1960, Portland's black population had increased to 15,636 , with $78 \%$ of that population housed in the Albina area (Portland Public Schools, 1978). On April 20, 1962, the Oregon Journal's front page carried the headline, "Schools Here Hit as Racist." The NAACP had named Portland as one of the Western cities which segregated public schools. The local NAACP chapter in Portland asked the school board to end "de facto" segregation. A schonl official responded:

I am not sure what they class as a segregated school. In our policy we have not segregated children, we have put schools where children are and have established boundaries. (Oregon Journal, 4/20/62, p. 1)

The NAACP continued to pressure the school board. In October, 1962 the NAACP president said the only issue is "the fact of segregation. The Portland schools are not in compliance with the 1954 Supreme Court decision. The Board refuses to see the problem. There can be no solution until a problem is accepted" (Oregonian, 10/11/62, p. 32). The national NAACP organization had instructed all the local 
chapters to advise them if a iawsuit was necessary to bring about the end of segregated schools in their local community

In May, 1963, a 125-member Portland Citizens Committee on Racial Imbalance in the Public Schools urged the school board to undertake a study to "determine if a large number of the city's Negro elementary students are being harmed by being concentrated in de facto segregated schools" (Oregonian, $6 / 25 / 63$, p. 1). Neither the Oregonian or Oregon Journal's editorial pages were supportive of the NAACP or the citizens' committee, stating that the "proposed remedies could be worse than the situation now complained of" (Oregonian, 6/5/63, Editorial page).

\section{Race and Education Committee}

On Tune 25, 1963, the school board voted to appoint a committee of citizens to study and report back to the board by Janua:: 1, 1964 its findings on the city's racially imbalanced public schools (Oregoniar, $6 / 25 / 63$ ). The Committee on Race and Education (the Schwab committee, named after its chairman) concluded an eighteen-month study, reporting that Portland's schools were not providing children of all races with equal educational opportunity (1964). The guiding desegregation policy of the Portland Public Schools was established with the unanimous adoption of the report of the Committee on Race and Education in 
December, 1964. The school district became committed:

to take every reasonable step consistent with sound educational practice to encourage the integration of students of all races and to decrease the concentration of minority students in particular schools which occurs because of residential patterns. (Board statement, 12/64)

The recommendations of the Schwab committee became the first desegregation plan in the schouls and were implemented in 1965-66. The key recommendation established the Model School program, a compensatory education program in nine Albina schools. Elements of this program were lowered teacher-pupil ratio to 1:20, preschool programs, additional funds for field trips, and increased support personnel, i.e., teacher aides and community agents.

The Schwab committee endorsed the continuation of the district's neighborhood school concept. At the same time, it recommended the concept of a transfer program. The transfer program was an administrative program, with transportation provided for children selected by the district as well as for children whose parents desired the transfer on a space-available basis (Schwab, 1964). Although the Schwab committee stressed the goal of reducing segregation in Portland Public Schools through the Administrative Transfer Program, the major portion of the funds was spent on the compensatory education component, Model Schools (City CIub, 1972). 


\section{Community Response to Desegregation \\ Plan: 1965-1970}

The school board's adoption of the Schwab committee report did not satisfy the NAACP. The Portland NAACP chapter opposed the Model Schools approach as one sustaining racial isolation and imbalance (Oreannian. 11/16/64). Parents and citizen groups in Albina criticized the Model Schools approach for perpetuating segregation and the open enrollment pian (the Transfer Program), because both black and white parents could request transfer of their children. This was of major concern in the Jefferson High School attendance area, where it was feared white parents would send their students elsewhere, further decreasing the white population at that school (Oregonian, 4!7/65). Between 1964 and 1969 the Administrative Transfer Program expanded from 250 to 605 students, but "90\% of the Negroes were still confined to a handful of schools [in Albina]" loregonian, $3 / 1 / 66$, p. 13).

Model Cities Education Committee

During the period, 1964 and 1969, major education and civil rights legislation was enacted which increased funding sources and federal requirements for local school districts: OEO-War on Poverty (1964), Elementary and Secondary Education Act (1964), Civil Rights Act (1964), and then Model Cities (1967). These acts were viewed as 
attempts to change the social, economic, and educational opportunities of the disadvantaged in the United States. These programs also required citizen participation either through citizen advisory boards or as employees of the various programs. All Title I, ESEA programs required parent advisory committees (PAC), as did Head Start.

Portland received a planning grant in 1967-68 from the Department of Housing and Urban Development to develop proposals with the participation of citizens from the target area (essentially Albina) for programs that would revitalize the community (the Model Cities program). After a lengthy citizen involvement process, the Model Cities Education Comnittee submitted a plan to the Model Cities Oitizen Planning Board, which asked for some specific changes in education and made some definite recommendations to the school board. Specifically, Model Cities asked the school board to approve:

1. the establishment of a Community Education Liaison Board to review all policies related to schools in the Mociel Ci.ties area;

2. the hiring of 196 aides for Model Cities area schools;

3. the expansion of pre-school programs in Model Cities area;

4. the creation of a computer sciences program at Jefferson High School. (Model Cities Education Report, 1969, p. 18)

Tn addition, the entire report of the Model Cities Education Committee recommended a grade exchange plan, to further integration of the schools. This cross-busing plan would convert all Albina's schools into 7th-8th grade centers for 
all the children of the district. Model Cities children, $\mathrm{K}-6$, would be bused out to schools in the remainder of the city. It also called for the school board's commitment to total integration by 1970 and an end to the Model Schools program. The committee's final proposal was for the establistinent of an Experimental Learning Center in the Model Cities area, with an innovative life-learning program open to the entire district (Model Cities Education Report, 1969).

The Education Committee critized the district's approaches to community involvement in desegregation programs. On community involvement, the Education Committee charged that "citizens of the Model Cities neighborhoods have historically been left out when plans have been made directly affecting the education of their children" (Oregonian, $1 / 13 / 69$, p. 16). With regards to the Administrative Transfer Program, they stated:

It is the opinion of the committee that the oneway busing to the suburbs is highly inadequate because it has little effect on the segregated public schools.* (Model Cities report, 1969, p. 10)

The reaction of the school board to the Model Cities' request and recommendations was immediate. They labeled it as "vicious, irresponsible and inaccurate document" not a

*One-way busing to the suburbs began with the 1968-69 school year with about 100 students busing to Iake Oswego, Parkrose, and David Douglas school districts loregonian, $8 / 20 / 68$, p. 15$)$. 
"community effort, but the opinion of a few people" (Oregonian, $1 / 8 / 69$, p. 1). They saw it as an attack on the "very foundation upon which the Board had built its educational policies and programs." The Oregonian described the Board as "angry, stunned and hurt" over the accusation of "unresponsiveness to community needs and desires, particularly those of the Albina area" (Oregonian, 1/13/69, F. 16). Three days later, the school board said it could not act on the "four proposals" submitted by "odel Cities for approval for HUD funds "without implying endorsement of the entire education component" (Oregonian, 1/16/69, p. 35). The controversy ended in April, 1969 when the Model Cities Planning Board withdrew its request for a Citizens Education Liaison Board, rather than risk additional delays in application for federal funding.

The school bonrd then approved the other three proposals (teacher aides, preschool programs, and a computer science program at Jefferson High School). The Model Cities Education Committee, however, recommended that the Planning Board withdraw all four proposals, because "it is essential that parents play a policy rather than an advisory role in order to assure that schools reflect th needs of the community" (Oregonian, $4 / 2 / 69$, p. 19). That view of the role of the community was unacceptable to the board.

The school board would not endorse the citizens Education Liaison Board, which, as proposed, would function at a policy-making level. Policy making, 
as well as educational planning, is and will remain in the hands of the school board. (Oregonian, $4 / 2 / 69$, P. 19)

In the spring of 1969, when Model Cities Education Committee tried to implement their educational programs, Portland Public Schools board would not endorse their request for federal funds from HuD. The dilemma was that the school district did not need the money, but Model Cities needed the cooperation of the school district to effectively use their funds to help the Model Cities area population. The alternative was to start their own school district (Interview, 10/6/80). After this initial controversy with the school board, Model Cities never became involved in any major educational reform or planning effort, but channeled its funds to support school prograns, such as teacher aides in Model Cities area schools.

\section{Citizens Committee for Better Schools}

Within a few months of Model Cities' report (June, 1969), a second citizens' group emerged to urge the school board to work on integration of the schools. This Citizens Committee was formed from a local community action agency conference on urban issues. It began as an ad hoc task force on education in 1966. After extensive research on successful integration efforts nationwide, it sought support from various organizations for integration in Portland's schools. When they addressed the board in June, 1969, they 
had pledges of support from twenty-eight community groups. The committee was composed of white and black members representing such groups as churches, American Civil Liberties Union (ACLU), PTAs, and civil rights organizations.

The Citizens Committee urged the board "to work as fast as possible to reduce the Negro concentrations at about eight of the city's schools (50-90\%)" (Oregonian, $6 / 24 / 69$, p. 9). They also asked the board to "name a citizen group to study the possibilities for fuller and speedier integration, including the possible establishment of junior inighs and possibly busing of white students as well as black" (Oregonian, 6/24/69, p. 9).

One board member responded to the committee "It must be the board's first order of business to develop an integration plan and achieve it without delay" (Oregonian, $6 / 24 / 69$, p. 9). At that time, approximately 600 students were bused within the district and 200 students bused to the suburbs. All the students being bused were from predominantly, black schools. One perspective on the situation was that the board really did not want to have the community propose another approach to desegregation and used the fact of hiring of a new superintendent to delay action on the recommendations of the Citizens Committee. 


\section{Desegregation Plan \#2: "Schools for the Seventies"}

During early 1969, the school board was searching for a new superintendent. They were looking for someone who could address the "problems of growing militancy and unrest among students, teachers and citizens, plus outmoded management and buildings" (PPS, 1978, p. 10). The school board selected a superintendent whose main strengths were management and organization. He also had had experience in desegregation in his previous superintendency (Oregonian, $2 / 26 / 69)$.

The new superintendent submitted a master plan for Portland Public Schools to guide the future direction of the district. Its stated purpose was to achieve school integration. The key elements of the "Schools for the Seventies" plan were:

1. Reorganization and Decentralization: to divide the district into four administrative areas, each with a similar percentage of Black students;

2. Establishment of upper grade centers (middle schools) that would be racially desegregated;

3. Provision of Early Childhood Centers in racially isolated neighborhoods;

4. Limit of $25 \%$ minority students in middle and high schools. (Schools for the Seventies Plan, 1970) The public responded to the plan immediately. The 
Urban League gave it unanimous endorsement, followed by an endorsement from the Portland Association of Teachers (Oregonian, $1 / 23 / 70,1 / 24 / 70)$. The plan was introduced to the public on January 21, 1970. The Citizens Committee for Better Schools voiced several concerns about the plan. The plan called for the establishment of citizen advisory $00-$ mittees in each of the new area subdistricts. The Citizens Committee recommended that the advisory boaxds be composed of $50 \%$ black and $50 \%$ white; also, that the Area Citizen Advisory Committees (ACACs) be appointed through an independent committee, not by the school board. On the role of ACACs, the Citizens Committee for Better Schools said "We think the duties should be substantial, for we believe boards with no real voice would create more community dissatisfaction than no boards at all (Oregonian, 3/15/70, p. 34). The school district conducted a series of public meetings to elicit citizen comments on the "Schools for the 70 s" plan.

The plan was taken to the citizens in a series of four carefully planned public hearings scheduled in each of the four proposed areas of the city. The format for these hearings consisted of a narrated slide presentation, packets of information on the plan which were handed out to all participants, and a panel of Board members and the superintendent to answer questions. Detailed notes were taken of all citizen comments, although the notes were not consistently summarized for presentation in a workable way to the Board for its review. (Douglas, 1978 , p. 3)

The four hearings attracted approximately 2,000 people. 
The account in the Oregonian of February 3, 1970, following one of the public hearings, is representative of citizen concerns.

- Citizens ask if reorganization plan can go to a vote of the people instead of being decided by the school board.

- A spokesman from the Jefferson High School student body objected to any plan which would disrupt the student balance that was then prevailing at Jefferson (55\% white, $43 \%$ black, $2 \%$ Oriental).

- A citizen objected to the plan because it would break up Albina. 'split up the black forces.' He also wondered why busing couldn't occur both ways--of both black and white students. (Oregonian, $2 / 3 / 70$, p. 7)

A fifth public meeting was held in Albina in order to obtain citizen input from that area.

Dissatisfaction with the plan was expressed by several different groups. The Portland Federation of Teachers (PFT) stated it had no evidence yet of "commitment to teacher or community involvement in the planning of educational improvement and change prior to decision making by the school board" (Oregoniant: 3/5/70, p. 20). A survey by the PFT and several local organizations showed Albina residents opposing the plan by $2-1$. Of the 424 people surveyed, 60 percent opposed the way the plan divided Albina, opposed busing for racial integration, and opposed the 25 percent limit on black student attendance. Two-thirds of those surveyed wanted Jefferson High School maintained as a community school and not subject to the 25 percent black student limit (Douglas, 1978, p. 4). 
The chairman of the NAACP Education Committee labeled the "Schools for the 70s" plan "a scheme to weaken and frustrate black unity" and attacked the "racist philosophy of placing small numbers of blacks among whites." This long-time critic of school board policy on desegregation of Albina area schools described the previous efforts of the board:

The Race and Education Commission, which I call the racist and Negro Lackey Commission, was the forerunner of this plan. Model schools is just a subplantation to keep the blacks enslaved. (Oregonian, $3 / 16 / 70$, p. 15)

Some citizens also opposed the middle school plan because it would destroy neighborhood schools and result in children being bused away from their neighborhood.

A March 6, 1970 editorial in the oregonian said the public hearings had disclosed that there was "widespread apprehension that the superintendent's recommendations are a 'fait accompli' rather than a plan for Board approval, rejection or amendment" (Editorial page).

On March 23, 1970, the school board adopted the proposed reorganization plan. Except for changes regaraing the number of subdistricts and their boundaries (three instead of four), the plan remained largely unchanged from its original form. The board decided to appoint the ACAC members rather than follow the Citizens Committee recommendation of appointment by an independent committee. The board also reaffirmed its December, 1964 stand 
on its open enrollment policy, stating:

Any student may, upon request of his parents or guardian, transfer to and attend any other high school (or middle school) in the school district, provided that space exists, and provided further that such a transfer does not unduly increase the concentration of minority students in that high school or in the high school from which the student seeks to transfer. In order to avoid racial isolation of minority students, no high school or middle school sinall have a minority student enrollment which exceeds $25 \%$. (Board resolution No. $3553,3 / 23 / 701$

In a footrote to the resolution, the board stated that the $25 \%$ limit was drawn from "extensive studies and experience both in Portland and elsewhere as a desirable upper limit to minority concentration" (Board resolution No. 3553, $3 / 23 / 70)$

Implementation of Schools for the Seventies Plan: 1970-1977

Tax Levies

In order to convert to middle schools, the district needed to secure funds for the remodeling of buildings. The plan would convert seventeen existing schools and build three new ones to serve as middle schools. The district embariked on a series of budget elections to raise the necessary funds.

In October, 1971, the superintendent said "both Portland's educational and building needs... [were] stymied this year with the defeat of four key money measures by the public." Two teacher organizations interpreted the tax 
levy failures differently. The Portland Association of Teachers said "it was not a vote against the schools, but - . a result of voter's disaffection with a heavy reliance on property taxes in funding education" loregonian, 9/29/71, p. 1). However, the presideit of the Portland Federal of Teawhers called for the firing of the superintendent and the majority of the board members. He said the defeat of the levy was "due to the erosion of confidence in the schools and the Board, not the tax structure" (Journal, 9/29/71, p.1).

Although a citizens group formed to help with the next budget election, the school levy failed by a slim margin in May, 1972. The superintendent said, "The people have spoken. The problems remain. As a result of this vote, Portland is no longer competitive with the better school systems in our state" (Oregonian, 5/24/72, p. 1) This series of defeats meant that the district could not pursue its planned development of middle schools.

\section{Early Childhood Centers}

Although the defeat of the tax levies slowed the implementation of middle schools, the conversion of Albina grade schools to Early Childhood Education Centers (ECECs) began. Irvington grade school was the second Model School to be converted to a K-5 Early Childhood Center. Eliot grade school had been the first. 
Between 1972 and 1977, Humboldt, King, and Sabin would be converted to Early Childhood Centers, with the remaining Albina elementary schools, Vernon and Woodlawn, converted to ECECs in the 1977-78 school year. Boise grade school was the only $\mathrm{k}-8$ grade school in the Albina area, mainly due to a strong coalition of parents and neighborhood residents who lobbied the school district to retain it as a Basic Skills Center Willamette Week, $4 / 17 / 78$, p. 1).

All upper grades in the Albina area schools had been removed in the conversion to ECECs, thus all area students from fifth through eighth grade had to transfer out of the neighborhood. The absence of new middle schools in close proximity to Albina produced an increase in administrative transfer students. In 1972-73, when the ECEC conversion began, there were 725 students in the administrative transfer program, 475 of whom were in-district elementary students. In $1977-78$, the admiristrative transfer program totalled 2,888 students, 2,009 of whom were in-district elementary transfer students (PPS, 1978).

\section{Middle Schools}

At the same time, there were eleven middle schools by 1977-78, but only two of them (Columbia-Whitaker and Fernwood) served as assigned middle schools for Albina residents. Various neighborhoods had rejected middle schools 
for their area. The be. 1 had adopted a policy of never placing a middle school in an area where the parents rejected the concept. In the Wilson and Roosevelt High School areas, the citizens had rejected middle school proposals (oregonian, 7/11/78).

Some of the reasons for community opposition to middle schools is cited in an article on Fernwood Middle school.

Opponents of middle schools . . have consistently been charged with opposing middle schools because they offer the district an opportunity to increase racial integration. This is so because middle schools are one step removed from neighborhood schools (typically, students from three elementary schools are bused to one presumably central middle school). Combining students from three schools gives the district the chance to put students from mostly white schools together with students from integrated schools.... Many white parents don't like their children removed from the close-by neighborhood school and bused to a school considerably farther away, even if that school isn't in the black community. (Willamette Week, 7/2/79, p. 7).

There was dissatisfaction on the part of black parents as well, because no middle schools had been created in Albina. Therefore, their $6 \mathrm{th}, 7 \mathrm{th}$, and 8 th grade students were all bused out of their neighborhoods.

\section{Citizen Advisory Committees (ACACs)}

Three Area Citizen Advisory Committees were created as a result of the board's adoption of the "Schools for the 70s" plan. In 1974, the superintendent, speaking to the National Committee for Citizens in Education, reported that citizen involvement and decentralization were operating 
well in Portland. He said that 25,000 citizens were directly involved in everyday operations of the school (Journal, $6 / 25 / 74)$.

The Area Citizen Advisory Committees were a key part of the school district's community involvement process. The Schools for the City, a citizen committee formed in 1972 to assist with that year's budget election, evaluated the ACACs from 1970-75. They concluded that although the advisory committees have "clearly influenced Board decisions and administrative actions. . . two major blocks remain to be overcome." The first major block was that the "whole process is rigidly controlled by the School Board." The second block concerns the advisory committee's uncertainty over its actual role in ecucational decision-making. (Schools for the City, 5/19/76, p. 20) They specifically recommended strengthening of the Advisory Committees:

1. Particular attention be paid . . . to inclusion of citizens in planning policy changes from initial consideration to conclusion of the process;

2. $A C A C^{\prime} s$ need to function in a more independent manner - . also be advocates for the public;

3. Review panel members (who select ACAC's members) be chosen . . . so that their selection is not controlled solely by the school Board.

(Schools for the City, 5/19/76, p. 20).

Another citizen commented in a Letter to the Editor about the need for some changes in the citizen advisory process.

Area advisory committees should be elected. Local advisory committees should either be elected, or all interested parents should be allowed to serve and vote on issues. Further, all advisory committees should be given more quality information and copies of all policy proposals and budget 
recommendations. Committees should be involved in all stages of budget formation, teacher and principal selection criteria and hiring, and review and development of school programs and curricula. (Oregonian, 7/11/78, p. c6).

In summary, the major critici.sm was that the area advisory committees were consulted frequently too late in the decision-making process to provide input and to have an impact.

\section{Federal and State Decisions on Desegregation Policy}

On March 22, 1974, the State Board of Education adopted Policy No. 4171 on "Racial Imbalance in Public Schools." The policy stated:

It is the affirmative duty of each local school district which has a substantial racial minority student enrollment to formulate policies, and to plan, implement, and evaluate educationally sound and feasible programs, to prevent or eliminate racial isolation in its schools, and to achieve and maintain an integrated education program characterized by mutual respect, awareness of cultural diversity, and responsiveness to the needs of all students. Racial isolation exists in a district if the combined enrollment of Black, Native American, MexicanAmerican and Asian-American students in any school of the district is in excess of fifty percent (50\%) of the school's total enrollment. (State Board of Education Policy No. 4171, 1974)

In direct response to the State Board's policy, the Portland School Board reaffirmed their 1964 and 1970 actions on policies and programs to reduce racial isolation of minority students in its schools. It also directed the superintendent to encourage and increase administrative 
transfers "to the fullest extent practicable" and to continue the conversion of selected elementary schools to Early Childhood Centers. They instructed the superintendent to recommend steps to reverse increasing minority enrollment when it is in excess of $25 \%$, and to analyze the situation when any school reaches 10\%. (School Board Minutes, $5 / 22 / 75)$

Although the federal government through the courts and legislation had defined that no school in a system should depart substantially from district-wide racial proportions (Pascal, 1977), the major struggle for state and local boards of education was how to achieve this racial balance. Racial balance and desegregation at this time refer to the "physical mixing of the races without regard to the relative status of the two groups" (Gordon, 1977). There was growing concern with the legal concept of racial isolation. In a review of legal decisions, one education writer noted that "racial balance as a numerical goal will not necessarily improve the quality of education in the public schools . . the problems must be solved by educators, not lawyers, legislators and the courts" (Oregonian, $4 / 3 / 77$, p. 1). Other community studies of desegregation have demonstrated that community involvement was a key ingredient in both a successful desegregation and improved educational program (Crain, 1968; Kirby, 1973). Portland was not under a court-ordered desegregation 
ruling to integrate its schools. The board had initiated its own plan, as a result of the schwab committee and community pressure in 1964. Portiand through the years had stressed the fact that its desegregation plan was voluntary. However, according to a september, 1977 staff report of the U.S. Commission on Civil Rights, the desegregation plan was limited in scope and effect.

Desegregation in Portland . . involves . . 'oneway busing' of minority (mainly black) students from inner-city schools to predominantly white ones . . (p. 6)

Another problem area rests with the continuing feeling among some members of the minority population that the burden of the desegregation process has been borne by minorities. (School Desegregation in Portland, Oregon, p. 14)

However, the Portland Public Schools were found in violation of the "Singleton Rule" in 1975 by the Office of Civil Rights. The "Singleton Rule" resulted from a 1970 Supreme Court decision that ruled school districts should assign staff so that the ratio of Negro and white teachers to other staff in each school is substantially the same as such ratios are to the teachers in the entire school system. The Office of Civil Rights (HEW) found Portland to have a disproportionate concentration of minority teachers in racially isolated schools. The district, in order to avoid the loss of funds, transferred all minority teachers to achieve the ratio recommended in the "Singleton Rule." In 1977, the Office of Civil Righics Lhreatened to 
withhold Title VII, Emergency School Aid Act (ESAA) monies because the Portland school district was aiscriminating against minority students in its suspension policies. The school district had to agree to change their suspension policies in order to remain eligible for the Title VII funds, federal funds for assisting school desegregation. In summary, school desegregation in Portland as of June, 1977 had employed several approaches to accomplish its objectives.

Since 1964, a voluntary transfer program (Administrative Transfer Program) has been in use to bring about desegregation. In 1970, the Portland School District changed attendance boundaries and embarked on a middle school policy, citing desegregation as part of the rationale for middle schools. In 1970, the District also adopted a policy (which eliminated grade levels in these schools) of converting elementary schools in the Black community to Early Childhood Education Centers. This policy has since been classified by the District as part of its desegregation efforts. (Equity for the 80s, 11/78, p. 43)

\section{Analysis of Desegregation Policy--} Portland Style: 1962-1977

In the first stage, problem identification, different groups in the community (NAACP and the committee of 125) raised the issue and defined the problem for the school board. The board appointed a blue-ribbon panel, the Schwab committee, to formulate a course of action. The Schwab committee developed a set of recommendations which the school board adopted as its desegregation plan for the Pcrtland school district. That was the legitimation phase of the policy process. The application stage was the 
Model Schools, a compensatory education program, which was implemented from 1965 to 1970. The other part was the Administrative Transfar program which began in 1965 and was still operational in 1981.

The goals of desegregation were the reduction of the concentration of minority students as well as improved education. Criticism arose from the minority community about the Model Schools program because the racial composition of the predominantly minority schools did not change. The Model Cities Education Committee (1968-69) and the Citizens Committee for Better Schools (1969) had both called for an end to the Model Schools and a cross-busing approach in which both white and black students would be bused. Although there was no formal evaluation of Model Schools, segments of the community did call for major changes in the desegregation programs. (In 1972, the City Club did a formal evaluation of the Model Schools program, finding that it was ineffective. But, by that time, the program had been discontinued.)

The school board did not accept either set of recommendations, but did reformulate its desegregation policy by hiring a new superintendent who presented his "Schools for the 70s" plan. The superintendent and the board were the chief actors in altering the desegregation plan, although citizens were consulted through the series of public hearings. This second desegregation plan focused 
on reorganization of the schools and a continuation of the Administrative Transfer Program.

The Schools for the $70 \mathrm{~s}$ plan was adopted llegitimated) in March, 1970. During the implementation stage of this plan, financial problems arose (defeat of tax levies) which resulted in further modification of the plan, especially with the development of the middle schools. Community opposition to middle schools slowed down the process even further. At the same time, the federal and state governments were redefining "acceptable limits" in desegregation with an increased emphasis of reducing the concentration of minority students under 50 percent in any school.

Due to the inability of the school district to reorganize into $\mathrm{K}-5,6-8,9-12$ desegregated schools, the board moved to reduce racial isolation through an increase in the Administrative Transfer Program and the conversion of Albina schools into Early Childhood Centers. The board and the superintendent $i \cdot n l i e v e d$ that such programs were sound educationally, and would promote progress in reducing the numbers of racially isolated schools.

The school board was guided during this time period (1970-77) by several criteria. One was to avoid a courtordered desegregation plan. Second, it did not want to consider cross-busing, because of the fear it would result in white flight from Portland to suburban schoois. (Interviews, $8 / 27 / 80,7 / 31 / 80,9 / 8 / 80)$ 
Like voluntary programs elsewhere, Portland's "administrative transfer program which involved for the most part minority students, desegregation has not produced change through the city schools."

One expressed fear is that the white community's heretofore generalized acceptance of desegregation may be threatened if a heavier burden is placed on whites in the future implementation of desegregation. (School Desegregation in Portland, Oregon,

$9 / 77$, p. 14)

This historical analysis of desegregation policy has identified the critical participants in the policy process, as well as reported the changes in the desegregation policy process. In addition to knowing who the participants are and the issues, it is necessary to consider the impact of the desegregation policy cn. Portland's citizens and their view of the policy in 1977. The next chapter anaiyzes community dissatisfaction with the desegregation policy in the summer of 1977 . 
CHAPTER IV

\author{
COMMUNITY DISSATISFACTION WITH \\ THE DESEGREGATION POLICY
}

If the previous chapter demonstrated the efficacy of the early policy model, initiation-implementation-evaluation, we can now see the concept of dissatisfaction coming into play as the next important variable, the community's intervention, is examined. In this chapter an analysis of the sources of community dissatisfaction will be made from the perspectives of the community, board, and school district. Dissatisfaction with the school district's desegregation plan had been present since the first plan was initiated in 1965. In June, 1977, a policy change was proposed to the school board, because Jefferson High School had passed the 50 percent minority enrollment limit during the 1976-77 school year. According to the state board's guidelines, Jefferson was a racially isolated school. In an effort to lower minority enrollment, it was proposed by the board that children from Boise and King grade schools not be allowed to attend Jefferson High School, but would be assigned to Lincoln and Wilson High Schools.

Boys and girls from two mainly black neighborhoods would be forbidden to enroll at Jefferson High school under a draft policy submitted to the 
Portland school board. Such a student would have to attend another high school which had about average enrollment of black students. (Oregon Journal, 6/8/77, p. 3)

The goal of the Boise-King (6/77) plan was to further desegregation efforts in Portland's schools and to meet the State Board of Education requirement that no school's enr.ilment exceed a maximum of 50 percent minority students. Also stated was a goal to prevent and eliminate racial isolation of minority children (Attendance Area and Transfer Policy Draft, 6/6/77, Section B, Paragraph 5).

The proposed policy change was announced at the end of the school year. Between June 6, 1977, when it was introduced to the board, and July 25, 1977, when the board finally acted on the policy change, community dissatisfaction over school desegregation surfaced through several local groups.

\section{Community Reaction}

Several community groups were aware of citizens' complaints about the current desegregation efforts. The education committee of Metropolitan Human Relations Committee (MHRC) had discussed a review of the district's desegregation policies and practices, as it had not been evaluated since the Schwab committee study in 1963-64 (Interview, 6/10/80, 6/17/80b). The MHRC education committee met with the superintendent and several board 
members to discuss the Boise-King redistricting proposal in July, 1977.

They recommended that the school board make no decision on the controversial desegregation amendment until at least $2 / 78$. . In the interim the district (should) involve the community in the sharing of information and planning. (Portland Observer, $7 / 21 / 77, \mathrm{p} .1)$

Schools for the City, a citizens' education advocacy group, had raised the question of how desegregation was doing in Portland the year before. The League of Women Voters also had informed themselves about the issues surrounding desegregation. (Interviews, $6 / 18 / 80 \mathrm{~b}, 6 / 19 / 80 \mathrm{~b}$ )

Through the interest of MHRC and the concerns of one board member over the progress of desegregation, a small group of parents and Northeast community residents began meeting Saturday mornings at King school to discuss a number of problems with the desegregation plan: curriculum, discipline, transportation, recruitment of minority teachers, and Jefferson High School. Several weeks after this group began meeting, the concerned board member brought the "redistricting" proposal to a meeting. The community group was very interested in responding, but due to the timing, were concerned as to how they could inform parents at the end of the school year. They decided to formally organize and called their group the Committee for Quality Education for All Children. A long-time Northeast community resident, active in Model Cities, became chairperson. In 
order to spread the word to other affected parents, the Committee contacted Jefferson High School groups; requested to testify at the next board meeting; and sent out a mailing to civil rights and human relations groups, and the media, informing them of the Committee's opposition to the proposed policy change.

The "Friends of Jefferson" had been active for several years. They represented parents, students, and community residents committed to the improvement of Jefferson High School. They joined with Boise parents and Boise Neighborhood Association's Education committee to oppose this proposed change. As part of the coalition with the Committee for Quality Education, they discovered that white flight was responsible for the racial imbalance at Jefferson. "The outflow of majority students from the Jefferson feeder schools to other high schools is the primary reason for the increasing percentage of minority students" (Observer, $7 / 21 / 77$, p. 1 ).

When the school board member presented the redistricting proposal on June 6,1977 , the district had not anticipated any opposition to what they considered more of a "boundary change than a policy change which requires no community input" (Observer, 7/21/77, p. 1). The first sign of community opposition came from the media coverage of a press conference called by the Committee for Quality Education for All Children. 
A proposal which, in effect, would bar some black students from attending Jefferson High School - . is under fire from a group of black leaders and parents. The group, Committee for quality Education for All Children contends that the proposal . . unfairly puts the burden for racial desegregation of Jefferson on black students. (Oregonian, 6/21/77, p. 1)

Some board members and central school administrators met with selected black leaders before the proposal's second hearing at the July 13, 1977 board meeting. These black leaders, after hearing an explanation of the new attendance proposal, advised "the school personnel that they meet with the Committee for Quality Education for All Children and affected parents before making any decision on this proposal." The school district did not get support for the proposal from the black leaders who attended this meeting. (Observer, 7/7/77, p. 1; Oregonian, 7/25/77)

On the night of July 13, 1977, the board delayed the public testimony on the policy change until the end of their regular agenda. The result was an angry reaction by "the sixty persons who waited more than three hours to be heard" (Oregonian, 7/15/77, p. c1). Fifteen persons spoke with four groups presenting written testimony as well. The speakers asked the board to reject the proposed policy change and to involve the "entire community in planning an integration program that is acceptable to the community" (Letter frrm Committee for Quality Education to the board, 7/13/77). Rather than decide the issue that 
evening, the board called a special meeting for July 25, 1977 which would be devoted entirely to the desegregation policy change.

The media was very involved in covering this issue. The Oregon Journal $(7 / 20 / 77)$, in an editorial entitled "It's Time To Take a New Look," pointed out that part of the biack community's opposition to the new plan was due to the way the schcol board had handled the proposal. "The plan was announced without consulting beforehand the community immediately affected or the comrnunity at large, both of which have much at stake in the vitality of city schools."

The oregonian $(7 / 23 / 77)$ reported that "a coalition of community groups has asked that the board appoirt a citizen committee to study alternatives to the proposed change in the desegregation plan" (p. A8). The Oregonian $(7 / 24 / 77)$ also discussed the reason for the community's opposition:

They are objecting to the method proposed to achieve the goal--mandatory busing of a predominantly black segment of the Jefferson high school attendance area to Westside high schools, Lincoln and wilson. (Oregonian, 7/24/77, Sunday Forum, p. D1)

The July 25, 1977 meeting was attended by 200 people, so many that the overflow from the board room moved to standing room only in the halis (Observer, $7 / 28 / 77$, p. 1). The superintendent opened the meeting by reading a prepared statement. He said: 
the district has the responsibility to make policy decisions that do the right thing. The right thing for Portland is desegregation and this is the direction the Board of Education has followed. We have made a significant number of attendance area shifts. Few or none of them have been without opposition. Typically, they were for the reason of sustaining efforts to follow the desegregation plan of the district. This plan is to carry out a constructive desegregation program. Obviously, the effort has been to accomplish this without disruption of a court order. (Portland Public School memo to Board of Education, 7/25/77, p. 2)

The superintendent recommended that the board request that the NAACP, Urban League, and Metropolitan Human Relations Commission address the Jefferson imbalance issue. He also recommended the deferral of a decision to $12 / 15 / 77$ because "I think it impractical to proceed at this time... without sone support from groups who are traditionally committed to the goals that are involved here" (Portland Public School memo to Board of Education, 7/25/77, p. 5). He also commented that

I am very troubled when influential groups and individuais take exception to proposals based on the amount of criticism voiced rather than on the merits of the issue. This comment was interpreted by many as a slap in the face at dissenting citizens. (Oregonian, $7 / 26 / 77$, p. A1)

The audience response was immediate. The chair of the Committee for Quality Education said "we resent the implication that we are rabble rousers" (Board minutes, 7/25/77). A representative from the Boise neighborhood said the superintendent had "insulted the community who gave up their time voluntarily to be involved," and that the "black 
community will not accept certain groups to make decisions. We want a voice in the decision." (Board minutes, 7/25/77) The NAACP representative objected to the naming of the three organizations.

You should have asked the neighborhood who should be on the committee. Try to get some feedback from the community as to whether it wants those three organizations. (Journal, 7/26/77, p. 1)

The other two organizations, MHRC and Urban League, both had representatives at the meeting. MHRC agreed to accept the challenge, but did not agree with the Board's decision to "restrict input to Jefferson when the program needs to be studied in depth" (Board minutes, 7/25/77). The Urban League speaker expressed his concerns about the process.

You dian't wait to hear our recommendations. The NAACP, Urban League, the Metropolitan Human Relations Commission represent the black community. The process is merely dumping the issue back on blacks, saying you come up with something better. Why not create a commission of all individuals and let the chips fall where they may? (Board minutes, $7 / 25 / 77$ )

The board voted unanimously to ask the three organizations to develop their own proposal for Jefferson by December 15, 1977. Several board members and the superintendent also expressed the hope that other groups would be involved in addition to the three named organizations. However, there was no clear statement from the board as to whether these three groups should examine the entire desegregation program. (Board minutes, 7/25/77)

The board decided to create an independent group, 
rather than appoint a blue-ribbon panel like the Schwab committee, for several reasons. As citizen distrust of government increased, blue-ribbon panels had become suspect for too close a relationship with the administration. (Interviews, $8 / 20 / 80,9 / 8 / 80,8 / 12 / 80$ ) The board, faced with community opposition to its proposal, needed to get a genuine, independent look at desegregation policy. It was felt that would not happen with a board-created or board-controlled group.

Individual board members had various reasons for their support of an independent study group. One believed that citizen input was necessary even on controversial issues (Interview, 8/12/80). Another thought that if reasonable people, committed to integration, would examine the desegregation program, they would support the current program (Interview, 9/8/80). A third view, also substantiated in the media, was that the board's decision was an indignant reaction to community outcry over the handling of the Boise-King plan (Interview, 8/26/80).

Regardless of the intent of the board and the superintendent, the three groups were committed to involve the whole community in addressing the problems with the desegregation programs (Interview, 6/17/80b). 
Factors Contributing to Community Dissatisfaction

Community Perspective

According to one analysis of political change, people need to act at the right time on the right issue with the right leaders and the right people

in the right place. (Barber, 1969, p. 166)

Community people who testified before the school board in July, 1977, all agreed that the proposed policy change was the culmination of a series of decisions on desegregation that primariiy affected the black community $16 / 18 / 80$ a, $6 / 18 / 80 \mathrm{~b})$. It was the right issue, but the timing of the proposed policy change was awkward. It came at the end of the school year, when many people were making summer plans. The timing may have presented initial difficulties, but the right people and leaders were ready to address the issue (Interviews, $6 / 11 / 80,6 / 19 / 80 \mathrm{~b}$ ). "The issue was volatile, tangible and visible" (Interview, 6/17/80b).

Jefferson was the symbolic black high school which a number of black and white parents were committed to preserving, as was the school district which had invested thousands of dollars in order to improve educational opportunities and to attract more white students. A policy change that affected only Jefferson High School by transferring only black students out of Jefferson had a strong impact in the black community. Some felt this was an 
effort to get rid of Jefferson, the "bad, black school" (Interview, 6/20/80). Others feared that the policy change would result in the elimination of all grade schools in Albina, because the proposed change would mainly affect Boise School, the only $\mathrm{K}-8$ school remaining in Albina (Interview, $7 / 24 / 80$ ).

Others saw the proposed policy change as an overt sign that the district was in serious trouble. The board, for the first time, proposed a desegregation policy change based solely on race (Interview, 9/15/80). The black community saw the board reacting to a crisis, and that their solution would once again affect black students (Interview, $6 / 17 / 80 a)$. More importantly, the nature of the policy change indicated that the board was not following their announced desegregation plan, but had reacted to the crisis with emergency measures (Interview, 4/18/80).

The two board meetings in July, 1977 also provided an outlet for parents' complaints about desegregation (Interviews, $6 / 10 / 80,9 / 15 / 80,9 / 19 / 80$ ). The community's presence at the board meetings made the issue visible to the greater Portland community because of extensive newspaper and television coverage. These parents learned that other people were concerned about the same issues.

The leaders of the groups opposing the "redistricting" plan felt that this was a cricical and timely issue. The black community's attitude on the busing issue had changed 
(Interview, $7 / 25 / 80$ ) and the school district was unaware of these changes (Interviews, $6 / 2 / 80,7 / 25 / 80 \mathrm{~b}, 9 / 8 / 80$, $9 / 21 / 80)$. The changes were reflected by the questions being asked about the issue: is there data that shows that desegregation provides quality education for black children?" (Committee for Quality Education, Board minutes, $7 / 25 / 77)$

The Oregonian described the change in the black community as

After 14 years of school desegregation, the focus of black concern has turned from fighting for the right to attend white majority schools to examining what happens to black students after they get there. (Oregonian, 11/16/78, p. B1)

There was a new group of younger black leaders, several of whom had been involved in Model Cities and the war on Poverty community action programs in the $1960 \mathrm{~s}$.

Another factor was community awareness. Through the efforts of groups like the Committee for Quality Education, Black Concerned Parents, and Jefferson High School parent groups, the black commurity was more aware of the issues. There was also growing white liberal dissatisfaction with the board's direction on desegregation. Some city-wide education groups had decided to examine those areas. (Interview, 6/19/80b)

Citizen involvement has been present in other government arenas in Portland. Citizens were very active in the campaign and election of a major in 1974 who encouraged 
citizen involvement in budget planning, economic development, and crime prevention. Throigh Model Cities and then the neighborhood association movement, citizens were involved in making decisions about housing, freeways, and neighborhood revitalization (Interviews, $4 / 18 / 80,8 / 6 / 80 \mathrm{~b}$ ). During the 1970 s in Portland, a cadre of experienced community organizers developed who believed that citizens could make a difference in solving community illatters.

\section{Board Perspective}

Board members offered several explanations for the community's response to the proposed policy change on desegregation. Although citizens had testified against the district's desegregation plan during the 1970s hearings, the current board was surprised by the degree of opposition of the black community to the proposed "redistricting" plan. One board member attributed some of the community reaction to the presence of someone on the board who was willing to raise questions, which in turn encouraged dissatisfied citizens to do the same (Interview, 8/26/80).

Another board member thought the desegregation language ill-advised. Fifty-one percent black made a school "racially isolated," but not fifty percent white. Also, Jefferson, because of the district's financial investment in making it a magnet school, was a success and black children wanted to attend it (Interview, 8/20/80). 
A long-time board member identified several historical and political factors which contributed to the black community's dissatisfaction with the prevailing desegregation policy. (1) The City of Portland had a commitment to neighborhood revitalization. There was tension between the need to plan city-wide desegregation and the retention of the neighborhood primary school, which is vital to neighborhoodness. (2) The experience of Model Cities, Office of Economic Opportunity - Community Action Programs (OEO-CAPS) and affirmative action had demonstrated the positive results that black group action could bring. (3) The nature of black leadership had been changing in Portland with an influx of younger blacks with successful experiences with direct action programs. The board was not in touch with this emerging black leadership. (4) The district had been making slow progress on desegregation, due to the defeat of the tax levies and time-consuming reorganizational efforts. Both blacks and whites reacted negatively to these delays. (Interview, 9/8/80)

\section{School District Perspective}

School district staff also recognized that leadership in the black community had shifted and that the district failed to involve the newer leaders in desegregation planning. Also, a second generation of concerns was being expressed on the part of community members who had been participating in desegregation efforts. Questions as to 
what difference does it make if a black child attends a desegregated school had become a primary concern. (Interview, 6/2/80 and Committee for Quality Education, Letter to Board, 7/25/77)

The national picture had been changing as well as the local scene. Politically, the country had moved through the conservative period of the Nixon presidency, in which there was increased support for anti-busing position. Nationally, civil rights leadership was divided, as more blacks were supportive of community control of schools. Locally, the traditional civil rights organizations were no longer "unequivocally" supportive of desegregation, as they had been in the 1960s. (Interview, 8/28/80)

The board was accustomed to making decisions in a consensus framework. Previously, it shared its plans with representatives of the black community and had public hearings at its board meetings. It assumed that the community could reach consensus on the issues, but there was no consensus on this issue. The desegregation issue had changed in the minds of a number of black participants. The black community was dissatisfied and through organizinc; various segments of the community, spoke out strongly against the policy change. The coalition facing the board was the product of conflict, not consensus, decision-making. The school system responded to this conflict by asking some traditional civil rights organizations to 
recommend a solution to the problem. The board, acting from a consensus perspective, still believed reasonable people would see it their way, after some study of the situation.

In summary, segments of the community had expressed a strong interest in studying the desegregation plan in its entirety. The board's response was to ask three organizations to make recommendations on the Jefferson situation by December 15, 1977. The next chapter will discuss the formation of the Coalition and its decision to expand its mission to study the entire desegregation plan. The second section will analyze the policy intervention, using Rothman's (1968) models of community organization practice. 


\section{CHAPTER V}

\section{ANALYSIS OF THE POLICY INTERVENTION}

Before this chapter provides an overview of the critical events in the life of the coalition $(8 / 77$ to $9 / 79)$ and an analysis of the policy intervention, the environmental setting of the policy intervention, Portland School District \#1, will be examined.

In 1977, Portland was a city of approximately 380,000 people with a total metropolitan population of over 1,000,000. School District \#1 served an area covering most of the city of Portland, as well as some unincorporated areas contiguous to the City. The district was organized into three Administrative Areas, which operated with relative autonomy (Figure 4) ("Portland Public Schools: 1950 to 1977," Portland Bureau of Planning, April, 1978, p. 1).

Demographic changes had affected Portland Public Schools during the previous decade. Since 1969, Portland school enrollment has declined to 57,000--a drop of 27 percent. ("Portland Public Schools: 1950 to $1977, "$ p. 1) Other characteristics of the school district are: over half of the schools in use were built before 1950; nine schools were closed since 1970; and only two out of ten of the special levies since 1970 have been approved. 


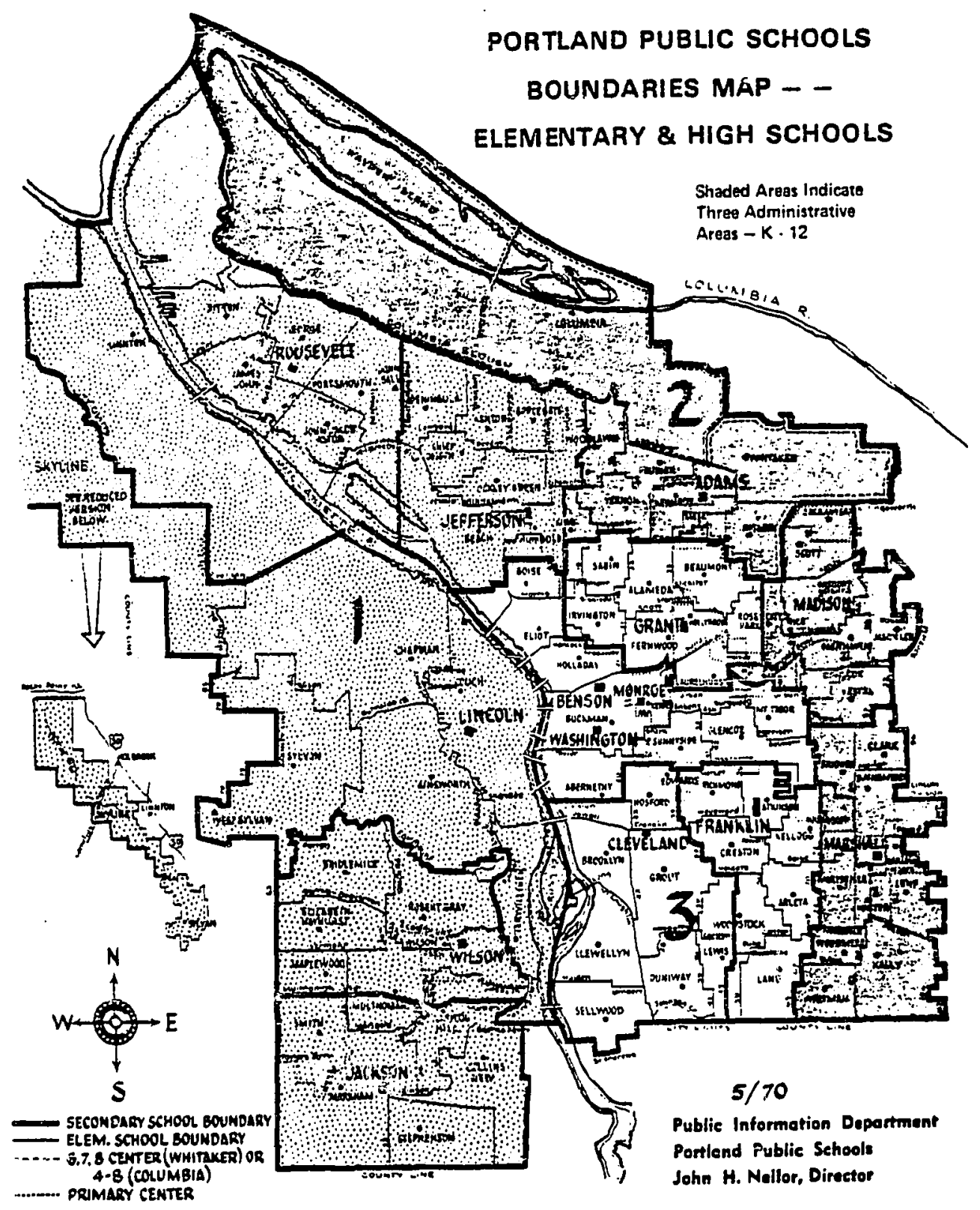

Figure 4. Portland public schools boundaries map-elementary and high schools. 
A recent study of Portland's schools indicated a growing financial problem.

The general population remains relatively constant at approximately 380,000 , but is now composed of a smaller number of school-aged children and a greater number of both elderly people and young adults without children. (p. 3)

With the general population remaining constant, the average tax burden since 1970 has increased little more than the rate of inflation. However, the cost of educating each student has soared, increasing at a rate of $14 \%$ each year, roughly twice the rate of inflation during the same period.

This rate of increase is partly attributable to increased services required by State and Federal legislation, smaller class sizes, and improvements of t.eacher and other employee working conditions and benefits. (p. 9) ("Portland's Public Schools: 1950-1977")

The biggest factor influencing change in the schoolaged population was the continued preference among homeowners for suburban locations.

The City is losing families with children to its suburbs through net out-migration. Also, families with children who move to the SMSA [Standard Metropolitan Statistical Aree] tend to settle in suburban areas. ("Residential Mobility Study for Portland, Oregon," Office of Planning and Development, April 17, 1978, p. 10)

This decline is expected to continue as Portland Public Schools now graduates more students than it enrolls in kindergarten.

The other important factor for Portland schools desegregation plan was that the enrollment decline has been mainly white families. In 1970, black students were 9.28 (or 7,008 ) of the district's total enrollment (1979 Enrollment Report, Portland Public Schools, p. 24). In 
1979, blacks represented 14.78 (or 7,910 ) of the total enrollment. The number of black students increased only slightly, but the percentage rose due to the loss of white students from the district. Total minority enrollment in 1979-80 was 23.2\%. ("Superintendent's Annual Report to Board of Education on Racial Balance," Portland Public Schools, 1980, p. 4) Prior to 1970 , the school district only kept figures on black enrollment as the minority enrollment figure.

The black population was concentrated in Northeast Portland. In 1979-80, seven Northeast grade schools-Boise, Eliot, Humboldt, King, Sabin, Vernon, and Woodlawn-exceeded 50 percent minority enrollment and according to the state guidelines, were considered racially isolated schools ("Superintendent's Annual Report to Board of Education on Racial Balance, 1980, p. 21).

Since 1970, the district and board had used the combined approaches of Early Childhood Education Centers, Middle Schools, a magnet high school program at Jefferson, and the Administrative Transfer program to promote desegregation in the schools. Although it had not been successful in resolving the problem of racially isolated schools, a result of housing aiscrimination patterns, the district had worked to reduce the number of black students in racially isolated schools.

The district believed it had a successful 
desegregation program. It stressed the educational dividends of the various desegregation programs to both the black and white commurity. In 1976-77, 700 white children voluntarily were bused to Early Childhood Centers (Oregonian, $11 / 12 / 78$, p. B1). There were 1,700 volunteer chilaren in the Administrative Transfer program (90\% of whom were black). An additional 800 students were "involuntary transfers" as there was no upper grade center in their neighborhood. Some of them had been assigned to midale schools, but there was dispute over the actual number who had not been reassigned. The school district claimed that only 350 realiy were "involuntary transfer," whereas the Coalition maintained that the figure was closer to 700 students (Oregonian, 11/24/78, P. B1).

Another factor in the desegregation accomplishments, was that desegregation had not involved any major litigation, nor had there been any serious opposition from any segments of the white community. The real constraints hud been financial. With the defeat of the tax levies in 1971 and the resulting delays in middle school conversion, the district made the Early Childhood Centers and the Administrative Transfer programs the major components of its desegregation program. As federal and state requirements for school desegregation progress increased, the district and board acted to diminish the racial isolation of certain schools. The Boise-King redistricting plan was one such 
response. (Interviews, $8 / 27 / 80,9 / 8 / 80,6 / 2 / 80$ and "Superintendent's Annual Report to the Board of Education on Racial Balance," 1980, pp. 5-6)

The emphasis of the district's desegregation plan had been that of racial balance. A district spokesman said, "the purpose of busing blacks to a large number of schools is to have better racial balance in all our schools" (Oregonian, $11 / 15 / 78$, p. B1). The district wanted to reduce the number of all-white schools. Although the district emphasized the educational benefits of Early Childhood Centers, Middle Schools, and the Administrative Transfer Program, there was no evaluation of these programs or of the students who participated in them.

To date, the school district has no conclusive testing data on black achievement inside predominantly white classrooms. . . . the district only recently set up a testing program able to measure the effect of school desegregation on black achievement. However, school officials have determined that the pre: ance of black children in white classrooms has not lowered the average white achievement levels--a conclusion which is consistent with national findings. (Oregonian, 11/16/78, p. B1)

Several district staff explained that achievement data was not collected hecause the primary goal of school desegregation was social, not educational. In fact, assessment might detract from the goals of the desegregation plan, whose emphasis was on racial balance. (Interviews, 8/27/80, $9 / 3 / 80,7 / 23 / 80)$

Academic achievement was the very issue that the black community had begun to view differently. After 
fourteen years of school desegregation, many black parents were concerned with the quality of experience black children were receiving. Other issues were: discipline practices, teacher attitudes, and transportation. Specific complaints of the black community during the summer, 1977 board meetings reflected their concerns. For some, it was the treatment that black children met at the "receiver" schools where they were bused. Generally, it was felt that the administration, teachers, and children were not prepared to teach or relate to black crilidien.

A growing concern was the number of minority Administrative Transfer students who were suspended or expelled at these receiving schools. Minority student suspensions were three times the percentage of white students in 197778 (Equity for the 80s, 1978, p. 95). Problems with transportation included stories of children who missed the bus and missed school for the day, and of children waiting in the rain until school opened. Because of the distances involved, parents couldn't participate in school support activities and children couldn't stay for after-school activities. (Oregonian, 11/16/78, p. B1; Interviews, $6 / 11 / 80 a, 6 / 12 / 80,7 / 16 / 80 a, 7 / 24 / 80)$

Criticism of the desegregation plan was growing because of the black community's own experiences. A black parent in a letter to the editor expressed one perspective 
on the problem.

I am not against a positive plan that is fair and just to all students. Black, white, and others. I am against forcing black children to be bussed and making all schools in the model neighborhood [Albina] early childhood centers. I felt at the recent School Board meeting that the superintendent insinuated that $I$, as well as others have disagreed with him, am against desegregation. (Portland Observer, $8 / 18 / 77$, p. 2)

Segments of the black community were dissatisfied with the effects of the desegregation plan on their children.

Black leaders, buttressed by the city's white liberal establishment, have charged that creation of the centers has unfairly forced a predominantly black group of students to be bused out of their neighborhood schools, while transfer into the centers have remained voluntary for white students. (Oregonian, 11/24/78, p. B1)

Many blacks began to question the equity of one-way busing to achieve desegregation.

The conflict over the redistricting plan in the summer of 1977 showed the growing gap between the school system and community over desegregation. The school system felt that without the pressure from major community groups, they had gone as far as they could in implementing school desegregation. The board and district believed they had demonstrated strong and progressive leadership in implementing a board-initiated plan. They were proud of the fact that they had avoided a court suit or strong opposition from white conservative community forces. Their attitude can be summed up "we've done as much as can be done in a community like Portland." Thus, they were genuinely surprised 
when the black community reacted so strongly to the June, 1977 redistricting proposal.

The problem surfaced because the black community was asking different questions and responding to different constituencies than the school system. In addition to the goal of equal educational opportunity, they wanted to see evidence of educational quality and equity in desegregation planning. The challenge the board and superintendent gave the community was, in essence, to see if the community could construct is better plan within the framework of state and federal limitations.

The school district and these issues were the setting for the policy intervention by the community coalition. Next, this chapter presents a description of the activities for school integration during the life of the coalition.

\section{Chronology of Coalition Activities*}

Phase I: $8 / 77-1 / 78$

On August 23, 1977, an interim committee, composed of representatives from the Urban League, NAACP, and Metropolitan Human Relations Commission voted "to form a broadbased coalition that would make recommendations to the School Board for implementation in the desegregation program" (Coalition minutes, 8/23/77). Open letters of

*Appendix D, Chronology of Coalition, 9/77-9/79 
invitation were sent to organizations and individuals inviting their participation in the study. At the first meoting $(9 / 1 / 77)$ the coalition became the community coalition for School Integration. It established an organizational structure of a Task Coordinating Committee with several subcommittees for Research, Resources, and Community Involvement.

Between September, 1977 and January, 1978 the Coalition initiated and pursued the following tasks: (1) defining its relation with the board and district, (2) obtaining fundis for staff, (3) conducting research on the Jefferson situation, and (4) getting the community involved in the study and the coalition.

The Coalition clearly wanted to be independent of the school system. At the same time, it needed access to school data and financial assistance. The Coalition was able to obtain funds from the city and county for staff salaries. The school district agreed to provide space, secretarial and telephone services, and a set amount for reproduction costs of the study. It also agreed to make data available to the coalition. A research coordinator was hired in late November and an office was opened in a local school annex. In addition, the coalition asked for technical assistance from various other agencies: HEW, Northwest Regional Educational Laboratory, and the General Assistance Center for Desegregation. The resources of these 
agencies were limited to providing technical assistance to local school districts. As an independent organization, the Coalition could not receive direct assistance. Instead, the Compensatory Education staff at the Oregon State Department of Education served as the major technical resource for the coalition.

Invitations for membership in the coalition were repeated during this time, incluaing a news-release in all papers on $9 / 23 / 77$ and $11 / 23 / 77$. Members selected their own committee assignments. The research committee began to research and prepare its response to the schooi board on the Boise-King plan. The Coalition as a whole agreed to meet twice a month.

The Community Involvement Committee recommended that a series of community forums be held to begin a dialogue between blacks and whites and to provide a means for people to discuss integration issues. Three forums were held in November and December, 1977 at Jefferson, Wilson, and Lincoln High Schools.

The Coalition presented its recommendations to the school board in writing on December 15, 1977. The board, in its January 9, 1978 meeting, voted to "accept the Coalition report and to drop further consideration of the BoiseKing Redistricting Plan" (Board resolution X-4189). The key factor was the Coalition's research finding, based on an analysis of school data, that Jefferson was no longer 
"racially isolated." The second finding was that if all of the white students who should be attending Jefferson were doing so now, the minority enrollment would be only about 27 percent (Coalition statement to board, 12/15/77).

\section{Phase II: $1 / 78-1 / 79$}

The Coalition stated to the Board that its Boise-King recommendations were a first step in its overall study of desegregation in the Portland Public Schools. The board in resolution $\mathrm{x}-4189(1 / 9 / 78)$ responded by voting to "strongly endorse the continuing efforts of the coalition." The work of evaluating the entire desegregation program began. The research committee, with the two research staff, examined national desegregation options as well as analyzing the effects of Portland's current programs. Twelve more community forums were held in the winter of 1978. The community input from the forums became pirt of the evaluation of the desegregation program.

In the spring of 1978 the Coalition extended its deadline until November, 1978, in order to include the results of a survey to be conducted of students, parents. and staff participating in the Administrative Transfer program. The summer of 1978 was spent finalizing research options and analyzing the survey results.

The resources committee continued to work on securing necessary funds. A prominent. business leader agreed to 
solicit funds from the business community. Approximately $\$ 4,000$ was raised from ten major businesses in the Portland area (Coalition memo, 6/13/78). Both the city and county extended their share of Coalition salaries, as did the school district on its in-kind contributions. In addition, the school district and State Department of Education paid a private research firm to conduct the survey. Many of the Coalition members also made contributions to continue the study.

Is the fall of 1978 , the Coalition took its desegregation options out to the community, as well as to meetings with its member organizations, for a second series of forums. The coalition in its three November meetings voted on individual recommendations for its final report. This report was presented to the board in two meetings on November 27 and December 4, 1978. The next three board meetings $(12 / 11,12 / 18$, and $1 / 8 / 79)$ provided time for public testimoney on the Coalition's report as well as the superintendent's response. The board voted on January 22, 1979 to accept nine of the Coalition's recommendations, but it rejected the major recommendation on school pairing. (Board resolutions $x-6118-6127,1 / 8 / 79$ and $1 / 22 / 79$ ).

Phase III: $1 / 79-9 / 79$

By January, 1979, the Coalition had lost its staff and office space due to the end of its outside funding. 
When the coalition met after the board's action, it was again a volunteer organization without staff, space or budget. The reaction of the coalition's membership to the board's decisions on its report ranged from angry frustration to cautious optimism. The Coalition did attempt to reorganize and establish new objectives.

This phase was charasterized by a variety of rapid changes in the local school district. The coalition was not able to continue its active role in desegregation advocacy. An analysis of the events and the changing role of the Coalition will be explored in the next chapter, Impact of the Policy Intervention. A list of some of the events that occurred during this time period follows:

1. Legal complaint filed with Office of Civil Rights, HEW ;

2. Two new school board members elected;

3. Coalition team visited Seattle desegregation program;

4. Coalition began and ended meetings with district about resolutions;

5. Board member died and Coalition co-chair appointed;

6. Black United Front emerged;

7. Long-time school board member and initiator of Jefferson reorganization plan resigned;

8. Boycott of schools by Black United Front proposed; and 
9. Board approved short- and long-term resolutions. Between January, 1979 and September, 1979 four new board members were added to the school board, changing its orientation on various school-community issues. All four were supportive of the Coalition. In July, 1979, a black advocacy group, the Black United Front, emerged and called for a boycott of the schools unless the board acted to alter desegregation policy in Portland (Portland Observer, $7 / 12 / 79)$. On September 4,1979 , the school board voted to change the direction and nature of Portland's desegregation policy.

This summary of the activities of the coalition provides the background for the analysis of the policy intervention. Another important factor influencing the type of policy intervention was the membership of the coalition. This next section describes the background of the members and their orientation towards desegregation in Portland.

\section{Description of coalition Membership}

The Coalition had individual and organizational memberships. Each organization was permitted one representative. In addition, other organizational members could join the Coalition as individual members. This analysis is a composite of several interviews with Coalition members and staff $(6 / 10 / 80,6 / 20 / 80,6 / 16 / 80,6 / 17 / 80,6 / 18 / 80 a, 7 / 14 / 80$, $7 / 25 / 80 d)$ plus material from the Coalition files, such as 
membership lists, as of $10 / 11 / 77$, and Coalition minutes. The Coalition was a diverse organization representing different racial groups, residential locations, occupations, and previous organizational experiences. Coalition membership was approximately sixty percent white and forty percent black. Of the twenty-six organizations that joined the Coalition, one-half of the organizational representatives lived in Northeast Portland, eight iived in Southwest Portland, and three lived in Southeast Portland. Of the individual members (seventy-two), twenty-eight lived in Northeast Portland, twenty-six lived in North Portland, three lived in Southeast, and eleven lived in southwest. Four members gave no address. The Task Coordinating Committee was composed of nine blacks and five whites. Geographically, there were seven from Northeast, four from North, and three from Southwest.

Most of the coalition members were adults. Some high school students did participate in the community forums, the survey, and gave testimony on the final report at the board meetings, but for the most part, the Coalition was composed of adult advocates for the interests of children.

Interviews were conducted with twenty-nine coaition members and two staff members. Sixteen whites and thirteen blacks were interviewed. An occupational breakdown of those interviewed shows the highest number, eleven, held government positions. The remaining categories of employment 
were: five, community activities; three, parents; two, teachers; two, private sector; two, social services; and one each in law, higher education, ministry, and research. Geographically, they were representative of the entire Coalition membership: seventeen lived in Northeast, four in North, seven in Southwest, and one in Southeast. All but one of the Task Coordinating Committee members were interviewed.

Fourteen of the twenty-nine were involved in the community's opposition to the Boise-King redistricting plan and initiated the formation of the coalition. Nine members were appointed by their organizations to work with the Coalition. Five of the twenty-nine interviewed were not consistently involved throughout the eighteen months of research.

The coalition was an interracial coalition composed of individuals and organizational representatives (see Appendix E). Within the Coalition there were subgroups who tended to vote the same way or share the same point of view regarding integration. Membership in these subgroups overlapped, but the purpose of identifying these subgroups is to illustrate the range of perspectives within the Coalition. (Interviews, $6 / 10 / 80,6 / 20 / 80,6 / 16 / 80,6 / 17 / 80 \mathrm{~b}$, $6 / 18 / 80 a, 7 / 14 / 80,7 / 25 / 80 d)$

Among whites there were three major subgroups: "westside liberals," inner Northeast "new integrationists," and 
North/Northeast "old-timers." The "West-side liberals" were people involved in organizations like the City Club, Schools for the City, and a variety of Iiberal causes in the city. Other Coalition members believed the whites had access to the city power structure. They were resented for this power connection, but at the same time coalition members expected them to use it on behalf of the coalition. (Interviews, 7/24/80, 7/16/80a, 6/18/80a,6/12/80) These "liberals" were very active in ail the commicices.

Their counterpart on the east side of Portland were the "new integrationists." These were mainly professionals who had moved into the successfully integrated neighborhood, Irvington, and who were strongly committed to integration, as were the west-side liberals. They were perceived by other Coalition members to have worked hard for their neighborhood grade school, but not for the rest of the Northeast schools. Several of the families were bi-racial or had adopted a minority child. They were more affluent and thoughc to have more power access than the other Northeast participants.

The North-Northeast "old-timers" Iived in neighborhoods that were part of the old Model Cities area, but had not yet been touched by the "revitalization" boom of Irvington. They had integrated in a different way, i.e., mainly they were whites who had not left as blacks moved into their neighborhoods. Many of these whites became committed 
to achieve the best education for blacks and whites in their local schools. Increasingly, they saw the issue as that of "class, not race." The parents' groups from Jefferson High School were an example of this group. They, like the blacks, felt the school system did not listen to them. This group tended to identify with the black perspective. Generally, they felt and were perceived to have less access to power than the other white subgroups involved in the Coaljtion.

A bi-racial group, the "human relations professionals," was composed of blacks and whites who had a long-term commitment to the improvement of race relations in the city. These blacks and whites through their jobs had access to resources and the power structure which they used to further the Coalition's work. Their work experiences made them more willing to push the issue further politically than the "west-side liberals." They played a strong facilitating role in the Coalition.

There were three major subgroups of blacks, the second generation "new leaders," the first geveration "historical leaders," and black "activists." Among the "new leaders" there was a range of backgrounds. The young "comers" were members of traditional civil rights organizations, but they were willing to use different methods to achieve desegregation than the historical leaders. They were skilled professionals with organizational experience 
in social change situations and provided much of the leadership in the Coalition. Some were black professionals who participated because of their jobs. A third group, the "activist" blacks, were outspoken and willing to push the Coalition as far as they could. They servea as lead-point persons and were frequently on the cutting edge of an issue. Their insights generated a lot of conflict witrin the coalition, but also served to communicate the anger and frustration of years of struggle over this issue with the school system.

The "historical blacks" were long-term fighters in the cause of integration. Their style was different as was their experience, than that of the "new leaders." They had a long history of struggling for better educational opportunities. Their backgrounds were in the churches and traditional civil rights organizations. They were a moderate force in the coalition and bridged the gap between the "new leaders" among the blacks and the west-side and inner Northeast white liberal groups.

Based on information from the interviews, a pattern of decision-making emerged in the coalition. The "westside liberals" and "new leaders" were the leaders in forming the agenda, pushing issues, and strategizing the organization's direction. The "new leaders" and North/Northeast "old-timers" voted together on the issues while the "westside and inner Northeast liberals" were the other voting 
bloc. The mediators were the bi-racial "human relations professionals" and "historical leaders" who moved between the two voting blocs to resolve the conflicts. (Interviews, $7 / 14 / 80,10 / 13 / 80$; see Appendix $C$, question on roles)

The Task Coordinating Committee, which reviewed all sub-committee work and then referred it to the whole coalition for final action, had representation from each of the subgroups, but the "new leader" blacks were the majority. holding seven of the fourteen committee positions plus the support of two representatives from the North/Northeast "old-timers." The experiences and perspectives of individual members and their influence on the direction of the Coalition needs to be included in the analysis of the policy intervention by this community organization.

\section{Factors Shaping Community Organization} Intervention (Rothman, 1968)

\section{Goal Categories of Community Action}

The two official goals of the Coalition were adopted at its first meeting.

1. To identify common concerns of the community in connection with desegregation in the Portland School District. . . . the goal being to insure equal educational opportunities to maximize each child's potential.

2. To request of the Portland Public School Board a complete statement and analysis of desegregation policy and practices from 1965 through 1977 in order to enable the coalition to realistically make recommendations to the Portland Public School Board. (CCSI minutes, 9/1/77) 
Rothman identifies two kinds of goals in community organization models: task and process. A task goal, as defined by Rothman, is "the completion of a concrete task or the solution of a delimited problem pertaining to the functioning of a community social system" (1968, p. 477). The second goal of the Coalition was a task goal. The Coalition planned to develop recommendations for the Jefferson situation and then, study the entire desegregation program's practices. Process goals are "concerned with a generalized or gross capacity of the community system to function over time" (1968, p. 478). The Coalition's first goal, to ensure equal educational opportunity, is more of a process goal. The Coalition's goals reflect the social reform model of community organization. (See Figure 5.) The Coalition wanted to modify the existing desegregation policy through its study and recommendations. The reason the coalition pursued this task was to ensure equality of educational opportunity, a "process," a social action goal which in the long run involves a "shifting of power relationships and resources." However, the Coalition did not see itself as making "basic institutional changes," but "problem-solving a substantive community issue" which was affecting the minority community. (Rothman, 1968, Definitions, p. 477) Seventeen out of the twenty-nine coalition members interviewed listed the task goal as the major goal of the Coalition. Other members were divided among three 


\section{PRACTICE VARIABLES \\ 1. Goal categories} of community action

\section{Assumption} concerning comnunity structure \& problem conditions

3. Basic change strategy

4. Characteristic change tactics \& techniques

\section{Salient practitioner roles}

6. Medium of change

7. Orientation towara power structure

8. Conception of constituent population \& role

9. Assumptions regarding intereats of community subparts

10. Conception of the public interest
Shifting of power relationships resources: basic institutional change. (task or process goal)

Disadvantaged populations, social injustice, deprivation, inequity.

Crystalizization of issues \& organization of feople to take action against enemy targets.

Conflict or contest confrontation, direst action, negotiation. coalition

(Social Reform) *

Task goal: ----t-social provision
study \& make for disadvantaged recommendations group (task goal). for change of policy.

Inequity -.--...-- Substantive social problems * disadvantaged populations.

Coalition - populations.
politics of coalition of concerned interests.

Research: -.-.- Employment of

\begin{tabular}{l|l} 
Research: & - \\
fact-finding & facts o persuasion
\end{tabular} \& recommenda- to apply pressure tions for on appropriate change decision-making bodies.

Activist-advocate agitator, broker negotiator, partisan.

Manipulation of mass organizations political processes.

Power structure as external target of action: oppressors to be coerced or overturned.

Population as
victims; role as employers or members.

Coalition members both acted for others, but also had constituent members.

Conflicting interests which are not easily ieconcilable: scarce resources

Reconcilable -- -- Interests interests reconcilable or in conflict.

Reality-Individualist...- Realist-

Individualist.

Figure 5. Comparison of the community coalition with two models of community organization practice. (Rothmar, 1968)* 
additional goals: quality education, integration without undue stress on blacks, and equity in desegregation.

Equal educational opportunity, the Coalition's process goal, had three components: equity, quality education, and desegregation/integration. For some, equal educational opportunity was providing quality education for all children. However, there was growing concern that desegregation schooling did not mean quality education for black children. (Interview, 6/17/80b; Oregonian, 11/16/80, P. B1, 11/20/80, p. BI) There was no evidence of increased achievement in test scores and there was evidence of disciplinary problems, e.g., the "out of compliance decision" by the federal government in July, 1977 over discriminatory disciplinary practices (Oregonian, 11/16/80, p. B1).

Some Coalition members had a commitment to integration, but only if it was accomplished without undue stress on black children (Interviews, $7 / 25 / 80 \mathrm{~b}, 7 / 24 / 80,7 / 21 / 80,9 / 15 / 80$ ). Finally, there was support of desegregation programs, but the overriding issue became how they were desegregated. Is the desegregation plan equitable to all students? The coalition members and the black community did not think one-way busing was equitable (School Desegregation in Portland, Oregon , 1977; Interview, 7/21/80; Oregonian, 11/12/80, p. 1). Four hundred citizens who participated in the coalition's forum series listed inequity as the major issue in school desegregation in Portland (Coalition Report, 3/18/78, p. 1). 


\section{Assumptions Concerning Community Structure and Problem Conditions}

Coalition members felt very strongly that inequity in school desegregation was the substantive social problem. The policy was inequitable because black children bore the greatest burden. The social reform model assumptions about the community structure "include both substantive social problems and disadvantaged populations." The Coalition was closer to the social reform model as few members described the community as "comprised of a hierarchy of privilege and power, the social action model orientation" (Rothman, 1968, pp. 477,488$)$.

The Coalition assumed that if it documented the inequity, the board and superintendent would change the inequitable policies. As the research committee began to document the degree of "scattering" among minority children, Coalition members felt the practices were so clearly inequitable that once documented, it would be incumbent upon the school district to changes these practices. (Interviews, $7 / 10 / 80,6 / 19 / 80 b, 6 / 18 / 80 a)$

\section{Basic Change Strategy}

The basic change strategy of the social reform model "involves the coalition of concerned interests" (Rothman, 1968, p. 488). The Coalition exemplified this basic change strategy. The process of building an interracial coalition 
began as a result of the three invited community organizations extending an invitation to all community groups to participate in the study. These three organizations saw the need for broad-based community involvement in this study. (Interviews, $6 / 10 / 80,6 / 11 / 80 a, 6 / 11 / 80 b, 6 / 17 / 80 b$ ) one hundred and ten people came to the first meeting of the Coalition. They selected the name, Community Coalition for School Integration, because they wanted a name that was "progressive and positive" (Interview, 6/17/80b). The Task coordinating Committee which functioned as the executive committee: was broad-based, reflecting racial, residential, and occupational diversity.

The Coalition's first task was to develop a group that could work together. It was one thing to say that this was an interracial organization; it was another to work as one. Several Coalition members commented that initially there was distrust, which had to be overcome, between blacks and whites, but also between the east and west-side whites. One approach to this issue was to select two co-chairs, one black, one white, for each committee. Two-way communication on the issues took time because many whites were unaware of the changes in Albina schools. Blacks were insistent that the whole community be involved in this study because it was a city-wide problem, not just a problem of the black community. Interview, 6/11/80a, $6 / 11 / 80 b)$ 
One perspective on the group process was described in

the following:

The group was varied in age, ethnic background, economic background and geographic location. Therein lay its strength. Therein, also lay the difficulty of coming together as separate individuals with many different perspectives and experiences. The dynamics that operated within that organization was really thrilling to observe. [In the beginning, a simple planning of a panel seminar at a high school would take four hours for the Community Involvement Committee. And then we got so that we could do our work in an hour's time which felt like a reasonable length of time.] But for volunteers to go week after week, sometimes twice a week, and spend four hours an evening. You understand there was something very significant occurring or they wouldn't have done it for eighteen months.

Credibility had to be established. The process of examining an issue and arguing the issue rather than getting angry at the person who was taking an opposing position to yours--that was a very important learning process. Learning the difference between feeling and facts--that feelings are facts, as well as data. And the people who were accustomed to thinking and speaking in terms of feeling caine to value those folks who could translate their feelings into communicable information that could become part of the report. If you are going to permit someone to communicate your feelings, you have to trust the $\mathrm{j}$ rsson who is doing the translation. (Interview, 7/10/80)

The coalition also established a democratic decisionmaking process. The members wanted the entire body to make the final decisions. The working committees would submit recommendations to the Task Coordinating Committee which in turn would ask the entire coalition to take final action. The Coalition saw the need to "educate ourselves first, then others in the community" (Interview, 6/17/80b). The decision-making process allowed much of the work to be done 
in the committees, but the entire membership would participate through the final vote. This process allowed the Coalition to act as one voice when making outside presentations.

A coalition representing diverse interests involved trade-offs as well as listening to other people's points of view. There was complete agreement among interviewed Coalition members that the process was one of the most democratic of any group. The meetings were long because everyone was heard. When it came time to vote, especially on controversial issues, people were either ready to compromise or to accept the results because their voice had been heard. Also, individual groups were free to pursue their own goals outside of the coalition. If the coalition could not agree on an issue, an individual or group might decide to work on it.

Characteristic Change Tactics and Techniques

Social Action (p. 477)

Change tactics are: confrontation, direct action or negotiation.

(Rothman, 1968)

The Coalition's strategies generated much of the debate and controversy over style and substance in the greater community. Was the Coalition composed of social
Social Reform (p. 488)

Change techniques use in large measure campaign tactics, the employment of acts and persuasion to apply pressure on appropriate decison-making bodies. 
activists or a more traditional group of reformers? One board member characterized them as proponents of the "politics of confrontation" (9/8/80). For Coalition members, they were operating very much within the reformist mode of change. The Coalition believed it was practicing consensus politics.

The test for strategy selection, according to one member, was "Is this strategy relevant to our goals?" (Interview, 6/19/80c). The strategies the Coalition employed were: research (data gathering and analysis), community involvement, media suppport, and lobbying.

Research

The Coalition was committed to a comprehensive and high quality research effort. It hired two research staff, both with previous experience with desegregation. One had worked as a research assistant on a year-long participantobserver study of the first year of desegregation in a Portland elementary school. The second person had been involved in a desegregation struggle in an eastern city school system, as well as having worked for integrated housing as part of a national movement. The Research Committee divided into subcommittees to analyze all parts of the desegregation program. The fout major subcommittees, Legal, Demographic, Policy and Plans, and National followed a research outline that targeted the following areas 
for study:

1. Desegregation efforts of other cities--specifically, role of the community;

2. Legal constraints--federal and state regulations;

3. Administrative Transfer programs;

4. District magnet programs;

5. Multi-cultural preparation;

6. Staffing;

7. Early Childhood Education Centers;

8. Curriculum--elementary, middle school, and high school; and

9. Housing.

In order to evaluate the desegregation program, the coalition had to know what the district knew plus be knowledgable about the national desegregation efforts. As one member explained, "You can't advocate for change, if you don't know what you want to change" (Interview, 6/10/80).

In addition to the work of the staff and the Research Committee, community forums were a source of information regarding people's experiences with desegregation. Forum participants' comments were part of the data base.

The Coalition was dependent on the school system for all local school data. There were some problems obtaining adequate data. As one school district employee explained:

Until recently, the school district had set up no program to evaluate the effects of desegregation on student achievement. The reasons . . were myriad. 
The objectives of the desegregation program were primarily social objectives, he said. It was probably assumed in the first years of the program that its effectiveness (in. improving black achievement) would not be so great.

I also think there was an honest fear that if you began emphasizing achievement, then that might be used as a reason for terminating the program.

For the past two or three years, the school superintendent really wanted to have a testing program, but we found ourselves in such a data disarray that we couldn't do it. (Oregonian, 11/20/78, p. BI)

The "disarray" grew out of several problems. (1) The district had no city-wide testing program, other than the METRO Tests, a locally developed achievement test. These tests were given only at grades 3,8 , and 11 and could not be used for desegregation evaluation because they did not follow students from one grade level to another. (2) Also, each of the three administrative areas has used different tests at different times of the year, which makes comparison impossible.*

(3) Another problem was in the area of keeping adequate records. The district which was decentralized into three administrative areas, had no student numbering system so that individual students could be identified and followed as they moved from one school to another. (Interview, $7 / 23 / 80)$

\footnotetext{
*Use of a new measurement system began district-wide in 1980. A three-year data base has been established which wili be available for analysis in the fall of 1980, so that achievement data can be used in the future. Ooregonian, $11 / 10 / 78)$
} 
The Coalition, with the assistance of the district, developed a survey which an independent research firm used to interview all participants in the Administrative Transfer program. In sum, the Coalition's research was based on analysis of local school district data, community input, review of desegregation research nationally, legal precedents, the Administrative Transfer survey, and a review of all aspects of the district's desegregation programs.

The Coalition's recommendations were resubmitted for review to a series of community forums in the fall of 1978, as well as to the participating organizations. The entire Coalition voted on the final recommendations for the board in November, 1978. Additional discussion of this process is found in the section, Assumptions Regarding Interests of Community Subparts.

\section{Community Involvement}

The second major strategy of the coalition was to involve the entire community in an examination of past desegregation programs and a decision on the direction of future desegregation programs. Community education and community involvement were the two approaches pursued in order to generate public awareness of and support for the need to change the situation. The Coalition held two series of community forums. The first series involved fifteen meetings and approximately 400 persons participated. (Coalition report, 3/78) The purpose of these 
forums was to gather information from the community as to the nature of the problems with desegregation programs, and about peoples' views of what the priorities in desegregation should be. The four priorities they named were inequity, interracial understanding, quality education, and neighborhood integrity. (Equity for the $80 \mathrm{~s}, 11 / 27 / 78$, pp. 128-29) The second series of forums was held in Fall, 1978 at twelve schools. The coalition presented various desegregation plans for community response. Of the various options, a one-year transfer program received support from $59 \%$ of the white participants and $70 \%$ of the blacks. For pairing of grades $1-4$, white support fell to $42 \%$ "acceptable" and 55\% "unacceptable," as compared to black support, 728 acceptable. On pairing grades 5-8, white support rose slightly to $45 \%$ "acceptable," but $50 \%$ still found it unacceptable. The black figures were 76 : acceptable and $18 \%$ unacceptable. (Equity for the 80s, CCSI, 11/27/78, p. 142) The Coalition recommended a combined pairing approach, but it acknowledged that the one-year required transfer idea received significant support from participants who attended the public forums.

Under either program, a concept which received broad public support--the concept of keeping students from a particular neighborhood together as they go through school--would pertain. Considering the two from a purely economic view, the pairing plan, involving far fewer schools than the one-year plan, is preferable because transportation costs would lower. (Equity for the 80 s, $11 / 27 / 78$, p. 85)

Transcripts of both series of fordms are contained in the 
appendices of the Coalition's final report, Equity for the 80s (1978).

Another way the Community Involvement Committee involved the community was through social gatherings. The Coalition sponsored two parties on May 19, 1978 and November 4, 1978. Four hundred and fifty people attended the first party. The parties were an opportunity for Coalition members to work together on an informal basis. Several people commented that washing dishes was a great way to work out geographic and ethnic differences (Interview, $6 / 19 / 8.0 \mathrm{~b})$. The parties attracted city and county politicians. The party was an opportunity for community-building among Coalition members, as well as with the broader community.

The Community Involvement Committee also established a speaker's bureau which provided speakers to organizations to explain the study the coalition was doing and to solicit support from various groups as the Coalition prepared its final recommendation.

Media

A third strategy involved work with the media for extensive coverage of the Coalition's activities. Part of the community education process was to make all citizens aware of the issues in desegregation. Coalition members believed one of the problems was that desegregation choices 
were not openly discussed in the past. One role the coalition played was to expand the discussion both in terms of the number of participants as well as the scope of the issue. The media was an important part of this strategy. Four newspapers, the Oregonian, Oregon Journal, Portland Observer, and Willamette Week, covered the Coalition. The television stations also regularly covered Coalition meetings and forums, and did a special series on the issues. The Portland Observer offered the most continuous coverage of the coalition in articles and editorials. The oregonian edication reporter was released from regular assignments for four months to research indepth the desegregation program. (Interview, 9/21/80) The Oregonian carried a twelve-part series analyzing desegregation in November, 1978, right before the Coalition presented its report to the board. One television channel showed a four-part series on its evening news in February, 1978, focused on desegregation, and on educating the public about the community forums. During the time from November, 1978 to January, 1979, there was extensive coverage by the newspapers, television, and radio on the Coalition's recommendations. Willamette Week ran lead stories for three weeks in December, 1978. The Oregonian and Oregon Journal gave front-page coverage as well as editorial support to the work of the Coalition. In January, 1979, a local television news analyst did a three-day series on the evening 
news which was supportive of the Coalition. The news media very consciously tried to show the school system the amount of community support behind the coalition. (Interview, $9 / 19 / 80)$.

\section{Lobbying}

Coalition members question how effective their lobbying efforts were. In fact, some coalition members prefer to describe their efforts as more persuasion than lobbying. One coalition person said, we were informing people to get support $(7 / 25 / 80 a)$. The Community Involvement Committee met with city council and county commission members several times to keep them advised of their progress, as well as to solicit support for their proposals (Community Involvement minutes, April, 1978). Small groups also met with school board members between Spring and Fall, 1978 to apprise them of their work. Several school district staff were asked to read draft reports for discussion and comment. The lobbying/persuasion effort was fairly low-key in the attempt to keep all the people aware of the coalition's study and recommendations. (Interview, 9/15/80)

The Coalition did want the city and county politicians' support and endorsement of the final report. They also informed and asked for support from member organizations. It was a "soft" approach of communicating and sharing ideas with the board--in essence, "cultivating the board." (Interview, $7 / 14 / 80,8 / 6 / 80$ ) 


\section{Other strategies}

The primary strategies of the Coalition characterize it as a "social reform" organization. However, some of the tactics the Coalition considered but did not adopt reflect more of a social action approach. The direct action tactics of a boycott and legal action were considered after the board's rejection of the schonl pairing plan. On a March, 1979 visit to Seattle, the Coalition team learned that a successful boycott by blacks had contributed to that school system's adoption of a mandatory plan (Interview, $7 / 16 / 80)$. Legal research was done to explore the possibilities of a lawsuit, but the conclusion was that it would be difficult because of the district's record of voluntary desegregation (Interview, 7/16/80b). The Coalition as a whole decided not to take legal action, but several individuals did file a complaint with the office of Civil Rights in January, 1979 regarding the "disproportionate burden" issue. (See Impact chapter.)

Because of the policy that individuals and organizations could pursue their own objectives in desegregation, the Coalition decided not to play an "ombudsman" role of trying to respond to all the concerns of the black community regarding education. The fear was that the coalition would become too diffused from its major goal. Also, that it 
would lose credibility if it were constantly getting sidetraced on other issues.

There were two vacancies on the board between January, 1978 and November, 1978. The Coalition did not back candidates, but a small group of Coalition members supported a black candidate with a compatible educational philosophy. They were not successful in getting their candidate appointed because the board selected another black candidate. The selection process indicated, however, the divisions within the black community and that no black would represent the entire biack community.*

The real. struggle over tactics was more a matter of tone and style. One faction within the coalition wanted to use confrontational tactics--"to embarrass the Board publicly" (Interview, 6/16/80). They thought the record of abuse was perfectly clear. The struggle was between confrontive and conciliatory styles. Some wanted to be clear and indicting--to call the administration "racist." Others sought a more conciliatory model of communication and advised against "burning our bridges" (Interview, $6 / 18 / 80)$. These differences were not solely based on race, since many of the North/Northeast "old-time whites" agreed with the "new leader" blacks in assigning blame to the

*For further discussion of this appointment struggle, see Willamette Week, $10 / 2 / 78$ and Portland Observer, $8 / 10 / 78$, $8 / 1 7 \longdiv { 7 8 , 8 / 2 4 / 7 8 \text { . } }$ 
school system. Some "historical blacks" agreed with "westside white liberals" that they could still work with the school system (Interviews, $7 / 10 / 80,8 / 11 / 80,6 / 19 / 80 \mathrm{~b}$ ). Some Coalition members liked the confrontive mode, while others liked a more conciliatory role. Regardless of individual preferences, the coalition agreed that it had to confront the district and board with the findings of the study and advocate strongly for its recommendations.

\section{Salient Practitioner Roles}

Rothman (1968) identifies various roles a community organizer employs while working in an organization. This study asked Coalition members to describe the role(s) they played. There is overlap as several people described themselves as playing more than one role. Under the social action category, five described themselves as activistadvocates, two as brokers, and one as a negotiator. Under the social reform category, eight described themselves as coalition-builders (mediators) and five as fact-gatherers.

In addition to these categories, four people saw their role as that of "facilitator," two people as "interpreter," and about six people played an "organizer-plannerstrategist" roie. The mediators-facilitators-negotiators played a critical role since they spent much of their time listening to the different opinions of the members. Their task was to "calm people down, to bring people back 
together, and to help people with opposing styles to hear each other" (Interviews, 7/10/80, 7/14/80, 7/25/80b).

Many Coalition members felt the leadership played a significant role as "the glue that held the coalition together." At meetings everyone had a chance to speak. (Interview, 6/11/80b; Willamette Week, 12/25/78) The diversity of individuals and organizations made it imperative that everyone work together on the key issues. One way the Coalition encouraged its members to become involved was through committee assignments. That way, each person could learn about the issues firsthand at the committee level and then reconsider issues at the full coalition meetings.

An overriding characteristic of the Coalition was its commitment to the democratic process. It served as an alternative model to the school district in that it allowed the community and its membership to determine the agenda. Some people voiced their opinions strongly, but "people eventually put away their private agendas, became part of the coalition process and struggled to reach an acceptable compromise on our Board recommendations" (Interview, $7 / 10 / 80)$.

\section{Medium of Change}

Activists in the social action model "create and manipulate mass organizations and movements and influence 
political processes" (Rothman, 1968, p. 482). The coalition-builàer "manipulates voluntary associations and legislative bodies" (Rothman, 1968, p. 488). The Coaition addressed two arenas: formal organizations in the political process, and voluntary associations.

"Manipulation of formal organizations and of data, the social planning model" was primary in the Coalition's operation (Rothman, 1968, p. 477).

Coalition members were optimistic about this approach because the school board had accepted and implemented the Schwab committee report. Its line of reasoning was:

If the Coalition does responsible research, the board will accept our recommendations. The Coalition is a responsible, commited group of citizens similar to those who researched and wrote the Schwab report. (Interview, $7 / 10 / 80$ )

Coalition members met with board members and district staff periodically in an attempt to keep everyone informed of its progress. (Interview $6 / 18 / 80 c$; Coalition minutes) They were committed to play by the rules, i.e., submit reports on time (Interview, 9/15/80).

In retrospect, some coalition members noted the political naivete concerning its research approach (Interview, $6 / 19 / 80 \mathrm{~b})$. The Coalition was not prepared for the "politicalness" of the process (Interview, 7/21/80). It didn't understand the need for more people with clout to be involved (Interview, 6/18/80c). Although Coalition members met with school district staff, board members, and city and 
county politicians, it decided not to lobby or negotiate with the board prior to the final recommendations (Interviews, $6 / 17 / 80,7 / 21 / 80)$.

Some Coalition members may have been politically naive. Others, however, decided to support the research and recommendation approach as the most viable at that stage of events and recognized that community support would be critical for the acceptance of the report. The Coalition did not consider the social action model of "influence the political process" until after the board's rejection of the school pairing plan. (See Chapter VI for further discussion.)

Not all Coalition members supported the research format as a way of changing the board's policy. However, the major focus of the Coalition from January, 1978 to January, 1979 was on collecting and analyzing data. The Community Involvement Committee and the Task Coordinating Committee recognized the need for support from influential groups for their final recommendations. Although the Coalition received support from a variety of community groups, there were some important community segments missing.

Every successful desegregation plan has happened because city and business leadership gave it their full support (Kirby et al., 1973). Although the Coalition sought support from these groups, it received only limited 
endorsement from the business, political, and religious community segments. There were individual exceptions. Two city commissioners did support the Coalition's report with written testimony before the board; the Chamber of Commerce joined the Coalition; and the regional ecumenical religious body endorsed the Coalition's findings. Other people with power and influence were noticeably absent. one coalition member suggested that business, political, and religious ieaders speak out only in crisis situations where harm may occur in the community (Interview, $7 / 21 / 80)$. The Coalition documented the problem but evidently it was not perceived as beirg at the crisis stage. Another possible explanation was that the business and political community was generally supportive of the board and superintendent. "The superintendent didn't let anyone know he had a problem," explained one Coalition member (Interview, 6/19/80c). In addition, the board's and superintendent's attitudes about the Coalition made it difficult to approach some business people (Interview, 6/19/80b). Some members of the business community did contribute financially to the work of the coalition, but did not publicly support the Coalition report.

The Coalition was most successful with its "manipulation of voluntary associations" (social reform model)--in essence, its own member organizations. The Coalition was able to get support for its findings and recommendations 
from most of its member organizations. Not every organization supported the school pairing concept. Several groups supported the overall value concepts of the report, but not the specific recommendations.

\section{Orientation Toward Power Structure}

The historic development of the desegregation issue in Portland was an important factor in how members viewed the power structure. The Coalition began with the research change strategy because that was what the board asked them to do--study and make recommendations about the Jefferson situation. Second, they adopted the research strategy because the Schwab committee report had been accepted. But unlike the Schwab report which began with a blank slate of desegregation accomplishments and was able to make recomendations about what to do about segregated schools, there was a thirteen-year history of desegregation programs for the coalition to evaluate. The school system, the families, and the neighborhoods involved in the desegregation program had been affected by the experience. The board and school district generally were pleased with their progress. Some black parents had begun to question its success, while others continued to support the programs. (Interviews, Oregonian, 11/10/78-11/20/78, Portland Observer) 
How people perceive the power structure has a great deal to do with their previous experiences in trying to make changes in the system. Many Coalition members ascribed to the social reform orientation. They saw the power structure as that of "gate-keeper" and that its power center could be influenced through persuasion or pressure. In contrast, the social action model sees the power structure as an external target of action. The "oppressors need to be coerced or overturned." Some coalition members and, later, the Black United Front shared this view of the Portland power structure. (Rothman, 1968, p. 483)

Portland has had considerable citizen involvemenc in city politics during the 1970s. Neighborhood associations have been involved in community development plans; the citizens advisory committee of the Downtown plan and numercus City Club reports all have influenced politics and policy. The success of the Schwab committee and experiences with city-wide citizen action led coalition members to see the power structure, the school board and superintendent as open to influence. Some coalition members were skeptical and thought there was a need for stronger action.

Although the Coalition began with this social reform orientation, it changed during the process of persuading the board. Coalition people began to lose confidence in this approach. One member commented on the "frustration 
because no one took the concerns seriously." Neither the board nor superintendent wanted to discuss "how do we make it work better?" (Interview, 6/19/80b). People with City Club and Schools for the City background had successfully used persuasion in past approaches to power structures. They were s'iprised when the board expressed resentment over their criticism when their attitude seemed to be-we don't want to answer questions about desegregation policy. (Interviews, 6/19/80b, 7/10/80)

Although the persuasion approach was not successful with the board, Coalition members offered these explanations for that failure. The power structures does not respond the same way to the black assessment of the problem, as it does to a white assessment. (Interview, 7/21/80) The interaction with the hoard was rot a static process. Perceptions were constantly in flux. One board member felt that the Coalition was not interested in discussions because the board was not able to dialogue with Coalition members (Interview, 9/8/80). Board members were not accustomed to the independent, adversarial style of the Coalition. Coalition members felt that the board and superintendent were threatened by the differences in style. The interactions quickly became an issue of personalities and positions. One board member believed this happened because two or three schcol system people were interacting with a core Coalition group on the issues, and that the discussions 
and decisions became more a matter of personality than the issues involved. Increasingly, the Coalition described the board and administration as "arrogant, paternalistic, entrenched, unresponsive and close-minded" (Summary of interviews, CCSI).

Coalition members began the study assuming that the school system knew what it was doing in desegregation. As information became difficult to obtain and exrors in school data were revealed, respect for the district staff eroded (Interview, 6/17/80b). For some Coalition members it increased their feelings of paranoia--the district had deliberately set out to destroy the black community. Other Coalition members, who assumed the board was composed of liberal, progressive people, saw a power structure which wore blinders and did not look at the consequences of its actions. (Interview, $8 / 6 / 80$ )

As the recognition of the political nature of the educational process evolved, people grew dissatisfied with Coalition actions. Some were upset at the compromises made over the research report in order to have acceptable recommendations for the board (Interview, 7/25/80a). Others hoped that the more powerful whites (those with past experience of influence with the district) would accomplish the needed changes. Their hope was replaced by anger when that did not happen. Coalition members, although recognizing that the power structure was closed to their questions, 
still hoped the board would accept all its recommendations. The Coalition hoped its unity, strong community support, and research findings would be enough to convince the board.

One newspaper report commented:

clearly, the coalition has a couple of things in its favor. While Portland long has possessed its fair share of racists, such people are not currently in power on the school board. A close observer suggests that the 'principal motivation in board members' decisions on such an issue is "what's basically acceptable." And it's clearly not socially acceptable to be perceived as racist at this point in Portland's history. . . Additionally, some moralists will say the Coalition has a clear moral issue on its side: the unfairness of requiring one community to travel to get an education without making a similar requirement of others.

Social acceptability and moral issues, however, may not be enough to get the coalition the result it wants. (Ronald A. Buel, "The Politics of Pairing," Willamette Week, $12 / 11 / 78$, p. 6)

Some Coalition membars felt "The district may have underestimated us because we were nice people. Sometimes we worry too much about being nice" (Interview, 6/12/80). The Coalition pursued the nice, liberal, progressive game of change with the board as its target and then did not win all that it wanted.

\section{Conception of Constituent Population and Role}

The Coalition moved in and out of the Social Action/ Social Reform definition of its constituent population, the "community at risk." One view was that the community constituents were a population "suffering at the hands of the broader community and thus in need of support" (Rothman, 
1968, p. 484). The black at-risk population was the primary target of the Coalition's advocacy efforts. However, for some coalition members, the entire community, black and white, was affected by the inequitable desegregation policy. Coalition members advocated for their own children as well as the community's children.

Over two-thirds of the coalition members interviewed identified the black community as the population at risk. The Coalition began in order to redress the grievances against the black community. As the research findings were shared about one-half of those interviewed identified the entire community as the secondary target. They argued that the entire community benefits from desegregation and that whites need integration. So, a secondary target was advocating for an integrated society. (Interview, 6/19/80b)

The Coalition was not viewed as paternalistic in their relationship to minority constituencies. In constrast, the Committee of 100, Schwab committee, and Schools for the City were groups "doing it for or acting on behalf of blacks." Acting on behalf of the population at risk is more in the tradition of the social reform rivdel. "A common mode of social action involves activity by a group or coalition of interests which acts vigorously on behaif of some outside client group which is at risk" (Rothman, 1969, p. 488$)$.

The Coalition worked hard to advocate for its own 
constituencies. One perspective was that the black community, through its involvement in the Task Coordinating Council and Research Committee never gave up control or surrendered its advocacy for black children. (Interviews. $7 / 21 / 80,7 / 25 / 80 \mathrm{c}, 9 / 15 / 80)$. This reflects the social action model, "the client group, whether employers or constituents, is in the position of determining broad goals and policies" (Rothman, 1969, p. 487). At the same time, the blacks needed white support ind advocacy (Interview, $7 / 21 / 80)$. Another perspective was that whites did advocate with blacks and for black children, but they also saw desegregation as a community problem. Many of them were advocates for integration, as well. (Interviews, 6/19/80b, $7 / 10 / 80,7 / 25 / 80 a, 8 / 6 / 80)$

\section{Assumptions Regarding Interests} of Community Subparts

The social action model assumes that interests among community subparts are "at variance and not reconciliable," while the social reform model assumes that the "interests may be reconciliable or in conflict" (Rothman, 1968, pp. 485, 488). The majority of the Coalition people interviewed said that conflicting interests were reconciliable which fits with their orientation to the power structure as being permeable to persuasion.

Internally, the members of the coalition found they were able to reconcile their differences as a group. There 
were several reasons for their ability to reconcile different interests witisin the Coalition. The organization of the Coalition provided an escape route. Organizational members could present their own perspective, but if their organization disagreed, they could withdraw from the vote. Despite their own preferences, members worked as a group on desegregation issues. (Interview, 7/30/80)

All the Coalition members joined because "somathing had to be changed." The staff and committee members used the community forums to identify underlying values that people shared and then built a value consensus on the issue of equity. Equity was a value both blacks and whites supported. (Interview, 7/25/80d) Differences were negotiated within the coalition. Whites were interested in integration and multi-racial experiences; blacks were interested in quality education. The whites discovered that blacks were not opposed to integration, but not at the expense of destroying black neighborhood schools. (Interviews, $7 / 25 / 80 b, 7 / 25 / 80 c)$ Given these different priorities, the hottest debate focused on the recommendation about school pairings at a November, 1978 Coalition meeting. The recommendation read:

"The district should pair each of the seven predominantly minority schools in the district with one or two predominantly white schools in a manner that will comply with state guidelines on racial balance." The League of Women Voters representative said that pairing with only one or two schools was 'too limiting' and that she thought more students should have the opportunity to attend integrated schools than 
such a system would allow.

It was a black teacher who responded most forcefully to that motion. 'I'm more interested in the welfare of the children who are being scattered all over the city. When black children are divided up, the achievement level is lower. When people are together, more people support each other. I'm not interested in trying to give all the white people the experience of having one or two in their school.' (Willamette Week, "Politics of Pairing," 12/11/78, p. 6)

Although Coalition members were committed to a resolution of conflicting interests between the board and themselves, they increasingly realized it was a one-way street. The board was not able to hear the citizens on this issue. (Interview, 6/19/80a) Another member described Portland as a city of "civilized politics." The modus operandi is not to admit to probiems, but to resoive situations in a gentlemanly way. (Interview, $6 / 17 / 80 \mathrm{~b}$ ) The Coalition did play by the rules of the game, but not always in the style to which the school power structure was accustomed.

The board and superintendent were not used to being challenged by parents and other non-educators who were knowledgeable on the issue to be decided. The board was used to negotiating with teacher unions and other educational professionals. It also was accustomed to citizen advisory committees who were normally consulted after the fact and, in some instances, did not clearly understand the problems. For example, the Title VII, ESAA Citizen Advisory Committee responsible for desegregation planning, was unaware of the scattering and other issues the 
Coalition raised. If it had been informed or more involved, it might have asked for the kind of data the coalition obtained. (Interview, 6/17/80)

Portland's political style was not one of confrontation. As the Willamette wieek described the evening of the Coalition's board presentation:

It was a scene to remember. It was big-time racial politics come to Portland, a city that somehow had escaped the intense backlash and explosive fireworks that have come out of school integration in many other American cities. $(12 / 11 / 78$, p. 1)

A Coalition member describing Portland politics, said, "Most of the outs when they want to deal with educational issues, it's by way of appeal and appeasement syndrome. They appeal to the good will and knowledgeability of the insiders and the insiders accede to that if it makes them look good or if it's in their interests" (Interview, $6 / 17 / 80 b)$.

The kind of negotiation that characterized the coalitions' reconciliation of conflicting interests did not occur between the coalition and the school system. The coalition decided not to negotiate prior to the board presentation. It had chosen to persuade the board to adopt its recommendations by the strategy of an united front with considerable community support. The board and superintendent confronted with a pairing proposal that they considered politifcally infeasible, chose not to negotiate, but rather to accept all the Coalition's other recommendations except the one on 
school pairing. (Intsrviews, $7 / 31 / 80,8 / 12 / 80,8 / 27 / 80$, $9 / 8 / 801$

During that critical time in December, 1978, there was community recognition of the need for negotiation. The mayor offered his services as a mediator between the board and citizen's coalition, sensing trouble between the two groups would develop. The board meubers turned him down. 'It's a legitimate issue for the city to get involved in,' argued the mayor.

The board chairman--who up to a point welcomed the mayor's advice--said the mayor's services as a mediator simply were rot needed. 'The board didn't think that that was the best way to get at the problems,' said the chairman. (Oregonian, Forum, $2 / 1 / 79$, p. B7)

By this time, neither the board nor the Coalition wanted the mayor's involvement loregonian, Letter to the Editor, 2/79). The newspapers and television media maintained a level of support for the Coalition's recommendations. The media hoped by focusing attention on the need for the business and political community to back the desegregation proposals that such support might develop (Interview, $9 / 19 / 80)$.

The Coalition testified in response to the superintendent and asserted its willingness to negotiate (Coalition response, 12/18/78). The board, while emphasizing the common ground between the coalition and themselves, would not accept the pairing proposal (Interview, 9/8/80; Oregonian, 1/23/79). The board accepted the superintendent's judgment that the pairing plan would not work (Interview, $8 / 12 / 80)$. There was one vote for the Coalition's plan. 
The Willamette Week pointed out the board's dilemma: This political hot potato being dropped in their laps wasin't exactly welcome. This had been a rugged year for the board, with members under fire on a number of fronts. At one point, a petition was distributed to recall the board. And four of the seven members are up for election in April. (12/11/78, p. 1)

One board perspective was that the Coalition had failed to consider the "political sensitiveness" of the issue. The Coalition, by focusing on equity, represented blacks and whites already committed to desegregation, but it did not address the silent majority or white reactionaries who were not always supportive of desegregation plans. For example, the PTA was not able to support the pairing plan, although the PTA representative to the coalition personally supported it. (Interview, 6/19/80c: Willamette Week, 12/11/78). The board, on the other hand, focused on the voting public, the business community, and middle to upper income areas in Portland. The Coalition did not have enough of these kind of people participating to convince the board that a mandatory, school pairing program would not result in white flight. (Interviews, $8 / 12 / 80,9 / 8 / 80$ )

Conception of the Public Interest

Both the social action and social reform models' conception of the public interest is "realist-individualist." 
This view stems from the fact:

of having no control of, and little access to, a central decision-making apparatus in the community, and usually comprising a small minority of the population, special interest groups can only be effective confronting others, sometimes attempting to make ad hoc coalitions and alliances in the community market place. (Rothman, 1968, p. 486)

Two-thirds of the coalition members interviewed, described the coalition as representative of the public interest. For some members the Coalition offered a "vision for public education," whils others saw it as a public interest group with a special focus on education. (Interview, $7 / 10 / 80)$. Some felt it began as a special interest group, but moved to a public interest group as it recruited people from diverse backgrounds. Another perspective was that the Coalition represented special interests, people committed to desegregation, but made an effort to include all elements in the community (Interview, 6/2/80). The coalition did not include conservatives, pro-neighborhood school groups, the business establishment, and some segments of the black community. The coalition was composed of a number of special interest groups, but because of the nature of the issue, they joined together to work for their perception of the public interest. (Interviews, 6/11/80, $7 / 10 / 80,7 / 25 / 80 d)$

The issue was how to achieve equity in desegregation? The solutions needed support from the entire community. 
The reality in Portland was that whites were not concerned about desegregation since it was a voluntary effort for them, unlike the blacks' experiences. (Interview, 6/11/80; City Club report, 1980) The challenge the Coalition accepted was to open up the decision-making arena to the entire community on the implementation of desegregation. Working primarily with social reform tools, the Coalition tried to educate the community to the desegregation reality in Portland, Oregon before any changes could be made.

In the next chapter, the impact of the coalition as an advocacy organization and its recommendations on the school system and the greater community will be examined. 


\section{CHAPTER VI}

\section{IMPAC' OF THE POLICY INTERVENTION}

Did the intervention by the Coalition have any impact on the desegregation policy of the Portland Public Schools? In trying to answer that question, this study will look at short-term and long-term impacts on the board, school district, the Coalition, and the community. The focus of the impact analysis will be on changes in the formal rules of the educational system that affect children at risk (laws, regulations, court decisions, school district plans) and the educational practices affecting these children (service denials or implementation of mandated services). (Moore, 1980) The third area of analysis of the impact of this policy intervention is whether the advocacy organization altered the complex network of activities at the federal, state, school district, and school levels that critically shape services to children. The rationaie for this third criterion is that past research on educational intervention shows that for new laws and court decisions to be implemented, appropriate changes must take place in dozens of interrelated activities carried out by public officials and educators at the federal, state, school district, and school levels. 
A Carnegie Corporation report on Child Advocacy and the Schools (1980) points out that child advocacy has developed as one response to breakdowns in the implementation of educational programs for children at risk.

Advocates argue that implementation failure occur because laws are not vigorously enforced, because rigid organizations continue old habits in the face of new program ideas, because political pressurss at various points in the implementation process dash the promise of new programs. They argue that reforms will improve services to children on a wide scale only when vigorous independent organizations press the educational system to carry them out at each point in the implementation process, in each important activity in the network of activities that shapes services to children.

The Community Coalition for School Integration was an advocacy organization working to change the local school district's desegregation plan. It established two goals:

(1) "to ensure equal educational opportunities to maximize each child's potential through the process of identifying common concerns of the community in connection with desegregation" and (2) "to make recommendations to the School Board on needed changes in the desegregation policy, after an extensive analysis of the present desegregation plan" (CCSI minutes, 9/1/77).

The Coalition, as documented in the last chapter, did involve the community through (1) its own membership, (2) the two series of community forums, and (3) extensive media coverage in identifying the concerns and problems the community had with the desegregation plan. The 
Coalition also made recommendations regarding Administration, Student Transfer plan, Curriculum, Teacher Training, Student Discipline, Minority Hiring, Minority Teacher Placement, Integrated Housing, Advisory Boards, and Future School Board Relationship with the Coalition. The school board accepted all of the recommendations except the Student Transfer plan.

The school pairing section of the Student Transfer plan recommended:

The school district should use school pairing as the major means to accomplish desegregation/integration. The District should pair each of the seven predominantly Minority schools in the District with one or two predominantly white schools in a manner that will comply with state guidelines on racial balance. (Equity, 1978, p. 87)

\section{Initial Impact of Coalition Report}

Before exploring further the impact of the Coalition's recommendations, it is important to examine the board and district's response to the school pairing plan. Why was it rejected? Their rejection was a critical factor in the nature of the impact that the coalition's work had on the desegregation polizy. The student pairing plan was important to the Coalition's demand for equity in desegregation.

From the start, the Coalition had made it clear that the student transfer, or pairing recommendation, was the one it cared about, the crucial part of its report. (Willamette Week, 12/25/78, p. 1)

The superintendent provided the first indication of how the 
district viewed that particular recommendation. In his preliminary response to the Coalition's report $(12 / 11 / 78)$ he said "that the pairing idea appears to be a considerable overreaction in view of the extent of the problem it is intended to solve" (p. 25). He did not make a recommendation on the student transfer section, but added that "there are serious logistical problems with the pairing proposal that have to do with numbers of students, size of facilities, and racial percentages" (p. 24). His third area of concern was "the Coalition's proposal on pairing would reverse $a$ series of decisions that were approved by the Board after extensive community involvement and support" (p. 28).

The Coalition wanted to substitute its student pairing plan for all the desegregation plans in operation because it believed it was a more equitable plan. The coalition was concerned that upper grade level students from some Early Childhood Centers in Albina had no middle school of assignment. The irony, as the superintendent pointed out, that it was board policy regarding community acceptance of middle schools that converted two of the Albina schools into Early Childhood Centers rather than midale schools.

*. He said, "Both of these buildings were suitable for middle school use. The communities rejected the idea after much discussion. Both favored the establishment of Early Childhood Centers instead" (Memorandum: Superintendent 
Response, $12 / 11 / 78$, p. 28).

In addition to his administrative concerns over implementation of the plan, the superintendent did not think it was a plan, but more of an "ideological conviction." The fact that the Coalition did not name a single school demonstrated the political naivete of Coalition members, as they could not bring themselves to discuss which schools might be involved. (Interview, 8/27/80)

The Coalition responded to the superintendent's concerns on December 18, 1978. They challenged the superintendent's numbers, based on keeping the racial balance $70 / 30$ and on the total number of children involved in the schools, not just those who would be bused. The assistant coordinator of the coalition "refuted the Superintendent's statement that 15,000 students would have to be bussed to pair schools at a 70/30 ratio" (Portland Observer, 12/21/78, p. 1). The Coalition's estimate was approximately 5,000, a number based on a 50/50 ratio which is the district's current policy for the Albina schools. The coalition reasserted that the plan is workable, but the "bottom line is the willingness of the Board to assign white students to the Albina schools" (Coalition response, 12/18/68, p. 12). The Oregonian underlined the challenge:

The board must face an issue that the school administration has largely avoided--mandatory busing of white students to Albina schools to complement the present system of mandatory busing of many black students out of Albina. (12/19/78, p. B1) 
Part of the battle was over numbers. The Coalition claimed it would involve 5,000 students and the superintendent said 12-15,000 students would be bused. There were differences on how many minority students were "involuntary transfers." It finally came down to whose numbers did you trust. The Coalition (12/18/78) cautioned the board to look carefully at the district's statistics because they contained errors and were based on different racial ratios.

The Willamette Week $(12 / 25 / 78)$ analyzed the numbers argument.

The Superintendent's technique crumbles with a closer look. If you turn to the analysis provided by his own staff, and change the ratio away from 70-30 but keep all the schools under 50 per cent minority enroiiment, the pairing works out fine within the guidelines suggested by the Coalition.

There are 3,557 resident minority students in the predominantly black schools. In an analytical paper, the school district chose 14 westside shools with a total of 5,119 nonblack students and spaces for 6,375 . If you pair each of the predominantly black schools with two predominantly white schools, the numbers work out as follows: Bus half the black students, or 1,778 students. Bus less than half, or 2,147 of the white students, making the percentage of black students in the seven Albina schools 45.3 and the percentage of black students in the 14 white receiving schools 37.4 . In short, the arithmetic works if you make it work, and the superintendent's plan is nothing more than a straw man. (p. 1)

Meanwhile, the school board had not discussed in public its reaction to the Coalition's proposals. On December 29, 1978, the chairperson of the school board addressed the City Club on "The State of the Schools." The first public statement by a board member on the Coalition's plan 
indicated that the pairing plan was in trouble.

It appears that the pairing proposal of the Coali. tion has at least three principal elements which depart significantly from the School Board's integration program.

1. First, the Coalition calls for middle schools to be established without regard to the Board's community acceptance policy. The School, on the other hand, has not sought to impose middle schools over the opposition of the parents of the cluster, but to encourage parents to reorganize into middle school clusters to improve the educational programs.

2. Second, the Coalition calls for three midale schools to be established in Albina. We have placed middle schools on the periphery of Albina. Furthermore, under the coalition proposal at least two early childhood centers would have to be converted to middle schools even though the buildings are being remodeled for early childhood center use with full support of the local school advisory committee.

3. Third, the Coalition proposes that the attendance area of non-resident children (principally, majority children) at the Albina schools, including the early childhood centers, be mandatory. I do not favor the pairing proposals made by the Coalition. I do not think the pairing proposals are wise or likely to lead to greater equity or integration. (City Club, 12/29/78, pp. 18-19)

The philosophy underlying the district's emphasis on the voluntary approach to desegregation was underscored in this speech.

For example, in the absence of a court-ordered plan, it is not improper, and indeed it is wise, to place middle schools in locations, as we have done, where community acceptance has made the transition possible, on the periphery of Aibina, and then to ask that children, white and black, gather at these locations, by bus if necessary, for improved educational programs. (City Club, 12/29/78, p. 20)

On January 8, 1979, the school board voted to adopt all the resolutions regarding the coalition's recommendations, 
with the exception of student transfer. On January 12, 1979, the board chairperson sent a letter to the Coalition chairperson asking for the Coalition's participation in discussing how to "flesh out the general directions these resolutions indicate" (Letter from board chairman). The boa:=d had deferred action on the "pairing" proposal until the January 22, 1979 meeting so that they could emphasize the common ground they shared with the coalition (Interview, 9/8/80). There were two meetings with the Coalition between January 8 and January 22 so that the board could outline the resolution on pairing that they would present at their next meeting (Interview, 9/8/80). The headline on the front page of the oregonian (1/23/79) describes the action of the board: "School Board Rejects 'Pairing' Proposal."

The Portland School Board Monday night adopted a desegregation motion that rejects school pairing, proposes eventual establishment of middle schools in Albina, and relies heavily on present desegregation methods to bring about more equity in the district's school integration efforts. (p. 1)

Board resolution $\mathrm{x}-6184$, in rejecting the Coalition's pairing pian, stated:

The Board . . does not believe that the pairing proposal of the Coalition will either assure greater equity, increase interracial understanding, and improve educational quality, or further the District's integration programs. (Board minutes, $1 / 22 / 79)$

The board's resolution did address the "scattering" issue as it committed itself to "reduce substantially the 
scattering of minority students"; second, to "consider ways within the board's existing policy to establish middle schools for students in the Boise, King, ELiot and Humboldt schools attendance areas"; and to "increase attendance of white students in the later primary grades at Early Childhood Centers" (Oregonian, 1/23/79, p. 1). These were all issues raised by the coalition.

The Coalition had failed to convince the board that the pairing plan or mandatory assignment of white students to Albina schools was necessary to achieve greater equity. The board reaffirmed its commitment to work for greater equity within the framework of its own desegregation policy. A variety of reasons contributea to the majority vote of the board against school pairing. (One board member was absent that night, so the final vote was $5-1$ in favor of board resolution $\mathrm{X}-6184$.$) The board member who supported$ the coalition's pairing plan said it failed because Chapman and Airsworth, two predominantly white west-side schools, would have been bused to Boise, a predominantly black, east-side school. (Interview, 8/26/80) Past board decisions on midale schools had involved the same kind of problem: people were always interested in schools of higher status than lower status. The decision to pair schols involved having to make class and race assignments (Interview $8 / 26 / 80$ ). A Coalition member echoed this 
thought.

The board believes that the white community won't accept programs to end injustice if those programs involved busing white students into the black community . . But the more I know Portland, the more I think you sell white citizens short. (Oregonian, 1/23/79, p. 1)

Several board members who voted for the board resolution had accepted the school district's numbers and the superintendent's assessment of the unworkability of the plan (Interviews, $8 / 12 / 80,9 / 8 / 80$ ). One board member believed that the Coalition's efforts had created the right climate for the development of a cross-busing plan, but the support for such a plan never materialized from the community, newspapers or the board (Interview, 8/12/80). Another board member felt the survey data from Administrative Transfer program participants confirmed that the present plan was doing a good job, so why vote to support the Coalition's proposal which would involve major changes (Interview, $8 / 7 / 80$ ). The Corlition had not convinced another board member that they had done their political homework regarding the impact of pairing on the white community. This board member found the coalition to be politically naive because all. its emphasis was on equity and it ignored the previous desegregation efforts of the district (Interview, 7/31/80).

Once the board had made the decision, there was little room for negotiation. Each side continued to issue public 
statements which made "behind the scenes" or "off the record" conversations extremely difficult. (Interview, $6 / 2 / 80$ ) The board made the decision they thought was most viable and the Coalition objected. A Coalition spokesperson said in response to the board's decision, "If you try to give us a solution that doesn't involve white people actively, you aren't giving us an equitable solution. It is still one-way busing" (Oregonian, 1/23/79, p. 1). The impact of the board's rejection devastated the Coalition. Even though their other recommendations had been accepted, the membership felt it had failed to obtain a more equitable solution.

The first few months after the board's rejection of the pairing plan, the Coalition was directionless, angry, and divided. One member said, "we were exhausted and disappointed. The white liberals were angry and the blacks felt they'd been kicked in the face. Instead of turning on the board and the school district, we turned on each other" (Interview, 7/25/80). The Coalition had lost its staff and had no strategy ready for operation after the board's decision. All the attention and work of the Coalition had gone into the presentation of the report. (Interview, $7 / 14 / 80)$ Coalition members were burned-out and wanted to rest after the energy they expended during the two months of board presentations. (Interview, 6/10/80) Some members felt that they had accomplished what they set out to do-- 
research and recommend. Others, from the past months' experiences, concluded that it was essentially a political process. It was going to take more than study and facts to change the desegregation policy. There was a growing feeling that the changes would not occur with the present board. (Interviews, $6 / 10 / 80,7 / 25 / 80 \mathrm{~b}$ )

A television news analyst, in a January 23, 1979 commentary, assessed the school board decision.

In its resolution, the school board deals directly and firmly only with midale schools. It seems to promise a middle school in Albina and possibly a second nearby. Otherwise, the present program is not disturbed. In the lower grades, the burden of desegregation continues to fall on Black families. When the Board's hard commitments are sifted from its soft language, the resolution remains a middle school policy, which has been the centerpiece of district pulicy for ten years. The plan is likely to produce some marginal gains in desegiegation. It is by and large a midale school program, not a desegregation program. (Transcript from NBC local affiliate, Evening News, 1/23/79, pp. 2-31

The Oregonian had not supported the pairing proposal, but had favored the other Coalition recommendations. After the board decision, the oregonian urged the board and coalition to continue the negotiation on the basic issues. It criticized the lack of public discussion by the board on the substance of the proposals and suggested that in the future discussions on improvements in the integration program should be held in the open $(1 / 23 / 79)$.

Three weeks after the board meeting, another Oregonian article noted that the coalition still planned to push for 
'equity' in busing.

The coalition, which took shape in the summer of 1977 out of the anger of the black community over a plan to step up forced busing of black students, has to view the rejection of itis pairing plan as a setback. (2/11/79, p. D3)

Although the Coalition members were discouraged with the board's response, they announced that the Cualition "will continue to prod the district to re-examine its policies, perhaps enlisting support from the city and state. Right now, it's regrouping" (Oregonian, 2/11/79, p. D3).

The Coalition took several actions in February, 1979. They decided to reopen their membership which had been frozen since the previous fall. They redefined their mission to include monitoring of the district's performance on the resolutions. They reviewed complaints filed against the district with the Office of Civil Rights by a group of minority educators and parents. They decided not to join the complaint. They also decided not to endorse candidates for the April, 1979 school board elections, but encouraged individual members to get involved. A Coalition spokesperson explained the reason behind these various decisions.

We have a very delicate coalition, which is commited to improving people's attitudes toward integration, and we can agree on that. . . . If we start supporting candidates solely on their positions on desegregation, we'll lose some people and reinforce the board's belief that we are a radical group .. . The Coalition's role now will be less activist and more consciousness-raising. (Oregonian, 2/11/79, p. D3) 
The Coalition divided over which strategy to pursue. A small group of members, mostly white with occasional black participation, decided to pursue a monitoring role with the district over the implementation of the resolutions. Subcommittees were formed on student discipline, curriculum, teacher training, and housing. (CCSI Minutes, $3 / 22 / 79)$.

The Coalition began to fragment. People who wanted to work at the monitoring role became involved in that. People who wanted more action, legal or political, chose that route. (Interview, 6/11/80c) General attendance at meetings began to fall off and black participation lessened. Black Coalition members thought that more direct, political action was needed. Several filed a complaint with the Office of Civil Rights; others worked in the school board campaigns to defeat the incumbents. Still others became involved in organizing the Black United Front, a black advocacy group. One Black United Front/ Coalition participant described the difference in strategy between the Coalition and Black United Front. Coalition members were concerned about "doing things that would make the board feel good. The problem was that the board wasn't going to do whate we wanted them to until we got the leverage that would make a politician move" (Interview, 7/21/80). During this time, the Coalition wrestled with defining its role, strategies, and purpose as an organization. 
One Coalition member observed we were not at "the end of a process, the fight was just beginning" (Interview, $6 / 17 / 80 a)$. This time, however, the Coalition was not agreed on the course of action.

In sum, the initial impact of the Coalition's recommendations was:

1. Acceptance of nine recommendations and rejection of one, the pairing plan;

2. Board and district "working sessions" with Coalition representatives on resolutions;

3. Coalition pursues monitoring and educational role;

4. Black Coalition members and other members of the black community seek a more activist strategy to implement changes; and

5. Defeat of two incumberets who had supported the board's resolutions by two candidates who were supportive of the Coalition's plan.

\section{Long-Term Impact}

What was the impact on the formal rules and the educational practices of the school system that affect children at risk? Were there any changes in the network of activities at the federal, state, school district, and school levels that critically shape services to children? These criteria were used in an "applied research study concerning the effectiveness of independent child advocacy 
groups focused on the public schools" (Moore, 1980, p. 1). The coalition's impact will be analyzed in light of its effectiveness in improving services to children and altering the complex network of activities (Figure 6 ).

Educational Practices

Formal Rules

"Improve Services to Children"

COALITION :

- reduction in scattering

-initiation of evaluation and data gathering in areas of: suspensions achievement for A.T. students

- teacher evaluations

- reorganization of desegregation program

\section{Individuals:}

BLACK UNITED FRONT:

- Ireedom of choice for black children in schools -board appointment -N.E. middle school - short- and long-term resolutions on desegregation plan

-file OCR complaint

Network of activities

- electorai and appointive changes on school board

- Coalition and Black United Front set the stage for further changes, still in process

Figure 6. Policy impact of Coalition.

\section{Educational Practices}

The Coalition identified several major problems in Portland's desegregation practices which directly impacted children: the issue of "scattering," the fact of disproportionate suspension rates for minority students, and lack 
of achievement and other educational data on Administrative Transfer students for evaluation purposes of the program. In its recommendations, the coalition asked the district to respond to these problems. It made the board aware of the policy impact of its incremental decisions on desegregation. The Coalition dramatized the issues to the board and community with its visual presentation of the fact of "scattering"--thirty-nine buses drawing up every morning to King School which would scatter 451 children to thirtynine schools (Equity for the 30s, 1978, p. 44a, Figure 1). The school district took action on these issues. First, the school district now collects achievement data on black and white students, including the Administrative Transfer students. The district also provides suspension data by age, sex, and race so that evaluations can be made of the district's progress on discipline practices. (Interview, 1/81.) The Metropolitan Human Relations Commission has corducted an outside evaluation of district statiotics on suspension for the past two years (Analysis of Suspension and Enrollment Patterns Among Portland Public Schools, 1977-78 and 1978-79). In addition, the American Friends Service Committee initiated an education research and action project to provide case advocacy to families on school discipline practices as well as to monitor the district's record as regards minority children. Both of these community groups became involved in this issue as a 
result of the Coalition's research and recommendations on this issue. (Interviews, $6 / 20 / 80,7 / 21 / 80$ )

The Coalition's school pairing recommendation was designed to solve the problem of "scattering" which its research had documented. The board rejected the coalition's proposal because "the board does not believe that the pairing proposal of the coalition will either assure greater equity, increase inter-racial understanding, and improve educational quality, or further the District's integration program" (Board resolution $\mathrm{X}-6184,1 / 22 / 79$ ). However, the board did agree to "reduce substantially the number of receiving schools to which children from a particular neighborhood are transferred, while preserving appropriate latitude for parent choices of schools" (Board resolution $\mathrm{x}-6184,1 / 22 / 79)$ 。

The Coalition appointed a subcomrnittee to work with the district and board to develop a plan to reduce scattering. By April, 1979, the district had worked out standardized school assignments for King $I$ and Humboldt upper grade students. (Interviews, $8 / 27 / 80,9 / 8 / 80$ ) The superintendent reported on the progress to the board. The superintendent agreed with the coalition that scattering reduction is only viewed as an essential step, not the total solution of desegregation problems. However, "the standard and optional school assignments on the attached list will be implemented immediately by personnel of the district 
charged with responsibilities for school assignments and/or transfers" (Memo to Board of Education, 4/24/79, p. 1). In August, 1979, the superintendent again reported that "the number of receiving schools for new students has been reduced by $65 \%$ for 1979-80. That is 45 schools instead of the 168 schools identified by the Coalition for the 1977-78 school year" (Memo to Board, 8/29/79, p. 35). The number of children affected by these decisions were the 1,413 "voluntary transfer students," as well as the 351 black students for whom no grade levei was available (the involuntary transfer students) (Superintendent's response to Community Coalition for School Integration, 12/11/78, p. 3, Chart H). One school district staff person commented that in order to reduce the scattering "we ended up matching schools. We did more pairing than we thought we'd do" (Interview, 8/12/80).

One of the most significant changes was in the teacher evaluation procedures. Board resolution $\mathrm{x}-6121$ on standard of Performance in Mulit-Ethnic Education expanded the criteria on which a teacher's performance was based.

The competent teacher in subject with multi-ethnic dimensions includes appropriate multi-ethnic themes in lesson plans and instruction, including historical or other information as to cultures having significant impact on the world, nation, or community. (Board resolution $\mathrm{x}-6121,1 / 8 / 89$ )

This criterion was added in the spring of 1979 as part of teacher evaluations and continues to be used as of April, 
1981. This action was one of the more significant changes with long-reaching implications for district personnel, according to a district staff member (Interview, 12/10/80). There were also administrative changes as a result of the Coalition recommendations. Desegregation planning was centralized. The office of the Assistant superintendent for Community and Staff Development had a 50 percent increase in staff and acquired more authority to monitor and implement the desegregation program. The creation of the positions of Director of Desegregation Programs and a Coordinator of Student Transfer programs has resulted in better record-keeping and the machinery to evaluate the results of current desegregation efforts. (Interviews, $8 / 12 / 80,12 / 10 / 80)$

Network of Activities

Network of Activities refers to the forces that shape services to children.

For new laws and court decisions to be implemented whose purpose is to benefit children at risk, appropriate changes must take place in dozens of interrelated activities carried out by public officials and educators at the federal, state, school district and school levels. (Moore, 1980, p. 6)

The Coalition and, later, the Biack United Front, had a major impact in changing the political structure of the school district. In a related effort, two coalition members, through the filing of a complaint with the office of 
Civil Rights, tried to obtain its assistance changing the desegregation program. This section will discuss both these changes.

Much of the changes wrought in the educational practices began in the winter of 1979, but the defeat of two incumbent school board members in April, 1979 signaled the possibilities of more changes. The board chairman's reaction to the defeats highlighted the problems that lay ahead. "I'm sorry to lose the only minority member of the Board and the two women on the Board, . . the loss may hurt the Board's ability to deal with desegregation issues in a way that is credible to the minority community" (Oregonian, 4/4/79, p. 1). The women had both supported the board's rejection of the pairing plan. The remaining woman board member was recovering from a heart attack. The two new board members had supported the Coalition's work, but were not in agreement with the pairing plan. They did support the citizen process and the research findings on the problems in desegregation policy.

Most Coalition members and many of the board and school district staff believe the coalition's report contributed to the election of two new board members. Coalition members attribute the defeat of the incumbents to the awareness that changes were needed on the board. Movement on the desegregation plan would not occur without changes on the board. As one Coalition member explained, "We did 
not change the board policy on desegregation, but we did change the Board" (Interview, 6/11/80b). Newspapers keyed the incumbents' defeat to the issue of credibility. The school board has never before seriously challenged district desegregation policy, part of the Schools for the Seventies plan. Indeed its wholesale agreement (with one exception) with the Superintendent's rejection of the Coalition pairing proposal last winter caused it to lose more than a little face in Portland's black and white liberal community. Critics asked, Does a school board that relies so much on the superintendent's advice have credibility? This issue of school board credibility became the touchstone of the recent board election, and eventually catapulted the two new members of the board into office. (Willamette Week, 7/16/79, p. 9)

The Coalition laid the groundwork for the changes that vere to come. The Coalition expanded the range of policy options and paved the way for major policy shifts, observed one Coalition member. "We were the snowplow whose job it was to expand the level of discussion on the issue. We proposed radical solutions in order to get the Board to mäke moderate changes" (Interview, 7/14/80).

Office of Civil Rights

Complaint

With the death of the woman board member, another vacancy was created on the board in July, 1979. The appointment of a new board member became intertwined with two other events, the office of Civil Rights ruling and the emergence of the Black United Front.

In 1977, the office of Civil Rights received a letter 
of complaint from the Oregon Minority Educators Association, charging the district with seven violations of Title VI because of race discrimination. of the seven, three areas were scrutinized in the 1979 spring investigation: bias in the disciplining of black students, lower achievement scores for black students in Early Childhood Centers, and the excessive burden of desegregation borne by black students in Portland's student transfer-assignment program. In December, 1978, a companion complaint was filed by another educational staff member. Both persons were active in the Coalition. The Coalition had decided not to join the complaint process, but did meet with office of Civil Rights investigators and did supply its research findings to the investigation. Although the Coalition was not an official complainant, many members hoped that the federal government would intervene to force the board to change the district's desegregation plan (Interviews, 7/10/80, 7/24/80).

In June, 1979, the office of Civil Rights cleared the Portland schools of a bias charge in school desegregation.

Because busing in Portland is voluntary, the inequity we found is not violative under the law. Title VI of the Civil Rights Act limits our authority to review cases of discrimination only to places where there is a legal obligation to desegregate--in other words, where there is a court-ordered remedy to prior findings of discrimination. . . although we identified discrimination in Portland, it comes from a voluntary remedy to correct deficiencies in a system whose problems we hadn't even previously 
identified. And technically we just don't have the authority to act on it. (Interview with Virginia Balderrama, acting director of Region $x$, Office of Civil Rights, Willamette Week, 7/16/79, p. 9)

At its all-day planning session on June 30, 1979, the Coalition explored strategies for responding to the federal ruling. They asked an attorney to check the legality of the ruling and to see if it could be appealed. The Coalition also held a press conference and issued a public statement in response to the Office of Civil Rights ruling. The district was exonerated on a technicality; its plan was considered voluntary because it is not the product of a court order. HEW's letter of findings similarly vindicates the District based on the Department's interpretation of what constitutes 'gross' inequity--the measure for which is not clear in the letter.

This does not alter the fact that Black children continue to be discriminated against under Portland Public Schools desegregation program. (Press release, Community Coalition for School Integration, $7 / 12 / 79$, p. 1)

At the July 12, 1979 Coalition meeting, members discussed the feasibility of filing a complaint based on the Acts of Segregation which they had documented in their press release. They debated the question: "Can we be both cooperative and confrontational? The group view was that it is not smart politics to alienate ourselves from the district. Members were urged to report back to their own parent organizations to keep an active support of the Coalition alive" (Coalition minutes, $7 / 12 / 79$, p. 1).

This decision not to file a complaint was a critical turning point in the life of the Coalition because the 
blacks already had organized the Black United Front and had called for a boycott. The coalition, while recognizing the frustration that gave rise to the formation of the Front, could not decide whether to take a more ac:ivist stance. From this point, it was the Front which pushed for and achieved changes in the formal rules and educational practices of the district regarding its desegregation policy.

\section{Black United Front}

The Black United Front, on July 12, 1979, called for a boycott of the Portland Public Schools. The cochairperson explained the reasons behind this decision.

The ultimate indignity is that the Federal Government has done nothing, and apparently will do nothing, although it acknowledges that the District's prograin is discriminatory.

It is now up to Black parents to find solutions for themselves. . . become more involved and take a more active role in the education of our children. (Portland Observer, 7/19/79, p. 1)

The Black United Front (BUF) boycott demands reflected Coalition research and recommendations. The central issue was the scattershot busing of black students to white schools. School administrators claimed they had made significant progress in reducing the scattering since it was first exposed by the coalition, but boycott leaders called the approach "piecemeal" and claimed that a comprehensive plan was needed. (Oregonian, 7/29/79) 
Board Appointment

In the midst of the board's negotiations with the Black United Front, the board was also reviewing applicants for the vacant position. A board review panel recommended three white women for the post, which angered the black community even further (Portland observer, 7/12/79). There were five black applicants who were turned down. At the August 6, 1979 meeting, two blacks were added to the finalist list. The appointment was a critical one to the future direction of the district.

A majority formed by the added vote of this appointment, for instance, could give the district's desegregation program a radically new direction .. . But the fight for the majority-making vote--nothing less than a struggle for the control of school district policy--is on. Next week will tell which voting bloc--the traditionally pro-superintendent triumvirate or the newer, more critical members of the board=-will claim the balance of power in the future. (Willamette Week, 8/13/79, p. 1)

The candidacy of the black co-chairperson of the coalition and now a leader in the Black United Front boycott received endorsements from the Oregonian, Willamette Week, and the Portland Observer. (Portland Observer, 8/9/79) On August 13, 1979, before an audience of 200 citizens, the board appointed the Coalition co-chairperson and then heard its most veteran member immediately announce his resignation, creating another vacancy on the board. "It's a whole new ball game now," said one member of the audience as the reconstituted board began dealing with 
a response to the demands of the BUF U Oregonian, 8/15/79, p. F1). The new members (two elected, one appointed) plus the one member already supportive of the coalition, gave the new majority to the board. (Note: The additional vacancy on the board was not filled until after september, 1979, wher a young woman, active in city-wide youth affairs, was appoinced.)

On August 28, 1979, after lengthy negotiations between the Black United Front and the board, the school board voted to change the district's long-standing desegregation policy. An Oregonian editorial described the board's actions.

The School Board's plan responds positively to almost all published objectives of the coalition seeking to end isolation of blacks in public schools and fragmentation of black communities as a result of school policies.

Many of the remedies can begin without delay. For example, additional grades would be added at Eliot and Humboldt schools, which are early childhood centers; 351 black students who have no assigned middle schools will be able to choose among three in North and Northeast Portland; and parents whose children are in the district's Administration Transfer Frogram will be notified immediately that their children can return to the neighborhood primary, middle or high school.

Other changes that will tare longer: developing a comprehensive plan on all aspects of the integration program; planning and implementing one, and perhaps two; middle schools in Albina; and creating a broadly based monitoring group to serve as the voice of parents and children who may experience difficulty in receiving equitable treatment.

The central points, though, are that the school Board, by its actions, has acknowledged that the system has been unfair in the burdens blacks have had to shoulder in desegregation and has moved 
strongly--not in a token fashion--to remedy the injustices. $(8 / 30 / 79$, p. B6)

The black community responded by deferring the boycott to allow the district time to implement its decisions. As school opened, 300 black students left the Administrative Transfer program and returned to inner-city schools. (Oregonian. 9/5/79) The new policy, freedom of choice for black children, was greeted by black BUF members as the "beginning of a new day."

The formal rules had been changed, not by the persuasive tactics of the Coalition, but by the direct action tactics -- a proposed boycott--by the BUF. The coalition never resumed an active role with the district and in June, 1980 formally dissolved as an organization. It divided its remaining funds in a way that refiected the pluralistic diversity of the Coalition--half went to establish an dward for the new middle school students who wrote the best essay on integration, and the other half to the BUF to continue its work for educational change. (Coalition minutes, 6/3/80) 
CHAPTER VII

\section{FINDINGS AND CONCLUSIONS}

The purpose of this chapter is to discuss the applicability of the dissatisfaction theory of governance to a theory of educational policy intervention and the contributions of the finaings from this case study to a theory of policy intervention by citizen advocacy groups.

The problem statement which generated this study of policy intervention by a citizen's advocacy organization was "How do citizens intervene in the policy process to address perceived inequities?" It is recognized that there are others who can and do intervene in the policy process, but the focus of this study was on citizen action as an intervention strategy. The dissatisfaction theory of governance was the framework to analyze the developmental process of citizen dissatisfaction. What does this theoretical framework contribute towards an understanding of citizen intervention in the policy process?

\section{Dissatisfaction Theory of Governance}

The findings of the study support Iannaccone and Lutz's dissatisfaction theory of governance as a way of explaining the developmental process of citizen 
dissatisfaction with school desegregation policy in Portland from 1963 to 1977. (See Chapter I, Theory Framework, p. 26.) The school board, the legal authority, made its initial commitment to desegregation with its acceptance of the Schwab committee report and the initiation of Model Schools and Administrative Transfer programs. In 1970, the board and superintendent did alter elements of the desegregation plan with the Schools for the $70 \mathrm{~s}$ plan. That plan reorganized the district, converted schools in Early Childhood Centers, midale schools, and later, magnet high school programs. A critical part of reorganization was the establishment of Area Citizen Advisory Committees. There is some evidence that from 1965 to 1977 the board and district became closed to outside criticism and suggested changes in the desegregation programs. In 1969, two groups, the Model Cities Education Committee and the Citizens Committee for Better Schools, both urged the board to adopt a cross-busing plan and to give citizens a stronger role in the school decision-making process. The Area Citizen Advisory Committees can be seen as the board's response to their recommendations, but the ACACs did not have the degree of autonomy and independence that the community groups had recommended (Oregonian, 1/13/69, p. $16 ; 3 / 15 / 70$, p. 34$)$.

The failure of the tax levies and community opposition to middle schools made the district more dependent on policy 
changes that lay within its sphere of operations. The exception was the Early Childhood Centers, which did require citizen consent. The district conducted no evaluations of any of its desegregation programs. It relied on the area citizen advisory committees for community input. There is research by Gittell (1.979) and others (Boyd and Shea, 1975) suggesting that the presence of advisory committees serves to buffer school policy makers from parents' interest groups.

Gittell, for example, found that in those school systems in which mandated advisory committees were present, administrators restricted their contacts with the public to such groups. They defended this practice with the claim that such committees were, after all, representative of parents.

The buffering effect is not limited to the behavior of school administrators. Frieburger's (1976) study of school governance in a medium-size Massachusetts city revealed that school boards were three times more likely to consider presentations made by school advisory councils than voluntary parents' organizations. (Davies and Zerchykov, 1981, pp. 287-88)

The strongest indicator of the board and district's attitude toward external questioning of its desegregation policy was their reaction to community opposition over the Boise-King redistricting plan in June-July 1977. Newspaper coverage of the board meetings and interviews with board, district, and Coalition members for the purposes of this case study all attested to the feelings of anger and resentment on the part of the board, district, and community members alike. The community, in particular 
members of the black community, were upset that they had not been consulted before the policy was proposed.

Part of the ill feeling comes from the way the school board has handled the proposal. The plan was announced without consulting beforehand the community immediately affected or the community at large, both of which have much at stake in the vitality of city schools. (Oregon Journal, 7/20/77, Editorial)

The board and district's response was described in an Oregonian article:

In a comment interpreted by many as a slap in the face at dissenting citizens, the superintendent said he was 'very troubled when influential groups and individuals take exception to proposals based on the amount of criticism voiced rather than on the merits of the issue.' (Oregonian, 7/26/77, p. A1)

Some community members, later Coalition participants, said their motivation to join the coalition and to work for changes in the school desegregation policy stemmed from the board and district's disrespectful attitude, as evidenced at the July 25, 1977, board meeting. (Interviews, $6 / 12 / 80,7 / 21 / 80,7 / 24 / 80,7 / 25 / 80 b)$

In addition to the gradual closing of the system to external questions and criticism, two other factors need to be examined. These factors are the changes in the community's view of desegregation and demographic changes in the school-aged population.

The black community from 1965 to 1970 objected to the Model Schools program because it did not desegregate the schools. The implementation of the schools for the 
$70 \mathrm{~s}$ plan began to reduce the percentage of students in racially isolated schools. The percentage of black students in Albina grade schools after their conversion to Early Chilahhood Centers did decline, e.g., Humboldt grade school before conversion was $87 \%$ and after conversion was $51 \%$ (Oregonian, $11 / 12 / 78$, p. B1).

With the conversion of Albina grade schools to Early Childhood Centers, the practices of school desegregation began to impact the black community's view of desegregation. Early Childhood Centers may have improved the educational program at local schools and attracted some white students, but it cost the neighborhood their grade schools. There were incidents where black children could not attend the cent-rs because all the spaces for all local children were filled (Interview, 7/16/80a). Administrative transfer children told their parents of racial incidents on the bus, in schook, and after school at their receiving schools. Some parents became disillusioned with the Administrative Transfer program, as their children did not have successful experiences at these new schools. These were concerns of black parents as they comprised the majority of Administrative Transfer students. People began to question if busing was enough or if the quality of education at the receiving schools should not be examined.

This questioning of busing and the doubts about desegregation did not develop in isolation. Nationally, 
President Nixon had expressed opposition to busing and major media sources had covered the community of Boston's opposition to school busing. Throughout the country, blacks realized it was mainly they who got on the bus, not whites. Ironically, the Early Childhood Education Centers were attracting whites, but they were also a symbol to the black community in Portland of a school system that changed. black neighborhood schools, but not other areas of the city. As the office of Civil Rights noted in its 1977 report on School Desegregation in Portland, Oregon,

Another problem area rests with the continuing feeling among some members of the minority population that the burden of the desegregation process has been borne by minorities. (p. 14)

Between 1970 and 1977, the percentage of black students in the school system doubled due to a decline in white student enrollment. The major factor in that decline was that families were choosing homes in the suburbs rather than the city. The city population was increasingly elderly and young adults (Portland Mobility Survey, 1978). Budget constraints were another factor in the slow development of desegregation programs, especially midale schools and magnet high schools.

Another factor during the time period of 1970-77 was changes in the politics of the City of Portland. 1974 saw the election of a young mayor who was committed to citizen involvement in community development projects. 
Many people worked on his grass-roots election campaign and theri continued their involvement in neighborhood associations, community block grant projects, crime prevention, and economic development projects. There was a cadre of experienced organizers available to become involved in local issues (Interview, $4 / 18 / 80$ ).

All these factors contributed to the development of community dissatisfaction with the school desegregation policy. The next stage in Iannaccone and Lutz's theory on the formation of public opposition then leads to school board incumbent defeat. Next, how does public opposition form? It is at the point of intervention that the findings of this case study provide some insight into the conditions necessary for policy intervention by citizen advocacy groups.

The critical factors for the formation of the coalition and its subsequent intervention were the timeliness of the issue, available leadership, financial resources, and the potential of the group to generate support. David Truman (1950), an advocate of a system equilibrium model of government, "believes interest groups arise in an effort to establish a new homeostasis whenever the stability of a system has been disturbed. It is the disturbance that creates the interest group" (Education and Urban Policy, p. 156). 
Critical Issue and Timing

The disturbance was the community's reaction to the Boise-King redistricting plan. Up until June, 1977, the community believed that the board was following a desegregation plan, adopted in 1970, even if it affected black schools more than white schools. The Boise-king plan impacted the black community and some segments of the white community in several ways:

1. It was the first decision based solely on race. Jefferson was over $50 \%$ black, therefore, graduates of two primarily black grade schools would no longer be able to attend it.

2. The board did rot act according to its desegregation plan, which invelved ECECs, middle schools, and magnet high school prosrams.

3. The community reacted negatively to the manner in which the board handled the proposed policy change because the community was not asked for their opinion beforehand (Interviews, 6/12/80, 7/21/80, 7/25/80d, $8 / 20 / 80,9 / 15 / 80)$.

Another factor in motivating citizens to act is a crisis situation. One characteristic about schools is that information about school issues is not widely available. 
The kind of information which can mobilize a potential interest into an actual group only occurs in cases of institutional crisis in schooling - such as desegregation or school closures due to declining enrollment. Parental reactions tend to be after the fact, reactive and negative and episodic. (Davies and Zerchykov, 1981, p. 187)

The community perceived there was a crisis in policy-making. The board and district denied that it was a crisis and seemed surprised by the community opposition (Portland Observer, 7/21/77; Interviews, 6/2/80, 8/12/80, 8/27/80, $9 / 8 / 80)$. The board became defensive and finally, out of frustration, they asked several community groups to develop a better plan for Jefferson.

\section{Leadership, Resources, and Organizational support}

After the community dissatisfaction emerged, there were three factors which helped the coalition develop as an ad hoc, temporary group. First, the issue was important to several human relations, civil rights, and education advocacy groups in Portland. These organizations and their leaders were committed to act on the Boise-King proposal. Second, these organizations provided some financial resources and helped the coalition obtain its own funding. Third, these established groups gave credibility to the fledgling Coalition. They sent out the first mailing to approximately 500 people in August, 1977. Slightly over 100 people came to the first organizational meeting of the Coalition, 
September 1, 1977. The initial group of organizations attracted other organizations with power and influence plus some high status individual members (Coalition membership lists; Interviews, 6/I7/80b, 6/19/80b). The Coalition was able to generate support from various groups, ranging from the Chamber of Commerce to the PTA. Finally, it obtained its own staff and, through funding from the sity, county, school district, and private sources, sustained an eighteen-month research project.

In summaxy, the conditions that produced the policy intervention by a citizen's advocacy group were the timeliness of a critical issue, available leadership, financiai resources, staff, and support from organizations and people who had established credibility. This finding is consistent with other research which identifies the "backing of solidarity interest groups as a major source of power with which to induce social change" (Dubey, 1972, p. 231). A similar finding is that "money, time, criticalness of issue and coalitions were the conditions under which citizen participation could improve the responsiveness of an agency to the aims of particular groups" (May, 1971, p. 40). DIS/ID/STO/OS, the dissatisfaction theory, seeks to explain the political change and adaptation of the school organization due to citizen dissatisfaction. DIS is evidence of community changed dissatisfaction reflected in voting behavior leading next to incumbent school board 
member defeat (ID), followed within two years by involuntary superintendent turnover (STO) and outside succession (OS). The study of the Coalition finds that policy-makers who do not address citizen dissatisfaction with certain educational practices can lead to the community's readiness to intervene. The outcome of community intervention in Iannaccone and Lutz's model is change in the political process--incumbent defeat. Two researchers who applied the dissatisfaction theory to an analysis of 104 Southern California school board elections, concluded:

Based upon our findings, it appears that it is appropriate to equate democratic control over school poiicy with these episodes of electoral instability arising from voter dissatisfaction with incumbent school board members. Further evidence is needed to see if citizens change their orientation toward the schouls during the period immediately prior to the onset of an incumbent defeat period.

They hypothesize that "it may take a period of 10-16 years after demographic and ideological changes in a district, for school board member defeat and superintendent turnover to emerge. (Criswell and Mitchell, 1980, p. 209)

The community's expression of dissatisfaction during JuneJuly, 1977 did not lead directly to incumbent defeat, but to the formation of the coalition and their subsequent intervention in the policy process. To test the Criswell and Mitchell hypothesis on the Portland situation, it was fifteen years from 1962, when the NAACP first challenged the district to end "de facto" school segregation, until 1977 and the community dissatisfaction evidenced itself in its resistance to the Boise-King 
plan. Two years later, in ApriI, 1979, two incumbent school board members were defeated. The Coalition challenged the board's desegregation policy and made the public aware that desegregation was a critical issue in the community. The board and district's creaibility was questioned in the process. The actions of the coalition focused public attention on the critical nature of the desegregation issue. It made the school board accountable for the policy impact of its desegregation decisions. The proximity of this public attention to the schcol board elections influenced the voting public to make some changes on the board.

The research of Criswell and Mitchell (1980) called for further evidence to identify when citizens change their orientation toward the schools. The actions of the coalition between 1977 and 1979 suggest that intervention by a community organization in the policy process may be an intervening variable in the stages of dissatisfaction. The Coalition was a critical factor in focusing public attention on the board which resulted in incumbent defeat. In the case of Portland, community dissatisfaction led to intervention which then resulted in voting behavior leading to incumbent board member defeat.

The coalition was successful as a citizen advocacy organization in several important ways, as discussea in previous sections. It mobilized people, financial resources, its own staff, other organizations, and the media. 
The lack of these elements is a serious constraint to most citizen organizations. As one reseärcher observed, "resource-poor groups are unlikely to secure the control they need over resources sufficient to alter the pattern of benefits that they receive from the political system" (May, 1971, p. 46).

Not only was the Coalition able to build an organizational structure, but it had some success in raising the issue of school desegregation before the entire community. The Oregonian, the major newspaper in Portland, Oregon, had a two-week series on the issues the coalition addressed in its final report (November, 1978). All the local television stations as well as other newspapers gave the coalition's final presentations front-page coverage for over a month and television news editorials.

The Coaition was unable to change the desegregation policy in the manner it had planned. There were two major factors which served as constraints: reform model of change and the political environment.

\section{Theoretical Implications for Policy Intervention} By Citizen Advocacy Groups

One year after the Coalition's intervention, a Coalition spokesman, during an interview, commented:

We made one chief error. Once we delivered the report to the board, we did not plan for the struggle we needed to get it through the political 
process. But for all its lack of political savvy. . . the Coalition was no failure. It proved for the first time that blacks and whites could work together in Portland without the blacks' selling out. I think the Coalition's success is told in the rise of the Black United Front. (Willamette Week, $11 / 11 / 79$, p. A4)

The primary lesson to be drawn from the Coalition's intervention is that social reform strategies should not be used when the political and social realities call for radical political change. The Coalition is an example of the liberal reform model of social change. Coalition members looked to the past and saw the success of the Schwab committee, a board-appointed, blue-ribbon committee of the 1960s. Many of the Coalition members were from the Portland liberal establishment, like the Schwab committee, and had easy access to the school board and superintendent. For example, Schools for the City, a major participant in the coalition, had monthly meetings with the superintendent to discuss school-community issues. Many Coalition members also were active in the election of the liberal mayor in 1974. Both black and white members of the Coalition had used social reform techniques to accomplish political and social changes in Portland. They believed the same techniques would work in the desegregation issue.

The Coalition did not analyze the nature of the issue, its organizational constituencies, and the political environment in its policy intervention. The issue of school desegregation was and is a controversial policy. 
Nationwide, the media has provided the public with images of Boston riots, Los Angeles school board law suits opposing court-ordered desegregation, and buses burning in Pontiac, Michigan. Locally, the Portland school board and superintendent were proud of the desegregation plan which had not provoked white flight or public discussion. They were committed to its maincenance.

The Coalition did attract a diverse group of individuals and organizations, but failed to obtain support from the business and political constituences. Kirby (1973) found that the business community and mayor's support were critical factors in successful school desegregation plans in northern cities. Seattle school district, in changing its desegregation plan from voluntary to mandatory, received strong support from the downtown business community and the mayor's office. The Coalition did try to gain support from these two constituencies. However, the liberal mayor was conspicuously silent and the business community provided some financial assistance, but no strong, visible support.

Third, the Coalition misread the political environment for school desegregation. The Coalition knew who the cIitical actors were but did not apply sufficient political pressure to gain their support. The Coalition b $\epsilon_{\perp}$ ieved the political environment was liberal reformist and, thus, it relied on reformist tactics. Because it used only 
reform tactics, it was unable to convince the board to change the desegregation plan. Part of its failure lies in its unwillingness to use direct action tactics. The Coalition was just that--a coalition of people who had different reasons for wanting to change the desegregation policy. Some of the people were unwilling to consider direct action tactics: lawsuits or other more political forms of change. These were the people who had successfully accomplished change through reform tactics. others less successful with reform tactics urged confrontation and direct action. During the final days in November, 1978, as the Coalition struggled to make its final recommendations, an uneasy compromise was reached. The coalition called for an extensive school pairing plan which satisfied members' insistence on equity in the plan, but the plan was to be presented in the final report. There were no strategies developed if the research and recommendation approach, a reformist tactic, did not work. The plan called for radical changes but was delivered in a reformist style.

Local school district politics demonstrates the nature of political decision-making in Portland. The Coalition documented the inequity of Portland's school. desegregation plan in practice, but was unable to change it. It tock political and direct action intervention tactics to change the plan. The Black United Front, a 
black advocacy group, assessing the political environment in the city of Portland as racist and resistant to change, selected direct action intervention tactics. What the Coalition was unable to accomplish with its reform tactics, the Black United Front accomplished with a threatened boycott and use of the Coalition's research. The election and appointment of four new board members between April and September, 1979 was the other major factor contributing to the new board's willingness to change the desegregation plan.

A brief review of the events in school district politics since September, 1979 indicates how changes are made in educational policy. The Coalition's recommendation on school pairing was unacceptable because the white establishment did not want its children to be bused to black schools and they feared white flight with a two-way busing plan. Racism is not overt, but more subtie in Portland. In the spring of 1980, when the "new board" fired the superintendent, the business-professional establishment began a recall movement to remove the four members who made the termination decision. Although unsuccessful with the recall, the establishment forces formed a citizen committee to raise funds and to select appropriate candidates for the school board election in March, 1981. Two of their candidates were successful. The only black school board member, formerly of the Coalition, was reelected, 
but with less than fifty percent of the vote. Of the three other votes to terminate the superintendent, one member did not run for reelection, one board member was defeated, and the third member was not up for reelection and remains on the board. This election leaves only two of the new board and it seems as if the power of the board has returned to representation of the interests of the white businessprofessional establishment.

In summary, citizen acivocacy groups, to be effective, must be flexible about strategies and tactios, but more importantly mist analyze the political environment of the issue as to how ¿ecisions are made. If the citizen advocacy group is a coalition, it should decide early in its life whether to seek consensus on its intervention tactics or to pursue separate but mutually supportive tactics, which recognize the different viewpoints and strengths of its members. Lastly, as the coalition spokespersor indicated, the Coalition did not plan for the struggle to get its plan through the political process. Citizen groups

must be prepared for the process of change to take a long time and to have the endurance to accomplish its goals.

\section{Areas for Future Research}

One limitation to this study of a policy intervention by a citizen advocacy group was the time limit. This study covered a two-year period concluding with the board's 
decision to change the district's desegregation plan in September, 1979. There is a need for a longitudinal analysis of citizen advocacy intervention in the community change process. Such a study should evaluate the implementation of a decision, as well as the impact of the decision itself. For example, this study is unable to evaluate the long-term effects of the policy intervention which still is affecting the district. There have been a series of unintenced and intended consequences from the policy intervention: the new desegregation plan adopted in March; 1980, the firing of the superintendent in June, 1980, a boycott by the Black United Front in Spring, 1980, and a recall movement in the summer of 1980 . One indication of the reverberation of policy decisions is confirmed in the work of Crisswell and Mitchell (1980) who indicate that periods of electoral instability may last for eight years after community dissatisfaction emerges in the form of incumbent defeat.

In addition to a longitudinal study of specific policy intervention by citizen groups, a comparative study of citizen advocacy groups and intervention strategies would test the findings of this case study. A study of a variety of communities might reveal similar patterns or identify new attributes of successful intervention. Seattle, for example, which changed its desegregation program during the Fall of 1978, had substantial citizen 
intervention that included a successful boycott and a threatened court suit.

Citizen groups continue to be involved in the educational decision-making process, whether it is as monitors in the implementation of programs or as advocates for policy in its formation stage (Davies, 1978).

Cohen (1978) foresees the continuance of citizen advocacy organizations. Whether they are official or private, they will operate through existing channels of administration and control, using hearings, studies, litigation, and various decision-review processes to achieve their objectives.

Moore (1980) explains why advocacy groups will continue to be a factor in the educational decision-making process.

Child advocacy has developed as one response to breakdowns in the implementation of educational programs for children at risk. Advocates argue that implementation failures occur because laws are not vigorously enforced, because rigid organizations continue old habits in the face of new program ideas, because political pressures at various points in the implementation process dash the promise of new programs. They argue that reforms will improve services to children on a wide scale only when vigorous independent organizations press the educational system to carry them out at each point in the implementation process, in each important activity in the network of activities that shapes services to children. (p。7)

Further research is needed to test the relation of these various factors such as focus in advocacy, permanency, multiple intervention strategies to different kinds 
of organizations in varying poittical settings. A comparison of ad hoc, temporary self-initiated groups with mandated citizen groups is needed. Gittell (1978) observes that unfortunately there have been no sophisticated evaluations comparing the role of mandatory organizations under federal programs with šelf-initiated groups (1/78, p. 5). Davies (1978), Gittell (1978), and Moore (1980) all call for a strengthening of citizen-initiated, private, voluntary groups concerned about the schools.

It is clear . . that citizen-initiated community organizations are more likely to reflect the diversity of community interests than organizations mandated by government agencies. There is evidence that they are more aggressive and often more successful than government-sponsored community groups. They are more able than governmentinitiated groups to articulate community interests and place issues on the local political agenda. (Davies, 1/78, pp. 13-14)

This case study of the Coalition demonstrates some of the limits to effective policy intervention by a citizen advocacy group. However, citizen advocacy groups do intervene in the policy process. They can affect the policy outcomes. The Coalition is evidence of a specific kind of policy intervention. Other citizen groups intervening in other fields of interest need to be studied to see if they demonstrate the same pattern of intervention strategies. 
SOURCES CONSULTED

\section{Books and Articles}

Alinsky, Saul. Reveille for Radicals. Chicago: University of Chicago Press, 1946.

- Rules for Radicals. New York: Random House, 1971.

Allen, Robert I. Black Awaken ng in Capitalist America. New York: Doubleday and Co., 1969.

- Reluctant Reformers: Racism and Social Reform Movements in the United States. Washington, D.C.: Howard University Press, 1974.

Anderson, James E. Public Policy-Making. New York: Praeger Publishers, $1 \overline{975 .}$

Argyris, Chris. Intervention Theory and Method: A Rehavioral Science View. Reading, Mass.: Addison-Wesley, 1970.

Arnstein, Sherry R. "Eight Rungs on the Ladder of Citizen Participation." Journal of the American Institute of Planners 35 (July 1969):216-24.

Barber, James David. Citizen Politics: An Introduction to Political Behavior. Chicago: Markham Publishing Company, 1969.

Bell, Derrick A., Jr. "School Desegregation: Book Review." Harvard Law Review 92 (1979):1826-44.

Bellush, Jewel, and Hausknecht, Murray, eds. Urban Renewal: People, Politics and Planning. New York: Anchor Books, 1967.

Boyd, William I. "The Public, the Professionals and Educational Policy Making: Who Governs?" Teachers College Record 77 (1976):539-77.

Boyd, William L., and Shea, D. W. "Theoretical Perspectives on School District Decentralizaation." Education and Urban Society 7 (August 1975) :357-77. 
Brandt, R. M. Studying Behavior in Natural Settings. New York: Holt, Rinehart and Winston, 1972.

Caputo, David A., ed. The Politics of Policy Making in America. San Francisco: W. H. Freeman and Co., 1977.

Carmichael, Stokeiy, ana Hamilton, Charles V. Blacis Power. New rork: Random House, 1968.

Chin, Robert, and Benne, Kenneth D. "General Strategies for Effecting Changes in Human Systems." In Creating Social Change, pp. 233-43. Edited by Gerald Zaltman, Philip Kotler, and Ira Kaufman. New York: Holt, Rinehart and Winston, 1972.

Cloward, Richard, and Ohlin, Lloyd. Delinguency and Opportunity: A Theory of Delinguent Gangs. Glencoe, I11.: Free Press, 1960 .

Cohen, David. "Reforming School Politics." Harvard Education Review 48 (November 1978):429-47.

Crain, Robert I. The Politics of School Desegregation. Chicago: Aldine Publishing Company, 1968.

Crisswell, Larry W., and Mitchell, Douglas E. "Periodic Instability in School District Elections." Urban Education 15 (July 1980):189-215.

Cronin, Joseph M. The Control of Urban Schools. New York: Free Press, 1973.

Davies, Don. Citizen Participation in Education: Annotated Bibliography. New Haven: Institute for Responsive Education, 1974.

- "Citizen Participation in Schools: A Network of Illusions." Citizen Action in Education 5 (January 1978) : 1-4.

Davies, Don, and Zerchykov, Ross. "Parents as an Interest Group." Education and Urban Society 13 (February 1981) : 173-92.

Donovan, John C. The Politics of Poverty. Indianapolis, Ind.: Bobbs-Merrill, 1973.

Douglas, Marcia. Case study of Plans for Desegregating Portland Schools. Unpublished paper. Portland State University, 1978. 
Dror, Yehezkel. Design for Policy Sciences. New York: American Elsevier Publishing Co., 1971.

- Public Policy-Making.Re-examined. San Francisco: Chandler, 1968 .

Dubey, Sumati N. "Community Action Programs ana Citizen Participation." In The Practice of Social Intervention: Roles, Goals and Strategies, pp. 227-40. Edited by Frank M. Loewenber and Ralph Dolgoff. Itasca, Ill.: Peacock, 1972.

Dye, Thomas R. Understanding Public Policy. Englewood Cliffs, N.J.: Prentice-Hall, 1978.

Fantini, Mario. The Reform of Urban Schools. Washington, D.C.: National Education Association, 1970.

Fisher, Claudia. Case Study of the Development of a Community Coalition. Unpublished paper. Portland state University, November 30, 1977.

Frieburger, J. "A functional analysis of the policymaking role of a school board in response to demands made by associational groups, nonassociational groups, and individuals." Unpublished Ph.D. dissertation, University of California, Berkeley, 1976.

Gamson, William A. The Strategy of Social Protest. Homewood, Ill.: Dorsey, 1975.

Gittell, Marilyn. Participants and Participation. New York: Center for Urban Education, 1967.

- "Participation or Cooptation? A Look at Mandated Participation." Citizen Action in Education 5 (January 1978):5-6.

- Citizen Organizations: Citizen Participation in Educational Decision-Making. Final Report. NIE contract 400-76-0115, 1979.

Gittell, Marilyn, and Hevesi, Alan G., eds. The Politics of Urban Education. New York: Praeger, 1969.

Gordon, Edmund. "Factors in Desegregation and Integration." Equal Opportunity Review. Edited by Susan R. Nevas. New York: Columbia University, 1977.

Grant, Carl A., ed. Community Participation in Education. Boston: Allyn and Bacon, 1979. 
Guba, Egon. Toward a Methodology of Naturalistic Inguiry in Educational Evaluation. CSE Monograph Series in Evaluation. Los Angeles: Center for the study of Evaluation, 1978.

Hallman, Howard. "The Community Action Program: An Interpretative Analysis." In Power, Poverty and Urban Policy, pp. 285-313. Edited by Warner Bloomberg and Henry J. Schmandt. Beverly Hills: Sage, 1968.

Heflin, John F., and Douglas, Marcia. "School Desegregation: Portland Style." Paper presented at the Annual Meeting of American Education Research Association, Boston, Mass., April 10, 1980.

Iannaccone, Laurence. Politics in Education. New York: Center for Applied Research in Education, 1967.

- "Three Views of Change in Educational Policies." In Politics of Education, 76th Yearbook of the National Society for the Study of Education. Chicago: University of Chicago Press, 1977.

Iannaccone, Laurence, and Cistone, Peter J. The Politics of Education. Eugene, Ore.: ERIC Clearinghouse on Educational Management, 1974.

Iannaccone, Laurence, and Lutz, Frank W. Politics, Power and Policy. Columbus, Ohio: Charles E. Merrill Books, 1970 .

Iannaccone, Laurence, and Lutz, Frank W. Public Participation in Local School Districts: The Dissatisfaction Theory of Governance. Lexington, Mass.: Lexington Books, 1978 .

Jones, Charles 0 . An Introduction to the Study of Public policy. Belmont, Calif.: Duxbury, 1970 .

Katz, Michael B. Class, Bureaucracy and Schools. New York: Praeger, 1975 .

Kirby, David J.; Harris, Robert T.; Crain, Robert L.; and Rossell, Christine H. Political strategies in Northern School Desegregation. Lexington, Mass.: Lexington Books, 1973.

Levy, Frank. Northern Schools and Civil Rights. Chicago: Markham, 1971. 
Little, William A. Blacks in Oregon: A Statistical and Historical Report. Black Studies Center and the Center for Population Research \& Census. Portland,Ore.: Portland State University, 1978 。

Lindblom, Charles. The Policy-Making Process. Englewood Cliffs, N.J.: Prentice-Hall, 1968.

- "The Science of 'Muddling Through'." Public Administration Review 19 (1959):79-88.

Lofland, John. Analyzing Social Settings. Belmont, Calif.: Wadsworth Publishing Company, 1971.

Lutz, Frank W., and Iannaccone, Laurence. Understanding Educational Organizations. Columbus, Ónio: Charles E. Merrill, 1969.

MacColl, E. Kimbark. The Growth of a City. Portland: Georgian Press, 1979.

MacRae, Duncan. The Social Function of Social Science. New Haven: Yale University Press, 1976.

Marris, Peter, and Rein, Martin. Dilemmas of Social Reform. New York: Atherton, 1967.

May, Judith V. Citizen Participation: A Review of the Literature. Monticello, Ill.: Council of Planning Librarians, 1971.

Moore, Donald. Child Advocacy and the Schools. Summary Report. New York: Carnegie Corporation, 1980.

Moynihan, Daniel P. Maximum Feasible Misunderstarding. New York: Free Press, 1969.

Ornstein, Allan C. Race and Politics in School/Community Organizations. Pacific Palisades, Calif.: Goodyear Publishing Co., 1974.

ascal, Anthony. "What Do We know About School Desegregation?" Rand Series P-5777. Santa Monica, Calif.: Rand Corporation, January, 1977.

Rogers, David. 110 Livingston Street. New York: Random House, 1968 .

iRossell, Christine H. "School Desegregation and Community Social Change." Law and Contemporary Problems 42 (Summer 1978) : 133-83. 
Rothman, Jack. (1968) "Three Models of Community Organization Practice." In Creating Social Change, pp. 472-91. Edited by Gerald zaltman, Philip Kotler, and Ira Kaufman, New York: Holt, Rinehart and Winston, 1972.

- Issues in Race and Ethnic Relations. Itasca, I11.: Peacock Publishers, 1977. - Planning and Organizing for Social Change. New York: Columbia University Press, 1974.

Salisbury, Robert H. Citizen Participation in the Public Schools. Lexington. Mass.: Lexington Boolss, 1980.

Schatzman, Leonard, and Strauss, Anselm L. Field Research: Strategies for a Natural Research. Englewood Cliffs, N.J.: Prentice-Hali, 1973.

Simon, Julian L. Basic Research Methods in Social Science. New York: Random House, 1969.

Specht, Harry, and Pruger, Robert. "Assessing Theoretical Models of Community Organization Practice: Alinsky as a Case in Point." In Creating Social Change, Fp. 319-29. Edited jy Gerald Zaltman, Philip Kotler, and Ira Kaufman. New York: Holt, Rinhart and Winston, 1972 .

Spiegel, Hans B. C., ed. Citizen Participation in Urban Development: Cases and Programs. Washington, D.C.: NTL Institute for Applied Behavioral Science, 1969.

Sroufe, Gerald E. "Interest Groups and Public Poilis: A Status Report." Education and Urban Society 13 (February 1981):149-73.

Steele, Donald J. "Interest Groups As Seen By a Big City Superintendent." Education and Urban Society 13 (February 1981): $2 \overline{57-70}$.

Tucker, Harvey J., and Zeigler, L. Harmon. "The Myth of Lay Control." In Government in the Classroom, pp. 18-23. Edited by Mary Frase Williams. Proceedings of the Academy of Political science, Vol. 33, No. 2. New York, 1978 .

Webb, Eugene J.; Campbell, Donald T.; Schwartz, Richard D.; and Sechrest, Lee. Unobtrusive Measures. Chicago: Rand McNally, 1966. 
Wildavsky, Aaron. Speaking Truth to Power - The Art and Craft of Policy Analysis. Boston: Little, Brown and Company, 1979 .

Wiseman, Jacqueline P. "Toward a Theory of Policy Intervention in Social Problems." Social Problems 27 (October 1979):3-19.

Zeigler, Harmon, and Jennings, Kent. Governing American Schools. North Scituate, Mass.: Duxbury Press, 1974.

\section{Documents}

Federal

U.S. Commission on Civil Rights. Desegregation of the

Nation's Public Schools: A Status Report. Washington, D.C.: Government Printing Office, February, 1979. - School Desegregation in Portland, Oregon. Washington, D.C.: Government Printing Office, 1977.

\section{State}

State Board of Education. "Policy \#4171, Racial Balance in Public Schools." Salem, Oregon, March 22, 1964.

\section{Iocal Goverment}

Bureau of Planning. Portland Public Schools: 1950-1977. Portland, Ore.: Bureau of Planning, 1978.

Lycan, Richard; Pendleton, Pete; and Weiss, James. Residential Mobility Study for Portland, Oregon. Report for the Office of Planning and Development, Policy Development and Research Section, City of Portland, Oregon. Portland, Ore.: Office of Planning and Development, April 17, 1978.

Metropolitan Human Relations Commission. Analysis of Sispension and Enrollment Patterns Finong Portland Public Schools, 1977-78 and 1978-79. Report to the Commission and School District. Portland, Oregon, 1979 and 1980 . 
Portland Public Schools (Chronological sequence)

Committee on Race and Eaucation. Herbert M. Schwab, chairman. Race and Equal Education Opportunity in Portland's Public Schools. Portland, Ore.: Portland Public Schools, October 29, 1964.

Board of Education. "Statement on Portland Schools for the Seventies. Resolution No. 3553." Portland Public Schools. Portland, Oregon, Adopted March 23, 1970. (Mimeographed)

- "Attendance Area and Transfer Policy: Draft Resolution." Minutes of Meeting of school board, Meeting of June 6, 1977, Portland, Oregon. (Mimeographed)

Public Information Office. "Racial Integration Programs for Portland Public Schools: 1851-1978." Portland, Ore.: Portland Public Schools, 1978. (Mimeographed)

Office of the Superintendent. "Preliminary Superintendent Response to the Report and Recommendations of the Community Coalition on School Integration." Portland, Ore.: Portland Public Schools, December 11, 1978. (Mimeographed)

Management Information Service. 1979 Enrollment Report. Portland, Ore.: Portland Public Schools, 1979.

Office of the Superintendent. Memo to School Board: Statement of the Coalition at the Board Meeting of December 18, 1978. Portland, Ore.: Portland Public Schools, January 5, 1979. (Mimeographed)

Board of Education. "Board Resolutions of January 9 and 22, 1979." Minutes of Meetings of School Board. Portland, Ore.: Portland Public Schools, 1979. (Mimeographed)

Office of the Superintendent. Memo to Board of Education Portland, Ore.: Portland Public Schools, April 24, 1979 .

Board of Education. Minutes of Meetings of the Board, 1977-1979 and selected minutes of meetings from 19641970. Portland, Ore.: Fortland Public Schools. (Typewritten) 
Community Relations and Staff Development Department. "A Progress Report: Responding to the Report of the Community Coalition for School Integration." Report to the Board of Education. Portland, Ore.: Portland Public Schools, August, 1979. (Mimeographed)

Office of the Superintendent. "Superintendent's Annual Report to the Board of Education on Racial Balance: 1979-1980." Portland, Ore.: Portlanä Public Schools, 1980. (Mimeographed)

\section{Private Organizations}

City Club. "Racial Integration-Desegregation Issues in the Portland Public Schools." Portland, Oregon. May 30, 1980 .

- "Report on Model Schools Program of School District No. 1." Portland, Oregon, June 9, 1972.

- "Report on Problems of Racial Justice in Portland." Portland, Oregon, June 4, 1968.

- "Report on the Negro in Portland." Portland, Oregon, April 19, 1957.

Chairman of the School Board. Speech to City Club, "The State of the Schools." Portland, Oregon, December 29, 1978. (Mimeographed)

Community Coalition for School Integration. Equity for the 80s: A Report to the Board of Education. Portland, Oregon, November 27, 1978 .

- Letter file. Metropolitan Human Relations Commission, Portland, Oregon, 1977-79. (Typewritten)

- Minutes of Meetings, Portland, Oregon, 1977-79. (Typewritten)

- "Statement to the Board of Education: Response to the Superintendent." Portland, Oregon, December 18, 1379. (Mimeographed)

- "Statement of Position on Boise/King Redistricting Plan." Portland, Oregon, December 15, 1977. (Mimeographed)

League of Women Voters. "A Study of Local School Advisory Committees in School District \#1: Bring the Administrative Decision-Making Process Closer to Parents." Portland, Oregon, March, 1978. (Mimeographed) 
Model Cities Education Committee. Education Report. Portland, Oregon, January, 1969. (Mimeographed)

Schools for the City. "Area Citizen Advisory Committees After the First Five Years: A Study of the Years, 1970 to 1975, and Recommendations to Portland School District \#1." Portland, Oregon, May 19, 1976. (Mimeographed)

Television

KGW-TV. Transcript of Floyd McKay editorial. Evening News, Portland, Oregon. January 23, 1979. (Typewritten)

Legal Material

Brown V. Board of Education of Topeka, Kansas, 347 U.S. 483 (1954)

Economic Opportunity Act. U.S. Congress, Public Law 88-452, 88th Congress, 2nd Session, 1964.

Newspapers

Oregon Journal: April 20, 1962; June 8, 1977; July 20, 1977; July 26, 1977.

Oregonian: October 11, 1962; June 25, 1963; July 5, 1963; March 1, 1966; August 20, 1968; January 8, 1969; January 13, 1969; January 16, 1969; April 2, 1969; June 24, 1969; February 3, 1970; March 5, 1970; March 6, 1970; March 15, 1970; March 10, 1970; September, 29, 1971; May 24, 1972; April 3, 1977; June 21, 1977; Juily 7, 1977; July 15, 1977; July 23, 1977; July 24, 1977; July 26, 1977; July 11, 1978; November $12,15,16,18,20$, and 24, 1978; December 19, 1978; January 23, 1979; February 1, 1979; Februidy 11, 1979; April 4, 1979; August 15, 1979; and Fùsust 30, 1979 .

Portland Observer: July 21, 1977; July 28, 1977; August" 18, 1977; December 21, 1976; July 19, 1979; and all issues January, 1979-September, 1979.

Willamette Week: April 17, 1978; December 11, 1978; December 25, 1978; July 2, 1979; July 16, 1979; August 13, 1979; and November 11, 1979. 


\section{Interviews}

April 18, 1980; June 2, 1980; Jure 10, 1980; June 11, $1980 \mathrm{a}, 1980 \mathrm{~b}, 1980 \mathrm{c}$; June 12, 1980; June 16, 1980a, 1980b; June 17, 1980a, 1980b; June 18, 1980a, 1980b; June $19,1980 \mathrm{a}, 1980 \mathrm{~b}, 1980 \mathrm{C}$; June 20,1980 ; July 8, 1980; July 10, 1980; July 14, 1980; July 16, 1980a, 1980b; July 17, 1980; July 21, 1980; July 23, 1980; July 24, 1980; July 25, 1980a, 1980b, 1980c, 1980d; July 30, 1980; July 31, 1980; August 6, 1980a, 1980b, 1980C, 1980d; August 7, 1980; August 11, 1980; August 12, 1980a, 1980b; August 20, 1980; August 26, 1980; August 27, 1980; September 3, 1980; September 8, 1980; September 15, 1980; September 16, 1980; September 21, 1980; September 19, 1980; September 30, 1980; october 6, 1980a, 1980b; December 10, 1980. 


\section{APPENDIX A \\ INTERVIEW GUIDE}

What were the events that led to the formation of the coalition?

Why did a coalition form in the summer of 1977?

How did it become a coalition?

What was the goal of the coalition?

What were the specific complaints of the black community about Portland's desegregation effort?

What strategies did CCSI adopt to change the situation?

How were these strategies selected?

What other strategies were considered?

How would you characterize your role in CCSI?

Activist

Advocate

Coalition Builder

Agitator

Researcher

Broker

Fact-Gathering Analyst

Negotiator

Facilitator

*other: Please talk about what you did. 
In your opinion, ẩä CCSI have support of community groups? If so, which ones? How did they demonstrate their support?

Were there others who were not supportive? If so, how did they not show support?

What was your view of school board members on the issue of school desegregation in 1977 when CCSI began? Did your view change during life of CCSI? If yes, when and why? What was new view?

What was your view of school administration (central) on issue of school desegregation in 1977? Did your view change? If yes, why and when? What was new view?

Which constituency or community group (S) was CCSI trying to help?

How do conflicting groups work out their different interests in Portland?

Was the CCSI a special interest group or representative of more general community concern - i.e. public interest?

When the coalition made its inal report to the school board 12/78 and major recommendation on school pairing was not accepted, what direction did CCSI take? 
What were the critical events in the life of the coalition?

Is there anything that I have not asked you that you think is very important to know about the coalition? (success, failure, contribution, lasting impact) 


\title{
APPENDIX B
}

\author{
INFORMED CONSENT RELEASE
}

$I$, , hereby agree to be interviewed in the dissertation research on the role of citizen advocary groups in educational policy-naking specifical1:, the Community Coalition for School Integration. This research project is being conducted by Patricia $J$. Rumer, doctoral candidate in the School of Urban Affairs, Portland State University.

I understand that the study involves a discussion of the events during the life of the Coalition and my view of them. It has been explained to me that the purpose of the study is to learn how citizen advocacy groups can intervene to change or affect the implementation of specific educational policies in local school districts, and second, to assess the effectiveness of such an intervention.

I may not receive any direct benefit from participation in this study, but my participation may help to increase knowledge which inay benefit others in the future. Patricia J. Rumer has offered to answer any questions I may have about the study. I have been assured that all information I give will be kept confidential and that the identity of all subjects will remain anonymous.

I have read and understand the foregoing information.

DATE :

SIGNATURE

If you experience problems that are the result of participation in this study, please contact Richard Streeter, Office of Graduate Studies and Research, 105 Neuberger Hall, Portland State University, 229-3423. 


\section{APPENDIX C: KEY INTERVIEW QUESTIONS AND THREE MODELS}

OF COMMUNITY ORGANIZATION PRACTICE (Rothman, 1968)

\section{PRACTICE VARIABLES}

1. Goal categories of comunity action

2. Assumptions concerning community struciure and problem conditions

3. Basic change strategy

\section{INTERVIEW QUESTIONS}

-What was the goal of the Coalition?
- Why did a coalition form in the summer of 1977 ?

- What were the events that led to the formation of the coalition?

- What were the specific complaints of the black community about Portland's desegregation efforts?
4. Characteristic change tactics and techniques

5. Salient practitioner roles

6. Medium of change

- What strategies did the Coalition adopt? - Hor were these strategies selected? -What other strategies were considered?

-Provide examples of how change tactics were used.

-After January, 1979, what direction did the Coalition take?

- How would you characterize your role in the Coalition?

7. Orientation toward power structure

- Did Coalition have support of community groups? If yes, which ones? How did they demonstrate their support? Were there others who were not supportive? If so, how did they not show support?

-What was your view of the schooi board members in 1977 and then in 1979? View of school adminstration?

- Which constituency or community group was the Coalition advocating for?

definition of the community client system or constituency

9. Assumption regarding interests of community subparts

10. Conception of the public interest

11. Conception of the client population or constituency

12. Conception of client role
-How do conflicting groups work out their different interests in Portland?

- Was the Coalition a special interest group or representative of more general community concern, i.e., the public interest 
APPENDIX D

CHRONOLOGY OF COALITION ACTIVITIES: September 1977 to September 1979

\begin{tabular}{|c|c|c|c|c|c|c|c|}
\hline \multirow{2}{*}{\multicolumn{2}{|c|}{ PHASE I: }} & Aug. 177 & Sept. $\cdot 77$ & oct. 177 & Nov. 177 & Dec. 177 & Jan. 178 \\
\hline & & $\begin{array}{l}\text { Decision to form } \\
\text { broad-based } \\
\text { Coalition }\end{array}$ & $\begin{array}{l}\text { Organization of } \\
\text { of Coalition }\end{array}$ & $\begin{array}{l}\text { Locate funds. } \\
\text { School give } \\
\text { access to data }\end{array}$ & $\begin{array}{l}\text { Staff hired } \\
\text { Community } \\
\text { forums }\end{array}$ & $\begin{array}{l}\text { Office opens } \\
\text { Recs. to board } \\
\text { on Jefferson }\end{array}$ & $\begin{array}{l}\text { Board acceptance } \\
\text { of cCSI recs. }\end{array}$ \\
\hline \multirow[t]{4}{*}{ PHASE } & II: & Feb. 78 & March 78 & April ' 78 & May'78 & June 78 & July 78 \\
\hline & & $\begin{array}{l}\text { Research begins } \\
\text { on deseg. issues } \\
\text { Media focus on } \\
\text { forums }\end{array}$ & $\begin{array}{l}\text { CcsI report: } \\
\text { findings of } \\
\text { forums } \\
\text { Private fund- } \\
\text { raising }\end{array}$ & $\begin{array}{l}\text { Extend deadline } \\
\text { of final report } \\
\text { to } 11 / 78 \\
\text { Outside firm to } \\
\text { do survey }\end{array}$ & $\begin{array}{l}\text { 1st CCSI party } \\
\text { Board-CCSI } \\
\text { meetings }\end{array}$ & $\begin{array}{l}\text { Mtgs. with city } \\
\text { council \& county } \\
\text { comnissioners }\end{array}$ & $\begin{array}{l}\text { Discussion of } \\
\text { legal issues } \\
\text { Survey results }\end{array}$ \\
\hline & & Aug. 18 & Sept. $\cdot 78$ & Oct. $\cdot 78$ & Nov. 78 & Dec. 78 & Jan. 79 \\
\hline & & $\begin{array}{l}\text { Write-up of } \\
\text { deseg. options }\end{array}$ & $\begin{array}{r}\text { Second series of } \\
\text { forums }\end{array}$ & $\begin{array}{l}\text { community } \\
12 \text { part series } \\
\text { on CCSI \& deseg. } \\
\text { in Oregonian }\end{array}$ & $\begin{array}{l}\text { CCSI final vote } \\
\text { on recommen- } \\
\text { dations }\end{array}$ & $\begin{array}{l}\text { CCSI presenta- } \\
\text { tion to Board } \\
\text { Superintendent } \\
\text { response }\end{array}$ & $\begin{array}{l}\text { Board rejection } \\
\text { of school pairing } \\
\text { cCsI office closes } \\
\text { loss of staff }\end{array}$ \\
\hline \multirow[t]{2}{*}{ PHASE } & III: & Feb. 79 & March 79 & April 179 & May '79 & June 179 & July'79 \\
\hline & & $\begin{array}{l}\text { Reorganization } \\
\text { of CCSI } \\
\text { OCR complaint } \\
\text { filed } \\
\text { CCSI response } \\
\text { to Board }\end{array}$ & $\begin{array}{l}\text { CCSI subcommit- } \\
\text { tees appointed } \\
\text { to work with } \\
\text { board district } \\
\text { ccsI visit to } \\
\text { seatile }\end{array}$ & $\begin{array}{l}\text { HEW visit with } \\
\text { CCSI } \\
\text { Decline in black } \\
\text { participation in } \\
\text { CCSI }\end{array}$ & $\begin{array}{l}\text { School board } \\
\text { incumbent defeat } \\
\text { End of CCSI/ } \\
\text { board meetings }\end{array}$ & $\begin{array}{l}\text { CCSI planning } \\
\text { workshop } \\
\text { OCR Decision }\end{array}$ & $\begin{array}{l}\text { Appointment of } \\
\text { Coalition co-chair } \\
\text { to school board } \\
\text { Board member resigns } \\
\text { BUF call for boycott } \\
\text { CCSI response to OCR }\end{array}$ \\
\hline
\end{tabular}

August and September, 1979

CCSI statement to school board re: need for action on desegregation

Board action: shor' \& long-term resolutions 


\author{
APPENDIX E \\ "WHAT IS THE COALITION?" JUNE 1978
}

PURPOSE OF THE COMMUNITY COALITION FUR SCHOOL INTEGRATION:

1. Identifying common concerns in the Portland community regarding school desegregation.

2. Developing the kind of policy recommendations that would enhance equal educational opportunity and thereby maximize the potential of every student to achieve.

MEMBERSHIP: 104 indivisuals and 38 organizations representing parents, teachers, students, administrators, businessmen, neighborhood associations, churches and other civic groups.

HISTORY: The Coalition was formed out of community opposition to proposed Portland school Board policy dealing with "racial imbalance" at Jefferson High School.

On July 25, 1977, the Board asked the NAACP, the

Urban League of Portland and the Metropolitan Human Relations Commission to develop alternative recommendations for addressing the problem of "racial imbalance" at Jefferson.

These three organizations extended an open invitation to any group or individual to participate with them in responding to the School Board's proposed policy.

It soon became apparent that a district wide examination of desegregation policy was necessary in order to adequately consider the problem of "racial isolation" at Jefferson. It had been 13 years since the blue ribbon study of the Schwab Committiet (1964).

The Coalition presented its findings on the Jefferson attendance area to the School Board on Dec. 15, 1977. (A summary is available.) In January, the Board acopted the Coalition's recommendation to drop the high school. redistricting plan for the Boise/King ara.

DISTRICT WIDE EXAMINATION OF SCHOOL DESEGREGATION: The Coalition held 15 COMMUNITY FORUMS to give information and hear the concerns of the citizens. A press conference detailing the results of the Forums was held on March 31 , 1978. (A summary is available.) 
The RESEARCH COMMITTEE is gathering information and studying these areas relevant to school desegregation in Portland:

1. History of School Desegregation Efforts in Portland

2. Analysis of Current Desegregation Efforts in Portland.

A. Programs

B. Legal Issues

C. Resource Allocation

D. Population and Housing Trends

E. Economic Trends

3. Analysis of School Desegregation in Other Cities

The Coalition is conducting a SURVEY of parents, students, teachers, and principals connected with the Administrative Transfer Program, Early Childhood Education Centers and High School Magnet Programs. A professional research firm will conduct interviews of parents and principals and analyze the results of all the surveys.

POIICY RECOMMENDATIONS: Plans and recommendations for school integration will be formulated within the coalition and presented to the School Board in November 1978.

FINANCIAL SUPPORT: The Coalition has received financial support from the Portland School District, City of Portland, Multnomah County, the business community and the individuals and organizations that make up its membership.

Coalition meetings are open. Call the office for information.

The following groups and organizations are members of the Community Coalition for school Integration:

ALBINA ACTION CENTER, INC.

ALBINA MINISTERIAL ALLIANCE

BOISE NEIGHBORHOOD ASSOCIATION

BRIDLEMILE SCHOOI P.T.A.

CENTER FOR URBAN EDUCATION

CHURCH WOMEN UNITED
CITIZENS FOR CHILDREN

CITIZENS FOR PUBLIC EDUCATION

COMMITTEE FOR QUALITY EDUCATION FOR ALI CHILDREN

CONCERNED CITIZENS OF ALBINA COMMUNITY

CONCORDIA COMMUNITY ASSOCIATION 
ECUMENICAL MINISTRIES OF OREGON

F IGHTBACK

HEALTH HELP CENTER, INC.

JEFFERSON DAD'S CLUB

KING IMPROVEMENT ASSOCIATION

IEAGUE OF WOMEN VOTERS

MARSHALL HIGH SCHOOI COMMUNITY COUNCIL

METROPOLITAN HUMAN RELATIONS COMMISSION

NATIONAL ASSOCIATION FOR THE ADVANCEMENT OF COLORED PEOPLE

NATIONAL CONFERENCE OF CHRISTIANS AND JEWS

NATIONAL COUNCIL OF JEWISH WOMEN

N.E. COALITION OF NEIGHBORHOODS

OREGON ASSOCIATION OF COLORED WOMEN'S CLUBS
OREGON MINORITY EDUCATORS

ORGANIZATION

OREGON SOCIALIST WORKERS

PARTY

PORTLAND ACTION COMMITTEE TOGETHER

PORTLAND ASSOCIATION OF TEACHERS

PORTLAND CHAMBER OF COMMERCE

PORTLAND COUNCIL P.T.A.

PORTLAND FEDERATION OF

TEACHERS

SABIN COMMUNITY ASSOCIATION

SCHOOLS FOR THE CITY

S.E. YOUTH SERVICE CENTER

STUDENT COALITION AGAINST

RACISM

THE URBAN IEAGUE OF PORTLAND

VANCOUVER AVENUE FIRST

BAPTIST CHURCH

WILSON HIGH SCHOOL ADVISORY COMMITTEE 